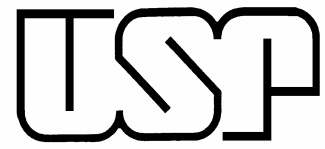

\title{
PROCESSO DE APRENDIZAGEM NAS PRÁTICAS URBANAS
}

\section{NAGÍRLEY KESSIN OLIVEIRA SALES}

Dissertação de Mestrado apresentada Faculdade de Arquitetura da Universidade de São Paulo

Para obtenção de Título de Mestre em Estruturas Ambientais

Área de Concentração Paisagem e Ambiente

Orientadora Profa. Dra. Catharina Cordeiro Lima

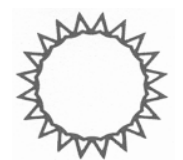

São Paulo

Novembro 2006 
Autorizo a reprodução e divulgação total ou parcial deste trabalho, por qualquer meio convencional ou eletrônico, para fins de estudo e pesquisa, desde de que citada a fonte.

e-mail: ngkessin@usp.br

Sales, Nagírley Kessin Oliveira.

S 163p Processo de Aprendizagem nas práticas urbanas / Nagírley Kessin Oliveira Sales. São Paulo: 2006

206p. :il.

Orientador: Catharina Cordeiro Lima

Dissertação de Mestrado - Faculdade de Arquitetura e Urbanismo da Universidade de São Paulo. Programa de Pós Graduação em Estruturas Ambientais. Linha de Pesquisa Paisagem e Ambiente.

Learning's process in the urban practices.

1.Favela 2.Participação 3. Desenho urbano 4.design comunitário 5. Assentamentos informais 6. Práticas alternativas 7.Arquitetura social.

CDU 711.585 
UNIVERSIDADE DE SÃO PAULO

Faculdade de Arquitetura e Urbanismo. Processo de aprendizagem nas práticas urbanas: documentos impresso e eletrônico. São Paulo.

\section{ERRATA}

Folha

Linha

Onde se lê

Leia-se 


\section{Universidade de São Paulo Faculdade de Arquitetura e Urbanismo}

Candidato: Nagírley Kessin

Dissertação: Processo de aprendizagem nas práticas urbanas.

Orientador: Professora Dra. Catharina Cordeiro Lima

A Comissão Julgadora dos Trabalhos de Defesa da Dissertação de Mestrado, em sessão pública realizada a .considerou o (a)
( ) Aprovado(a)
( ) Reprovado(a)

Examinador (a) Assinatura.

Nome

Instituição.

Examinador (a) Assinatura.

Nome

Instituição.

Presidente Assinatura.

Nome 


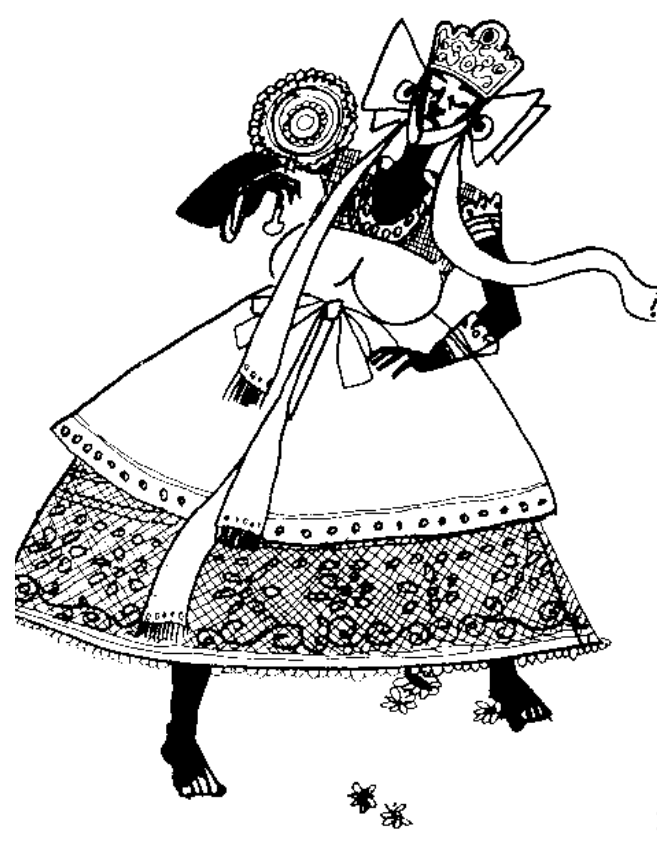




\section{A gênese da questão-problema}

“A desordem é só uma ordem que exige uma leitura atenta”

Carlos Nelson Ferreira dos Santos

\section{Uma parte...}

Em Salvador, o tempo tem seu próprio “tempo”, mais flexível, sem amarrações esquemáticas, à disposição da paixão de cada momento e não de planos pré-definidos. A exuberância cultural do soteropolitano obriga a qualquer um, saltar dos antecedentes lusitanos, ameríndios e angolenses, ao presente brasileiro. Uma paisagem inefável, Salvador é o ambiente, como uma lição sem aulas, em que toda a cidade é uma aula na qual nós queremos ficar em férias. A Baía de Todos os Santos derrama uma paisagem exuberante no colorido, nos aromas e na ginga que balança as folhas e dá cadência aos passos de seus praticantes surpreendendo-nos em seus contrastes de variedades.

Em verdade, foi um desafio realizar esta pesquisa descobrindo a história de Salvador que não foi passada a revista. Evidente que não pude captar, nesse curto espaço de tempo, todos os detalhes da misteriosa paisagem baiana, mas ajudada por amigos, com suas contribuições e com meu desejo ardente de realizar os estudos, com respeito, aqui está o resultado inicial de meu primeiro trabalho.

\section{E a outra,}

Nos tempos de estudante de Arquitetura, iniciei uma atitude pouco convencional em relação aos cânones da Arquitetura ao propor apenas diretrizes para uma sistemática de procedimentos operacionais de co-gestão ${ }^{1}$, ao invés de pranchas contendo desenhos coloridos. A primeira foi na disciplina de Planejamento Urbano III, com o objetivo de propor um projeto preliminar de reurbanização na favela de Bom Juá, localizada à beira da rodovia BR 101, saída sul de Salvador. Depois, na disciplina Planejamento V, apresentei as idéias iniciais de intervenção para um complexo turístico, mais tarde projetado pelos arquitetos Rosa Klias e André Sá, em uma área de uso diversificado entre visitação turística, local ritualístico da

\footnotetext{
${ }^{1}$ Co-gestão adotamos nesta pesquisa o significado de gerenciamento partilhado, em que as partes envolvidas são devidamente informadas com clareza, seus direitos, deveres e o papel de cada um.
} 
religião afro-brasileira - Lagoa de Oxum, e área de trabalho para as lavadeiras. A Lagoa do Abaeté é “uma lagoa escura arrodeada de areia branca”, uma paisagem caótica: de um lado apresenta um sistema biótico frágil, do outro vem sendo pressionada por uma forte especulação imobiliária tanto pelo mercado formal quanto o informal, cercando-a de todos os lados.

Nas duas propostas, apresentei um desenho menos detalhado, mas, indicações de procedimentos para a intervenção a partir da leitura partilhada da paisagem e, portanto, da compreensão que seus ocupantes tinham do lugar, reforçando o sentido de pertencimento e as transformações ocorridas, propondo soluções para um cenário futuro que desde já no presente devia ser melhorado, segundo a percepção daquelas pessoas. O projeto teve como produto propostas metodológicas de envolvimento dos usuários da Lagoa, ao invés de pranchas definindo a paisagem que deveria ser.

Depois de formada, iniciei meus trabalhos com muita dificuldade em escritórios de arquitetura. Precisava de uma compreensão do processo de desenhar, mais do que o simples objeto concreto final no papel. Qual o encadeamento lógico em seu processo? O que precisava para alimentá-lo? Quais os passos essenciais na constituição daqueles rabiscos, na sua complexidade infinita? O design como processo aconteceu a partir da convivência na obra e da troca com os operários no canteiro, transformando-o em um local permanente de aprendizagem, concretizando as linhas riscadas no papel, discutindo e redesenhando nas paredes ou na lousa que sempre costumo usar em minhas obras: a escola no canteiro.

Entre os anos de 1988 e 1989, trabalhei na implantação e construção de equipamentos urbanos, inicialmente as escolas de argamassa armada sob a coordenação do arquiteto João Filgueiras Lima. Com recursos da prefeitura de Salvador, a Fábrica de Equipamentos Comunitários - FAEC construiu escolas municipais públicas em áreas de assentamentos informais, com espaços entre 1.500 a 3.500 metros quadrados, espalhadas em todo o município de Salvador. Nos anos 90, em escala maior, os centros comunitários chamados Centros de Apoio e Integração Comunitária - CAIC, construídos pela CONCIC - Engenharia através da implantação de sua fábrica no município de Feira de Santana, a $100 \mathrm{~km}$ de Salvador, com o objetivo de implantar esses centros em todo o estado da Bahia. Esses projetos deveriam ser instalados nessas áreas informais que, invariavelmente, apresentavam falta de área comum destinada a manifestações culturais e atividades de lazer e esporte. Os equipamentos urbanos aterrissavam sem o conhecimento dos moradores e sua apresentação, que por poucas ou por nenhuma vez foram ouvidos. Não bastasse esse não consentimento, tais 
equipamentos muitas vezes foram colocados no único espaço aberto que a população utilizava como espaço de múltiplas funções.

Em 1997, com objetivo diverso que não a construção de uma edificação, fiz a inscrição no concurso público de idéias para intervenções em oito Favelas de Salvador, organizado pelo Instituto de Arquitetos da Bahia. Contrariei a situação tradicional de autoria de projetos: o desenho urbano de uma favela onde moravam 1.100 famílias, ocupando um espaço de 12,64 hectares. Essa experiência é o nosso objeto de estudo, a ser analisado na pesquisa.

Na Secretaria de Planejamento do Município de Salvador, entre os anos de 1999 e 2001, trabalhei no PEMAS - Programa Estratégico Municipal de Assentamentos Subnormais. O estado da Bahia, pela sua característica centralizadora, não delegava aos municípios sua gestão em questões próprias, a exemplo da política habitacional. O Banco Interamericano, defendendo uma postura menos centralizadora, promoveu o repasse de recursos para que os municípios se tornassem autônomos em relação à priorização de suas questões. Na mesma época, participei da coordenação de dois estudos para subsidiar a revisão do Plano de Desenvolvimento Urbano e Ambiental de Salvador - PDDUA - 2000: o primeiro sobre o uso e ocupação do solo, o segundo sobre o mercado informal imobiliário. Depois de realizar os dois estudos, na fase da revisão do PDDUA, entrei na equipe como colaboradora, mapeando as Áreas Especiais de Interesse Social - AEIS.

Na Companhia de Eletricidade da Bahia - COELBA, com coordenação geral da Diagonal Urbana, desenvolvemos o Programa de Intervenção para Comunidades Populares, em todo o município de Salvador. A seguir, ainda com a Diagonal e o poder público através da Companhia de Desenvolvimento Urbano do Estado - CONDER, realizamos um levantamento do perfil de duas comunidades nos Alagados, para uma futura intervenção no espaço, que impediria os sucessivos aterros naquela região - iniciados desde os anos quarenta - chamado Projeto Ribeira Azul.

Em 2000, participei na organização e construção do Plano de Desenvolvimento Sustentável de Itapagipe, apresentado no Fórum de Desenvolvimento Sustentável de Itapagipe em novembro do mesmo ano. Seu desenvolvimento foi promovido pela Articulação e Mobilização dos Moradores da Península de Itapagipe - CAMPI e pelo Núcleo de Articulação Interinstitucional de Itapagipe - NAI. 
Desse modo, as experiências com a cidade informal serviram para reforçar minhas observações, que serão colocadas como pressupostos nesta pesquisa acadêmica.

\section{E 0 todo...}

Não tenho nomes para agradecer, todos que passaram por mim, auxiliaram de alguma maneira para constituição deste trabalho. E ao lê-lo, reconhecerão suas contribuições, sejam pelas idéias, pelos sentimentos, ou através dos muitos sorrisos e lágrimas, mas acima de tudo pela coragem e resistência dos moradores de favelas - não é à-toa que o nome Favela (Cnidoscolus phyullacanthus) a esses assentamentos foi dado - o arbusto da Caatinga de porte médio que resiste às temporadas de maior seca, e, ainda alimenta...a muitos!

Cada um tem a sua parte, minha é apenas um enorme desejo de que este seja o início para virem mais e mais outras histórias de todos nós.

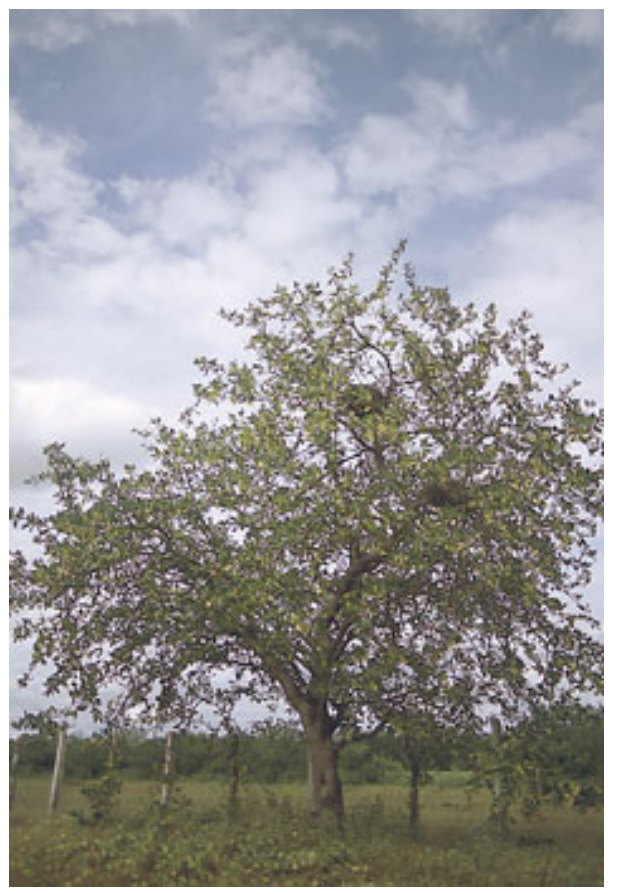

Xerófita que produz sementes comestíveis Remédios, lenha, madeira para construção, Forragem para animais.
Pelo Sol e seu glorioso esplendor Pela Lua que o sucede Pelo Dia que revela sua glória Pela Noite que o escurece Pelo Firmamento e sua magnífica estrutura Pela Terra e sua larga dimensão Pela alma, a proporção e a ordem que lhe foram dadas E por sua ciência do que é certo e talvez o que não é E é certo que quem a purifica terá sucesso

Rebelião Escrava no Brasil A história do levante dos Malês em 1835. João José Reis. Cia das Letras (2003). 
No Brasil, refletimos pouco; atuamos com vivacidade, exteriorizamos com simpatia, porém de forma indiscriminada; aceitamos mudanças com relativa facilidade, mas escasso senso crítico. Respondemos rapidamente à dinâmica de nossa realidade sócio-psico-econômica; rápida, mas nem sempre adequada e lucidamente.

Um "ir fazendo" que as vezes esquece ou substitui o "ir pensando". Jorge Whilheim 


\section{Resumo}

Esta dissertação de mestrado versa sobre algumas questões acerca de participação, tais como estratégia na educação e para a cidadania, da conquista de espaços públicos em suas transformações físico-políticos e qualitativo na gestão ambiental.

Trata-se da análise das experiências em assentamentos “subnormais” em que, apesar de terem sido trabalhos contratados pelo poder público, o arquiteto/pesquisador procurou planejar, desenvolver e xecutar os projetos através da visão de quem estava recebendo os investimentos. Entendendo que participar é poder tomar decisão em algum processo que irá mudar o destino de uma determinada situação, de forma espontânea ou não, mirando um futuro que desde já no presente deve ser melhorado. Assim é preciso que os sujeitos sociais tomem de informações preciosas, e provoque discussões num espaço múltiplo, diversificado no perceber e encarar as questões da paisagem relamente relevantes. Fruto da discussão, podem começar a aparecer soluções criativas, no processo de tomada de decisão que melhor atenda às necessidades e aos anseios da população em questão. Muitos foram os conflitos, principalmente, entre o arquiteto/pesquisador e o contratante/poder público, em virtude das diferenças de entendimento e abordagem, que se interpuseram na reconstrução de um espaço urbano em que, por lei, era obrigatório o envolvimento ou a participação do “usuário" para validar o próprio empréstimo. Entre essas diferenças estava a divergente concepção do que seria qualidade para a população, a que estariam destinadas os investimentos, constituídas de famílias de poucos recursos.

Também apresenta uma síntese metodológica no aprimoramento para a elaboração de projetos e obras de urbanização de favelas, atendendo não apenas a administração pública como também a população que recebe o investimento tendo como desafio a dimensão de uma educação não-formal, potencializando uma maneira ativa de participação popular que aponta, a partir da manifestação do coletivo, para uma qualidade de cidadania, que institui o cidadão como criador de direitos para abrir novos espaços, capaz de influenciar políticas públicas. 


\begin{abstract}
This master's degree dissertation addresses some issues regarding participation, such as education and citizenship strategies, in achieving public areas in their physical-political and qualitative transformation in the environment management.

The dissertation is refering to the analysis of experiences in "sub-normal" settlements where the architect/researcher strived to plan, develop, and execute projects from the perspective of those receiving the investments, although Public Power contracted their jobs, by understanding that participating is being able to make decisions in some process that will change, either spontaneously or not, the destiny of a given situation, targeting a tomorrow which should be improved as of today. Thus, social individuals need to gather worthy information and stimulate discussions within a multiple environment that is diversified in away to perceive and cope with actually relevant issues of the scenario. Resulting from discussions, creative solutions may start to come up in the decision-making process that better meet the needs and wishes of the target population. Many conflicts ensued between the architect/researcher and the contracting party, Public Power, because of the differences of understanding and approach that interfered in the rebuilding of an urban area where the involvement or participation of "users" was mandatory by law to validate the loan itself. Among these differences, there was the divergent conception of what should be considered as quality for the population for whom investments were designated and what was constituted of low-income families.

Also, what it is presents a methodological synthesis to improve project design and urbanization construction works in squatter settlements - favelas - by responding not only to public administration, but also to the population receiving the investment. The challenges include: the dimension of an informal education, and the empowerment of an active manner of popular participation that points to, from the population's manifestations, a citizenship quality, one which institutes the citizen as a rights designer to open new areas, enabled to influence public policies.
\end{abstract}




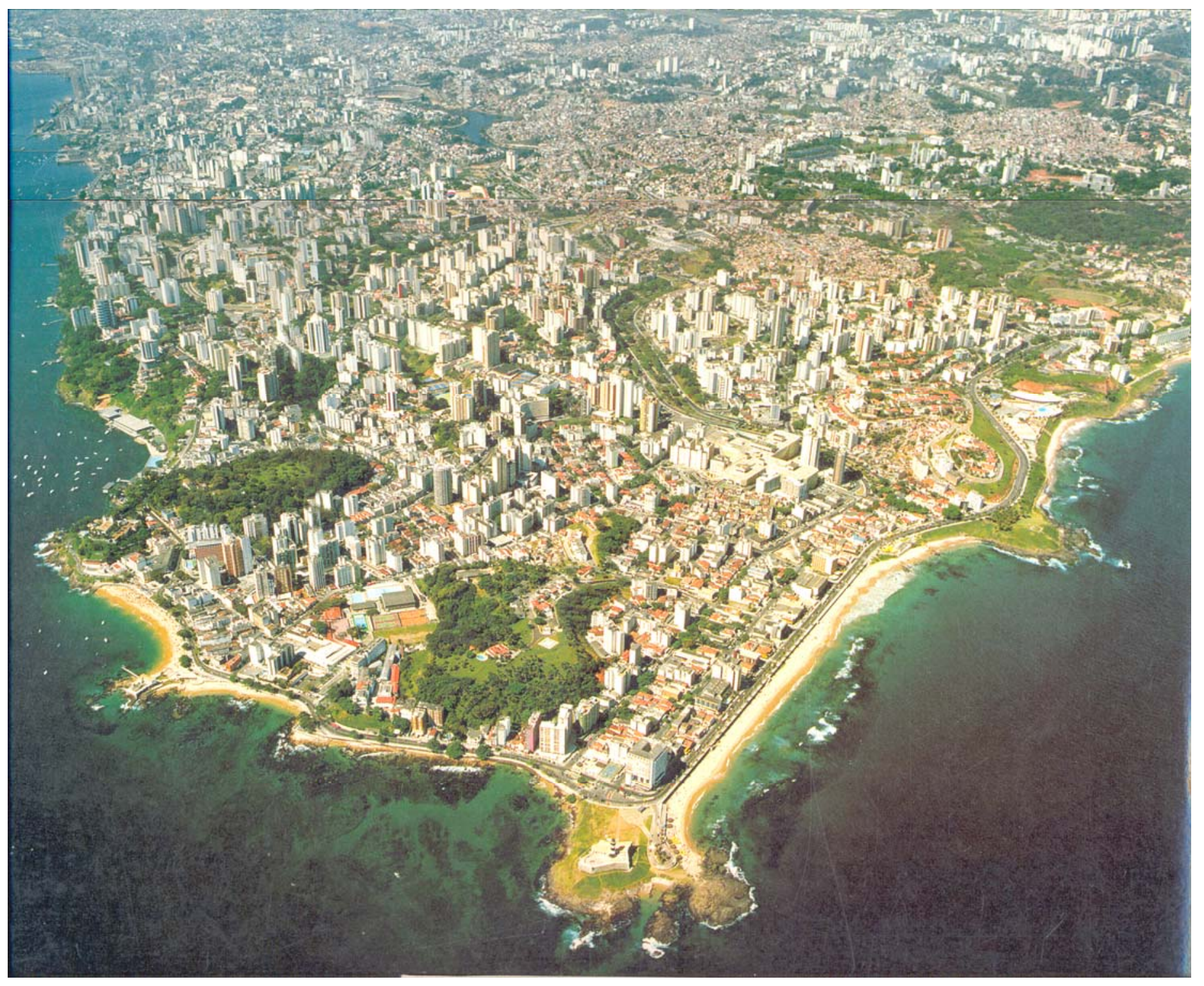


2. Referencial teórico: janelas da participação

2.1 Cenários e contradições

2.1.1 O espaço impessoal e o espaço inacessível Erro! Indicador não definido.

2.1.2 O movimento popular Erro! Indicador não definido.

2.1.3 O papel de cada um e a dificuldade em participar Erro! Indicador não definido.

2.2 Design com a comunidade Erro! Indicador não definido.

2.2.1 Community Design Erro! Indicador não definido.

2.2.2 Reconhecimento do termo e desenvolvimento da teoria ..... Erro! Indicador não definido.

2. 3 A matriz discursiva sobre participação Erro! Indicador não definido.

2.3.1 Os pressupostos para participar Erro! Indicador não definido.

2.3.2 Fragilidades e desafios Erro! Indicador não definido.

2.3.3 Etapas e Métodos Erro! Indicador não definido.

3. Construindo o objeto de estudo: a experiência Caranguejo 64

3.1 A lógica de ocupação de Salvador no contexto dos assentamentos espontâneos.

Erro! Indicador não definido.

3.1.1 A favela na cidade e a cidade na favela Erro! Indicador não definido.

3.1.2 Bairros periféricos feitos à mão Erro! Indicador não definido.

3.1.3 Histórico de ocupação e constituição da comunidade Baixa do Caranguejo Erro! Indicador não definido. 3.1.4 Elementos da paisagem Erro! Indicador não definido.

3.2 O concurso público e os documentos legais. Erro! Indicador não definido.

3.3 O projeto como processo de aprendizagem. Erro! Indicador não definido. 
3.3.1 O olhar de dentro da cidade Erro! Indicador não definido.

3.3.2 Relatos do cotidiano. Erro! Indicador não definido.

3.4 Considerações preliminares Erro! Indicador não definido.

4. Meditação crítica sobre a trajetória conceitual e a prática metodológica na Favela

Caranguejo 93

4.1 Conceitos pulverizados. Erro! Indicador não definido.

4.2 Impactos sócio-econômicos e físico-ambientais de políticas públicas. Erro! Indicador não definido.

4.3 Elementos para formulação de respostas Erro! Indicador não definido.

4.4 Pressupostos fundamentais Erro! Indicador não definido.

4.5 Visão de mundo e desafios propostos Erro! Indicador não definido.

4.6 O Cenário e a criação da comunidade futura Erro! Indicador não definido.

4.7 Considerações Erro! Indicador não definido.

5. Bibliografia 124.

6. Anexos. 137.

6.1 Resolução Normativa 181/95. 201.

6.2 Instrução Normativa No. 02/95 201. 


\section{Listas de Ilustrações}

Figura 1. Iansã Desenhos de Carlos Bastos tirado livro Jorge Amado Baía de Todos os Santos.................5A

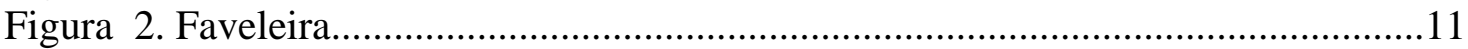

Figura 3. Foto aérea de Salvador 2001 Conder/Urbis..................................................17a

Figura 4. Vista da Cidade Baixa século XIX, foto de Mulock..................................87a

Figura 5. O cais de amarras, foto de Lindermann........................................................87a

Figura 6. Viaduto Itapagipe 1860 e Via Férrea, fotos de Mulock...............................87a

Figura 7. Trecho da Marinha do Porto de Salvador, foto de Schleir............................87a

Figura 8. Bairro do Rio Vermelho século XIX, foto de Linderman.............................87a

Figura 9. Igreja do Bonfin, inaugurada em 1754, foto de Mulock................................87a

Figura 10.Panorama da cidade feito do forte do Mar, século XIX, Ferrez...................87a

Figura 11.Mapa de 1851 de Carlos Weyl.................................................................87a

Figura 12. Mapa estrada de ferro escoar cana do recôncavo........................................87a

Figura 13. Mapa da cidade de Salvador do PDDUA..................................................89a

Figura 14. Fotografia aérea,1997 vista do subúrbio ferroviário, realizada José Carlos..........93a

Figura 15. Ortofotocarta 1973, serviços aerofotogamétrico Cruzeiro do Sul................................99a

Figura 16. Ortofotocarta 1976, serviço aerofotogamétrico Cruzeiro d Sul..................................99b

Figura 17. Fotografia aérea,1997 Favela Caranguejo realizada por José Carlos.....................99c

Figura 18. Fotografias do cotidiano da Favela Caranguejo fotos tiradas pelos moradores......113a

Figura 19. Fotografias do cotidiano da Favela Caranguejo fotos tiradas pelos moradores.....115a

Figura 20. Fotografias das reuniões tiradas pelos moradores e estagiário Eduardo.....................117a

Figura 21. Fotografias das reuniões tiradas pelos moradores figura do livro GODSCHALK,(1972).....119a

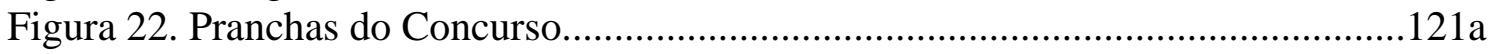

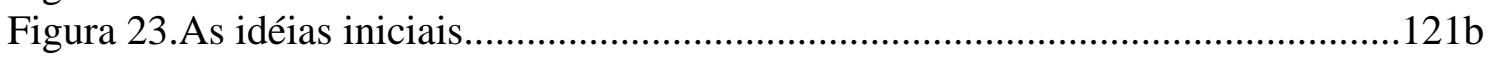

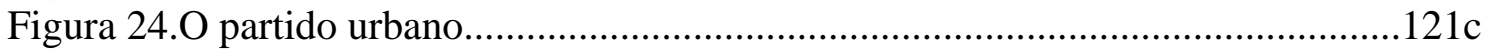

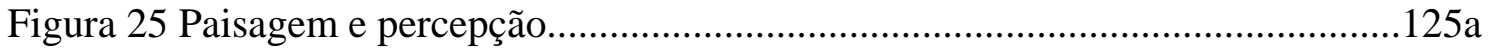

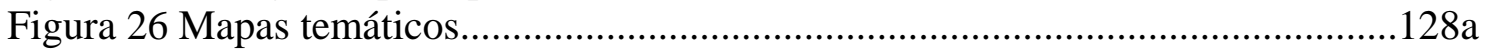

Figura 27 Integra Fragmenta, propostas de intervenção de Kroll (1986) e da Conder/Salvador..........146a

Figura 28. Monte Serrat desenhos de Carlos Bastos...........................................................176a

Figura 29. Mercado Modelo visto do forte São Marcelo, desenhos de Carlos Bastos............178a

Figura 30. Dique do Tororó desenhos de Carlos Bastos...................................................200a

Figura 31. Alexander e Figura 32. Halprin processo do design......................................208b 


\section{Introdução}

A identificação da questão-problema nesta pesquisa fecha um ciclo de questionamentos e análises da produção de uma pretensa arquitetura social e seus desdobramentos, na constituição de um espaço como lócus possível de discussão do coletivo, na escolha de uma cidade mais leal. Até onde deve interferir o arquiteto na forma de viver dos praticantes da cidade?

Trata-se da análise das experiências em assentamentos "subnormais” em que, apesar de terem sido trabalhos contratados pelo poder público, o arquiteto/pesquisador procurou planejar, desenvolver e executar os projetos através da visão de quem estava recebendo os investimentos. Muitos foram os conflitos, principalmente entre o arquiteto/pesquisador e o contratante/poder público, em virtude das diferenças de entendimento e abordagem, que se interpuseram na reconstrução de um espaço urbano em que, por lei, era obrigatório o envolvimento ou a participação do “usuário” para validar o próprio empréstimo. Entre essas diferenças estava a divergente concepção do que seria qualidade para a população, a que estariam destinados os investimentos, constituída de famílias de poucos recursos.

Na fase de experiência em urbanização de favela, o impasse tornou-se ainda maior, pois os projetos de urbanização representavam uma transformação mais integrada do espaço físico, implicando a introdução de novos serviços com novos custos, outras formas de apropriação e uso dos espaços. Concordando com SILVA (1999), essas transformações pressupunham atender à população que se apropriaria desse espaço, necessitando para isso adequar-se às novas condições do cenário futuro. E como seria possível sustentar os objetivos e os propósitos da intervenção, se não houvesse um entendimento muito claro e consistente do que seria qualidade por parte de quem a recebesse? Para o alcance dessas metas, o instrumento mediador seria uma participação eficaz. Segundo o poder público, isso já estava ocorrendo. Então, qual o sentido de toda esta pesquisa? Embora as intenções fossem boas, as ações participativas da comunidade favelada estavam distantes de promover algum resultado. Questionávamos, assim, de qual participação estar-se-ia falando? Quais os canais, as formas, e quando deveria acontecer? Essas são algumas das perguntas que fazem parte do escopo desta pesquisa, partindo-se da idéia de que não existe uma melhor solução para determinada questão. Cada problema tem um número infinito de caminhos para encontrar a resposta, e a participação vem reforçar a escolha da solução, pois estarão entendidas e fundamentadas na valoração da população beneficiada. 
O objeto teórico é o processo participativo de intervenções em assentamentos informais, e o objeto empírico em que se baseia a pesquisa é o experimento do re-desenho urbano na favela Baixa do Caranguejo, assim denominada por seus moradores. Favelas são assentamentos informais $^{2}$ que, irregulares do ponto de vista urbanístico, invariavelmente apresentam acesso deficiente para locomoção de pessoas e cargas e sistemas de transporte coletivo, além da falta de área comum destinada a manifestações culturais e atividades de lazer e esporte. As habitações são precárias, insalubres, com pouca ou quase nenhuma iluminação e ventilação natural. São ilegais, em que a situação do terreno não oferece segurança física nem legalização jurídica, embora a maioria dessas moradias pague taxas e impostos municipais.

Esse assentamento informal está localizado na periferia ou no subúrbio ferroviário do município de Salvador, de importância histórica para a cidade e para o país: foi o caminho dos engenhos no século XVI, substituído pela instalação da estrada de ferro em 1860, implantação das indústrias têxteis no início do séc. XX, e onde se perfurou o primeiro poço de petróleo, em 1939. Além disso, o lugar tem características físicas peculiares, a exemplo da falha geológica que lhe deu uma conformação de solo e topografia especial, e os recursos ambientais naturais disponíveis como o Parque São Bartolomeu, a borda recortada da baía de Todos os Santos, seus atrativos marítimos, e excelente potencial de exploração do turismo náutico. A área sob estudo comporta 1.110 famílias distribuídas em 12,64 hectares, sendo que a maior parte do solo foi criado pelos próprios moradores, através de aterros sucessivos, desde o final do século XIX. Sua cota em relação ao mar está apenas a trinta centímetros, o que a torna um desafio para soluções de drenagem. Anteriormente à implantação da estrada de ferro, ali se constituía área de mangue, com preamar e baixa-mar e três nascentes. Do ponto de vista geotécnico ambiental, essa jamais seria uma área apropriada para moradias, uma vez que sempre estará sujeita à influência das marés.

O propósito desta pesquisa foi o de explorar o processo de design ${ }^{3}$ como processo de aprendizagem, tanto para técnicos como para as comunidades moradoras nessas áreas, fundamentado no estudo de caso, com o objetivo de examinar a construção de um

\footnotetext{
${ }^{2}$ Adotamos, neste trabalho, o conceito de assentamentos informais. No capítulo 1, apresentamos outros conceitos mais corriqueiros como favela (slums), invasão, assentamento subnormal (substandard), assentamento invadido (squatter settlement), comunidades populares.

${ }^{3} \mathrm{O}$ design pode ser definido como sendo qualquer atividade com o propósito de dirigir um produto criado ou um processo que muda um ambiente ou uma organização (Reich, 1996). Outras questões podem advir, se considerarmos que na sociedade pós-industrial há uma inversão nesse processo que discutiremos neste trabalho. Para Sanoff, a diferença é que o design, como substantivo, é o produto final, o qual pode ser um objeto, um edifício ou uma paisagem, enquanto o design como verbo é um processo de tomar decisão.
} 
conhecimento partilhado entre as informações técnicas e a sabedoria popular, e as possibilidades de incorporar tal conhecimento a um projeto executivo de redesenho urbano e ambiental de favela. Através da presença de alguns representantes moradores - no universo total de 1.100 famílias - acompanhando, no período entre os anos de 1997 e 2000, encontros com o arquiteto/pesquisador, foram propostos temas variados que serão comentados nesta pesquisa.

Os objetivos específicos são o de compreender como os habitantes de áreas faveladas podem contribuir para elaboração de projetos, levando em consideração o ponto de vista da comunidade e qual o papel do arquiteto no processo. Ampliar a compreensão sobre processos participativos, e distinguir conceitos de participação em que se baseou a experiência aqui estudada e a metodologia a que obedeceu.

A hipótese é a de que a participação da comunidade é essencial para ampliar os recursos envolvidos em design, na medida em que essa participação tem uma repercussão maior na aplicação desses recursos. Portanto, quanto melhor a compreensão, maior o seu nível, e quanto mais cedo se der a participação, melhores e maiores os aspectos de satisfação dos moradores, seja na identificação de suas idéias no projeto, seja nas melhorias fundamentadas em sua própria realidade.

Segundo SELLTZ (1985), apenas uma pequena proporção de experiência e de conhecimento é colocada em forma escrita. Muitas pessoas, em sua prática cotidiana, vêem-se em situação que lhes permite observar os efeitos de ações e decisões alternativas referentes a problemas de relações humanas. A importância de sistematizar tais experiências é que na rotina de seu trabalho adquirem um conjunto de procedimentos que pode ter muito valor para auxiliar o cientista social a tornar-se consciente de importantes influências que atuam em qualquer situação que se poderá estudar.

Por outro lado, a participação da comunidade não somente vem sendo estudada nas mais diversas áreas, como também é incluída em grande parte nos projetos sociais e programas e políticas públicas. Contudo, tanto a leitura, como a vivência em situações em que é prevista a participação, evidenciam um grande hiato entre a intenção e a prática. Isso já é visível nas proposições iniciais dos projetos e trabalhos acadêmicos, nos quais não se distingue um conceito claro, uma definição de objetivos detalhados e uma metodologia conseqüente para seu alcance. O aclaramento desse conceito, a identificação em experiências práticas dos seus frágeis resultados, a indicação de uma metodologia mais adequada e a 
sistematização da experiência são elementos que justificam a realização do estudo ora proposto.

O trabalho empírico em reurbanizar uma área de assentamento informal - ilegal e irregular _, na periferia de Salvador-Bahia, entre os anos de 1997 e 2000, motivou esta pesquisa na pós-graduação, por ser a universidade o lócus de discussão permanente, oferecendo a oportunidade de reunir a teoria à prática. Fundamentado no cumprimento da Resolução $n^{0}$. 181/95 e Instrução Normativa $n^{0}$. 02, o processo relativo ao envolvimento dos moradores suscitou a reflexão teórico-metodológica, por ter tomado caminhos discrepantes em relação ao arquiteto/pesquisador e a instituição pública. O projeto, desenvolvido pelo arquiteto/pesquisador como processo, por ter dado um enfoque à participação de todos os envolvidos, respaldou-se na interpretação e compreensão dos escritos naquela resolução federal, no Manual de Fomento da Caixa, no Edital do Concurso e na metodologia do programa Favela Bairro do Rio de Janeiro. Como pesquisa, o processo foi ponderado sob algumas reflexões teórico-metodológicas, possibilitando, assim, além de identificar, justificar a ocorrência dos hiatos entre a prática e a teoria.

A presente pesquisa, portanto, sistematiza e sintetiza um experimento no espaço urbano coletivo, analisando-o e avaliando-o sob a luz do "estado da arte" em design participativo $^{4}$. O desafio nos coloca na categoria da educação não-formal e na maneira ativa de participação popular que aponte, a partir da manifestação do coletivo, a instituição do praticante da cidade como criador de direitos.

As etapas cumpridas para o alcance dos objetivos nesta pesquisa foram a sistematização do método de ação participativa na intervenção do espaço urbano da favela Caranguejo, a descrição do referencial teórico do design comunitário ${ }^{5}$, localização dos elementos principais do método Caranguejo na literatura, tais como conceitos, contextos e métodos.

No capítulo dois, a base teórica incorpora aspectos políticos, de orientação do professor Elenaldo Teixeira (2000; 2002) da Faculdade de Filosofia e Ciências Humanas da Universidade Federal da Bahia, bem como o Community Design, disciplina oferecida pela

\footnotetext{
${ }^{4}$ Disciplina obrigatória no College of Design da North Carolina State University ministrada pelo Professor Henry Sanoff.

${ }^{5}$ Community design foi um movimento internacional surgidos em meados dos anos 60, fundamentado na convicção plena de que a participação é crucial para a re-direção da formação de cidades. Tais pontos serão detalhados no capítulo 2, Referencial Teórico.
} 
North Carolina State University, com a orientação do professor Henry Sanoff (1990; 2000), esta última uma abordagem mais metodológica a partir de experimentos e reflexões críticas.

O capítulo três apresenta a descrição do objeto de estudo, com o relato circunstanciado quase transcrito da fala dos moradores, colocado propositadamente em linguagem diferenciada, tentando respeitar o vocabulário e a maneira como se expressam, para demonstrar a percepção que essas pessoas têm em relação às suas questões, constituindo um arcabouço de referencias mais de acordo com o local, e não mais do técnico.

Outros autores ainda contribuíram na constituição da base teórica da pesquisa, como Christopher Alexander (1975; 1985), John Turner (1977; 1972), João Bordenave (1994), Paul Davidoff (1965), Nick Wates (1997), Habraken (1986), Halprin (1969; 1974), Robin Moore (1998); Saul Alisnky (1972), Pedro Demo (1985; 2001), Paulo Freire (1990), enfocando a dimensão não apenas conceitual, como metodológica. A escolha de descrever primeiramente o experimento se deu para evitar a contaminação ao se estudar o referencial teórico, uma vez que não se planejou a participação dos moradores na experiência da Favela Caranguejo com base em alguma teoria participativa existente.

O capítulo quatro é um estudo comparativo do método descrito, de base empírica, em que se identificaram pontos comuns entre o experimento e a literatura, as diferenças, e as causas de terem ocorrido.

Por fim, analisa-se como a contribuição participativa daqueles representantes permitiu a ampliação nos ganhos da qualidade no planejamento, elaboração do projeto, no acompanhamento e na avaliação na hora de realizar as ações por parte da construtora e do poder público. 


\section{Referencial teórico: janelas da participação}

\subsection{Cenários e contradições}

Participar não é uma atividade nova. Em qualquer lugar no mundo, as pessoas usam construir suas próprias casas e comunidades sem assistência de especialista. Através de tentativas e erros, elas aprendem como podem organizar o padrão coletivo de vida e estar seguras em suas atividades de todo dia. O processo não apenas fornece a estrutura física para a moradia, como também os significados nos quais os indivíduos estão integrados à cultura de sua comunidade e participando de questões no âmbito social, econômico e político local.

Na visão superficial de alguns, a participação surgiu como novo conceito em função da democratização dos anos 60. No entanto, um olhar mais cuidadoso mostra que o envolvimento de cidadãos no planejamento oficial local data de 1870, nos Estados Unidos, e que as políticas de planejamento participativas dos 60 vieram da Europa, especialmente, via Inglaterra (WULZ, 1986). No final dos anos 60 e início dos anos 70, o termo participação passou a ter uma compreensão ampliada, quando alcançou diferentes campos, como sendo uma forma de pôr em prática a interação entre grupos (BEHESHTI, M.R., 1986). Nos anos 70, houve uma crescente aceitação do conceito, em virtude da visão de que a sociedade teria que se organizar para encorajar a liberdade e a independência do cidadão, e também proporcionar as ferramentas para esses cidadãos construírem uma eficiente participação em todo e qualquer aspecto da vida social, incluindo especialmente sua voz no processo de tomada de decisão.

A participação tem sido suporte de demandas políticas nos últimos trinta anos, por intermédio de políticos, especialmente para legitimar seu cargo como representantes do povo. Essa é uma posição mundial (WULZ, 1986). Para o setor público, a participação, de modo geral, é apresentada apenas para propor em público solicitação de doações, ou em campanha popular (SANOFF, 2000). Também se tornou questão de honra para alguns arquitetos. Entretanto, a participação, além de envolver algumas complexidades no processo de tomada de decisão, impõe diferentes formas de conceber as variedades do seu significado, levando para a discussão desse tema a própria construção desse conceito.

A falta de clareza, comum nessas situações, abre a possibilidade, aos políticos e arquitetos oportunistas, de utilizarem a participação como álibi para um aspecto negativo, 
mantendo seu tradicional papel como especialistas ou, em outras palavras, uma forma de abordagem autoritária para a tomada de decisão (SANOFF, 2000; WULZ, 1986).

Como prática comum, o técnico, ao ser chamado para elaborar um projeto de arquitetura, estabelece logo uma relação de respeito com o cliente. O profissional ouve o que seu cliente tem a dizer, e conduz essas descobertas de forma a traduzir seus desdobramentos no espaço físico futuro. Para o cliente de poucos recursos — "pobres” — esse entrosamento usualmente tem sido abortado. Nessa relação existe um trampolim passando direto do cliente para seu representante, o poder público. Os dados, ordenados ou não, e as informações retiradas da comunidade são imediatamente entregues àquela entidade, antes mesmo de serem transformados, com a comunidade, em conhecimento partilhado arquiteto/morador ou profissional/praticante da cidade.

Estão enraizadas nessa lógica as faces ocultas da pobreza, idéias preconcebidas que precisam ser elucidadas. Em geral, são definidos como pobres aqueles que não dispõem dos meios para atender à primordialidade de alimentação, segundo os requisitos nutricionais associados a um determinado padrão de consumo, nem às necessidades de educação, habitação, educação social, carências diversas, particularmente materiais, decorrentes de insuficiência de renda, já que o dinheiro é o meio privilegiado de compra de bens e serviços na sociedade capitalista. Como tema complexo, alguns estudiosos têm elaborado diversas metodologias para medir a pobreza, partindo de distintos parâmetros de renda ou linha de pobreza, abaixo das quais as pessoas são consideradas pobres. Para o Banco Mundial (BIRD), segundo esse raciocínio, cerca de 24 milhões de brasileiros, 17,4\% nos anos 90, estavam situados abaixo da linha de pobreza. Em relação ao Mapa da Fome, avalia que 22\% da população estão pobres (World Bank, Report \# 14323-Brasil, 1995).

O desdobramento leva a uma análise linear, cerceando a contribuição daquele que nada tem e limitando como solução apenas a melhoria da renda da família, e isso tem que ser feito, mas não apenas isso. Segundo essa lógica, o desenvolvimento da comunidade termina privilegiando apenas a obra física e as propostas produtivas, assim uma bateria de subprojetos responde a uma única exigência e é momentânea e conjuntural.

Por outro lado, essa bateria de projetos e subprojetos vem descrita nos programas sociais do governo, com objetivos e metodologia ou desenho de implementação expressados em uma legislação geral e uma regulamentação específica: Plano Diretor, Plano Estratégico para Assentamentos Subnormais, Estatuto da Cidade, Pró-Moradia, entre outros. 
Para sua execução, supõe necessariamente a relação (vinda de cima para baixo e, portanto, não há uma interação) de uma autoridade central com agentes realizadores. Nesses termos, os princípios que efetivamente pautam a ação desses agentes são a "legislação" e as “normas determinadas pela agência formuladora”. A complexidade mais abrangente das questões sociais raramente torna possível afirmar que “a implementação de um determinado programa tenha, na prática, atingido integralmente os objetivos e as metas previstas.

Mais difícil ainda é que um dado programa seja concretizado inteiramente de acordo com o desenho e os meios previstos por seus formuladores” (SILVA, 1999). Em outras palavras, entre os objetivos e o desenho de programas, tal como concebidos por seus formuladores originais, e a tradução de tais concepções em intervenções públicas, tal como elas atingem a gama diversa de seus beneficiários e provedores, há uma enorme diferença ${ }^{6}$.

Essa diferença ocorre pela visão linear sobre o ciclo de gestão das políticas públicas, ou seja, sobre o policy circle, que afere a eficiência dos programas ou políticas e seu grau de eficácia, presumindo-se unicamente com base no diagnóstico prévio essencialmente correto e no sistema adequado de informações na fase de formulação e, definição de metas, recursos e o horizonte temporal da atividade de planejamento, constituindo-se como uma das explicações pelo insucesso dos governos em atingir os objetivos estabelecidos no desenho dos programas, o fracasso na política e não no seu fluxo.

Isso leva a criação de novas propostas sem se ter a compreensão extensa dos fatos já ocorridos, sempre partindo de uma falsa idéia de que a informação está perfeita, a coordenação é perfeita, tem total controle, hierarquia, clareza de objetivos, enforcement de regras perfeitas e uniformes, linhas únicas de comando e autoridade, além de legitimidade política e consenso quanto ao programa ou política.

Na vida real, alguns estudos de situações concretas revelam um padrão muito distinto, em que prevalece a troca, a negociação e barganha, o dissenso e a contradição quanto aos objetivos, portanto, os agentes formuladores e implementadores das políticas públicas são levados a escolher determinadas estratégias de implementação pautadas muito mais por sua

\footnotetext{
${ }^{6}$ O relatório do NEPP - Núcleo de Estudos de Políticas Públicas da Universidade de Campinas - (SILVA,1999) é o resultado do contrato firmado entre o Governo Federal, através do PAGS - Programa de Apoio à Gestão Social no Brasil, e a Secretaria de Gestão do Ministério do Planejamento. Os estudos foram realizados pela Pontifícia Universidade Católica de Campinas. Os recursos para esse projeto vieram do próprio PAGS, que contou com apoio financeiro do BID e apoio logístico da UNESCO, necessários para sua concretização. O objetivo principal desse trabalho era o desenvolvimento de uma metodologia que avaliasse as ações de governo no campo social, com enfoque na implementação e no desempenho dos programas sociais e suas repercussões com os usuários ou beneficiários, e membros dos órgãos colegiados existentes em cada Programa.
} 
potencial aceitação do que por sua esperada eficiência ou efetividade. Portanto, a reação esperada dos agentes implementadores tende a ser um elemento decisivo na definição do conteúdo das políticas públicas em Estados federativos ${ }^{7}$, o que cria uma diversidade de cenário quase impossível de se acompanhar. Não bastasse isso, ao invés de controle, autoridade e legitimidade, verifica-se a ambigüidade de objetivos, problemas de coordenação intergovernamental, recursos limitados e informação escassa.

Identificados alguns hiatos nesse processo, poderemos apontar, por exemplo, que os especialistas e/ou formuladores de políticas, por não vivenciarem o ambiente em que pretendem intervir, enfrentam grandes limitações cognitivas devido à complexidade dos fenômenos sociais, sem contar, em nível operacional, a diferença entre os tempos, em que os prazos político-burocráticos são sempre para ontem e o tempo para a apreensão da realidade, trocas de informações e retro-alimentação do transcurso é lento e depende de uma série ilimitada de variáveis. Ademais, não há o reconhecimento de que os planos, as políticas e os programas são instrumentos que delimitam apenas um conjunto cerceado de cursos de ações e decisões que, teoricamente, os agentes deveriam seguir ou tomar. Portanto, nada garante, absolutamente, sua concretização na realidade. E ainda, a maioria dos formuladores expressa suas preferências individuais ou coletivas, que geralmente divergem daquelas da coletividade, o que significa deturpações de velhas tradições de uma democracia ainda bastante limitada.

Entretanto, como mais uma obscura face do problema, sendo a formulação de um programa - objetivos e desenho - um processo de negociações e barganhas de todos os lados, seu desenho final será obrigatoriamente aquele que tiver maior probabilidade de aceitação. Além disso, pelos seus antecedentes, já se sabe que suas peças não estão coesas e ajustadas, facilitando sua operação de forma até contrária aos objetivos do programa, ou seja, a diversidade de contextos de implementação pode fazer com que uma mesma regulamentação produza impactos inteiramente diversos em diferentes locais.

\subsubsection{O espaço impessoal e o espaço inacessível}

Neste estudo, considerou-se que existe uma fundamentação empírica conceitual na relação entre participação popular, assentamentos espontâneos através das ocupações, invasões, e movimentos sociais urbanos.

\footnotetext{
${ }^{7}$ Em que os Estados têm sua autonomia de desenvolver políticas e programas.
} 
Segundo CASTELS e BORJA (NEVES, 1985), esses movimentos são sistemas de práticas sociais contraditórias ou de encontro à ordem estabelecida, a partir de contradições específicas da problemática urbana, e as ações coletivas dessa população, enquanto praticantes da cidade, estariam destinadas a evitar a degradação de suas condições de vida; a obter adequações das novas necessidades, segundo seu próprio ponto de vista e não mais o da gestão pública.

Nesse sentido, a compreensão e a análise sobre as demandas, movimentos e mudanças sociais constituem-se numa importante forma de participação, alcançando melhor entendimento sobre o processo participativo realizado no estudo de caso desta pesquisa.

\subsubsection{O movimento popular}

O movimento social é um guarda-chuva de termos que foram sendo agregados ao longo do tempo, abarcando movimentos sociais urbanos, movimentos urbanos, movimentos de reivindicação urbana, lutas urbanas; depois, movimentos sociais populares, movimentos populares urbanos e movimentos urbanos. Teve sua origem por volta de 1840, para designar o movimento operário europeu (SCHERER-WARRER, 1987, apud DOIMO, 1995), depois desenvolvido no âmbito do marxismo, para representar a organização racional da classe trabalhadora em sindicatos e partidos políticos empenhados na transformação das relações capitalistas de produção. Mesmo antes da crise do socialismo e da queda do muro de Berlim, adquiriu a capacidade de referir-se a uma multiplicidade de novas formas de participação, sempre incorporando em sua filosofia a alteração da lógica capitalista, só que dessa vez com organização espontânea na esfera da cultura, enquanto novos movimentos sociais (DOIMO, 1995).

Desse modo, poder-se-ia dizer que o movimento social se divide fundamentalmente em dois tempos e seus significados. O primeiro, antes do socialismo, e sua origem operária concentrando toda a atenção na esfera econômica e na confiança na racionalidade do Estado. E depois do socialismo, final da década de 70, com postura de desconfiança e hostilidade em relação ao Estado, conformando um perfil heterogêneo de valorização da diversidade cultural e do pluralismo político em nome da democracia.

Não discutiremos aqui as polêmicas que têm gerado no campo teórico suas transmutações de significados, mas sim no campo de ação, seu rebatimento na prática, se houve mudanças, e em que termos. O seu entendimento ajuda a incluir os movimentos como 
processos participativos, originados fora das esferas produtivas e dos canais convencionais de mediação política, em espaços fortemente marcados por carências referidas ao vertiginoso crescimento e crise do estado capitalista (TEIXEIRA, 2000).

Passam então, a ter a compreensão do processo de participação popular a partir do entendimento do caráter educativo contido nesses movimentos, atrelado ao processo de cidadania coletiva implícito em seu interior. Conclui-se, a partir daí, que a educação não formal, a participação popular e a cidadania plena estariam indissociadas, tanto na prática quanto na teoria.

Dessa forma, o caráter educativo da participação popular se desenvolve fora dos canais institucionais escolares, tendo-se como pressuposto básico uma concepção de educação que ultrapassa os limites do aprendizado de conteúdos específicos transmitidos através de técnicas e instrumentos do processo comum pedagógico (GOHN 2001). O caráter educativo dos movimentos é auto-construído, surgido de diferentes fontes, a exemplo da aprendizagem gerada com a experiência no contato com fontes de exercício do poder; ou ainda da aprendizagem pela repetição de ações rotineiras impostas pela burocracia; da aprendizagem das diferenças existentes na realidade social a partir da percepção das distinções no tratamento que os diferentes grupos sociais recebem de suas demandas, e da desmistificação da autoridade como sinônimo de competência. A construção desse saber popular politizado e condensado em práticas políticas participativas constitui uma ameaça às classes dominantes. Por essa razão, observa-se uma tentativa freqüente, até os dias atuais, em delimitar esse poder apenas ao aspecto consultivo, sem colocar em risco a estrutura desse poder (BONDUKI, 1994).

A “educação popular” pelas práticas participativas abre lugar para a elaboração coletiva e crítica da vida individual e social das classes populares, uma fase de emergência dos novos movimentos sociais que se organizam como espaços reivindicativos, que recusam relações subordinadas de tutela ou de cooptação por parte do Estado, dos partidos ou das instituições; uma cultura participativa e autônoma, que se multiplica por todo o país e constitui uma vasta teia de organizações populares que se mobilizam em torno da conquista, da garantia e da ampliação de direitos. Nos anos 80, inicia-se uma articulação com federações municipais, estaduais e nacionais a exemplo da CUT — Central Única dos Trabalhadores e do Partido dos Trabalhadores.

Nesse movimento, a conquista de ter direito a ter direito a participar da redefinição dos direitos e da gestão da sociedade culminou com o reconhecimento, na Constituição de 1988, 
em seu artigo $1^{\circ}$, “de que todo poder emana do Povo, que o exerce indiretamente, através de seus representantes eleitos diretamente, nos termos desta Constituição.” Essa Constituição cidadã prevê a participação direta dos cidadãos pelos chamados institutos de democracia direta ou semi-direta, como o plebiscito, o referendo, a iniciativa popular de lei, as tribunas populares, os conselhos e outros canais institucionais de participação popular.

O processo constituinte sugere uma idéia de "participação” na construção de espaços de co-gestão; na luta pela reforma urbana, destacando a função social da propriedade e da cidade, prevendo o planejamento e a gestão participativa das políticas urbanas. Entretanto, até os dias atuais o processo constituinte não conseguiu consolidar um sistema articulado de conselhos, além do Estatuto da Criança e do Adolescente, da Lei Orgânica de Assistência Social, do Orçamento Participativo, como processos de consulta e debates sobre o orçamento público.

Por outro lado, ao longo desses anos, os movimentos populares não foram capazes de desenvolver projetos políticos, independentes e autônomos, pois se deixaram permanecer na dependência do apoio de assessorias. Essa foi uma grande limitação que não tem conseguido superar principalmente as crises econômicas do país, juntamente com o desemprego, aliada a uma forte descrença na política e na ação do Estado.

Apesar das diferentes formas de se construir tal desenvolvimento, que por se constituir numa interação permanente retro-alimentada tem seu entendimento em categorias e variáveis sem grau de prioridade. Essas categorias podem ser exemplificadas segundo uma organização política, ou seja, uma organização do grupo com a ajuda da assessoria de técnicos, políticos e religiosos. Desses grupos advêm as informações-chave para o êxito em determinado objetivo, em uma possível articulação e conseqüente concatenação entre o saber popular e o conhecimento científico/técnico, segundo uma cultura política fundada na participação que requeira a construção de canais onde haja a liberdade de expressão, pluralismo, a exemplo dos conselhos, do orçamento participativo, entre outros. E segundo, uma categoria de espaço e

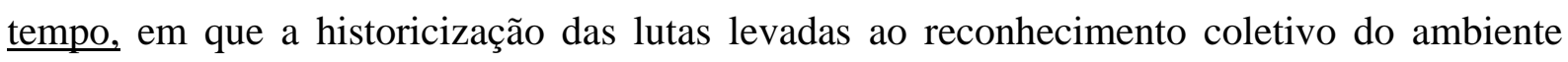
construído, do espaço gerado, seja apropriada pelas classes sociais na luta cotidiana, épocas em que se realizam festas populares e encontros religiosos, além de comemoração de alguma conquista, portanto, é o espaço, o local de comemoração comunitário, em que as representações fortes no imaginário popular acontecem (JEUDY, 1990; GOHN, 2001).

Para GOHN (2001), as principais formas de organização popular foram as associações de moradores, em que as demandas estavam atreladas às necessidades no setor urbano. Os três 
exemplos que podemos citar são as Sociedades Amigos dos Bairros - SABs ou associações de moradores, presentes desde as primeiras décadas do século XX. Portanto, as mais antigas. As outras formas seriam as associações de favelas e os movimentos específicos pela moradia ou equipamentos urbanos que, apesar de ter sua luta em torno de objetivos similares, diferiam na sua origem, processo de desenvolvimento histórico, articulações e relações sociais internas e externas. Essas diferenças se constatavam na prática do encaminhamento das demandas; dos projetos político-ideológicos e, no final, quanto ao rebatimento de suas demandas no espaço urbano construído.

As SABs têm seu auge em meados dos anos 40, no cenário populista, participando do jogo de barganha existente. Antes, período de 30 a 64, eram reivindicativas, de 64 a 74, assistencialistas e, ao mesmo tempo, de resistência. Com isso, muitos programas de lazer e assistência social foram implementados graças às SABs. Interessante é que nos quadros de diretoria das SABs a presença de militares era uma constante.

No período de 1974 a 1982, as SABs resgatam seu papel político em nível local, voltando a servir como canal popular. Na fase 1982, assumem seu papel político entre parlamentares e administradores públicos, inclusive colocando seu pessoal em órgãos políticos, facilitando o acesso à informação e ao processo interativo. Tiveram sua institucionalização oficializada e, por sua vez, aglutinaram-se em Conselhos e Federações Regionais, em que formularam estatutos e regimentos internos, dentre eles pode-se citar o CONAM - Conselho Nacional de Moradores.

Na análise de GOHN, um dos pontos questionáveis sobre as SABs seria que, como projeto político, elas não se preocuparam em mudar muita coisa, no sentido qualitativo, do processo de transformação social. Significativa até o presente momento foi a luta apenas para obter um bem demandado, especialmente o consumo de bens e equipamentos, ocasionando, para o momento, uma visão sem muitas surpresas em relação a projetos ou germes de mudanças sociais significativas. O segundo ponto é relativo ao fraco apelo à participação popular que, se antes levava ao fortalecimento dos laços de solidariedade, na atualidade, pela conjuntura econômica, esses laços se fragilizam, desenvolvendo outros interesses, entre eles o tráfigo de drogas. Finalmente, temo sua relação de discriminação com as favelas que, pelo seu estigma, levam a uma desvalorização dos imóveis adquiridos legalmente pelos moradores das SABs.

A contribuição das SABs na configuração do espaço urbano formou um dos principais instrumentos de planejamento e construção urbana das periferias, especialmente de São Paulo, 
reivindicando praças, ruas, demarcando lotes, além de terem participado como mão-de-obra na construção desses espaços. Enfim, a história do patrimônio ambiental está bastante atrelada à história das SABs, como demandatária ou executora desse mesmo planejamento.

Nas associações de favela, existem algumas diferentes modalidades. São elas: a dos moradores de rua, a dos alugadores e a dos conjuntos habitacionais precários. Elas tiveram sua presença destacada a partir da década de 70, embora a notícia que se tem das primeiras ocupações e invasões date dos anos 40, inicialmente, tendo os primeiros invasores, resistindo pacifica e persistentemente, depois recorrendo aos representantes políticos.

Nesse sentido, vale destacar o papel das CEBs - Comunidade Eclesiais de Base, da chamada ala da Teologia da Libertação. Através da Pastoral às Favelas, inúmeros agentes do clero passaram a residir nas favelas ou proximidades delas. Essa luta também estaria atrelada a um plano global contra o autoritarismo e o regime militar. É dessa época a iniciativa do governo em re-urbanizar as favelas, primeiramente simplificada através de fornecimento de água e luz, mas, na verdade, a lógica era outra, a de fazer pagar os custos de fornecimento e de implantação dos serviços prestados.

O próximo passo seria o da reconstrução das casas com material de qualidade, o qual se deparou com o embate de precisar do certificado de propriedade do imóvel para tomar empréstimo e a falta de título do terreno. Destaca-se nesse momento a dissociação entre posse do solo e propriedade resultante da "enfiteuse”, um instrumento jurídico de largo uso em Salvador, herança das capitanias hereditárias, direitos reais na coisa alheia ${ }^{8}$ E, com a enfiteuse de domínio direto ou pleno e de domínio útil (NEVES, 1985), que terminou dividindo o movimento (GOHN, 20021).

A terceira forma de organização seriam as associações e movimentos comunitários que ocorreram na mesma época das associações de favelas. Entretanto, aqueles eram impulsionados principalmente na primeira fase pelas práticas da Igreja Católica. A partir de 1980, a Igreja deixa de ser o único centro agregador das demandas populares na periferia. Em relação às SABs, diferenciava-se pela participação direta das bases, em que o importante era

\footnotetext{
${ }^{8}$ As terras eram propriedade do povo e só poderiam ser apropriadas legalmente, pagando uma espécie de aluguel ao governo, mediante proposta de uso, habitação ou como no caso da família Martins Catharino em que arrendaram grandes glebas de terra no subúrbio ferroviário para cultura agro-pecuária. Após a privatização das terras, já no século XX, a família que nunca havia utilizado as terras para tais propósitos, passou a ser proprietária dessas mesmas terras, em um processo pouco claro e dese então cobram o aluguel das terras para os moradores que a utilizam. A partir dos anos sessentas, tais moradores, que construíram suas habitações com recursos próprios nessas terras, se recusam a pagar tal aluguel. Existe um processo de legalização em andamentoaté os dias de hoje.
} 
sempre falar pelo grupo antes de consultá-lo. Todavia, existe uma dependência dos movimentos em relação ao apoio da Igreja, das estruturas físicas e dependência da própria condução da luta, que fica por conta dos agentes. Contudo, ainda se ganham dois aspectos importantes: o primeiro, de ordem física quantitativa, que seria a construção de conjuntos de casas por mutirão, e a segunda, de ordem social, que geram a organização da população, desenvolvendo uma consciência coletiva de acreditar em si, negando o exemplo clientelista de troca de favores.

Se até o final dos anos 80, os movimentos se mostravam como detentores de grande força política, denunciando a não prioridade da gestão pública para os setores sociais carentes, formulando demandas e até apresentando soluções e resistindo às pressões para se desmobilizarem, isso acaba após o processo constituinte, dando lugar a uma participação simplificada, calcada apenas na escuta de discussões sobre leis e, em outros aspectos, a consulta a projetos já sacramentados, sem grandes explicações detalhadas e possibilidade de mudanças (BONDUKI, 1994).

No quadro atual é comum ouvir que os movimentos sociais estão apáticos e, dos frutos que os movimentos dos anos 80 deixaram, o principal enfoque foi o de que qualquer categoria de indivíduo teria o direito de participar das questões que lhe dizem respeito. Esse fruto continua a existir, a se multiplicar, a exemplo dos movimentos ecológicos.

Tiveram um curto período de atuação as Câmaras Setoriais, espaços tripartidos de negociação de políticas industriais e de desenvolvimento — Governos Sarney e Itamar —, que, em virtude da crise automobilística, encontram facilidade para ser oficializadas. Ainda houve a Câmara Setorial da Construção Civil, envolvendo movimentos sociais e ONG's pela moradia popular que, infelizmente, teve curto período de atuação.

\subsubsection{O papel de cada um e a dificuldade em participar}

Ainda no final dos anos 70 e início dos anos 80, a participação de candidatos da esquerda vinculada aos interesses populares marca fortemente a trajetória de construção participativa no Brasil. Nos mandatos municipais em Fortaleza, Diadema, principalmente em São Paulo, com a prefeita Luiza Erundina, e Campinas tais candidatos partiram da proposta dos Conselhos Populares como espaços igualitários, paralelos ao poder do Estado.

A partir dos anos 90, os movimentos sociais e a complexa construção de possibilidades de participar passam por uma fase que enfatiza a necessidade de capacitação 
técnica e política das lideranças, possibilitando sua construção de maneira mais "qualificada” nos espaços conquistados. Surgem como destaque as ONG's, além de universidades ${ }^{9}$, centros de pesquisas, entidades profissionais, bem como militantes e profissionais que atuam individualmente.

As exigências, a eficácia e a valorização dos espaços de gestão participativa podem ser vistas também pelos novos desafios das lutas sociais. Enquanto no passado o importante era colocar para frente, nessa fase, a estruturação de táticas é fundamental para se construírem alternativas e se acertar o alvo, concretizado em habilidades e políticas viáveis.

Como resultado, a relação Estado/sociedade se torna mais permeável, possibilitando a apropriação e generalização, por parte do Estado e dos partidos do poder, de propostas para a negociação participativa e de controle social, diferentes do que havia sido proposto anteriormente pela sociedade. Nessa generalização, a abertura de canais institucionais, principalmente os conselhos vinculados ao repasse de verbas federais aos municípios, tornouse muito maior do que a demanda e o preparo da sociedade, encontrando uma sociedade civil frágil, com pouca capacitação técnica e política para proposições e acordos em políticas públicas. Formaram-se canais burocratizados, esvaziados de conteúdos democráticos, bastante segmentados, pelo despreparo e falta de vontade e de cultura política dos governantes do Estado.

Atualmente, o pleito participativo na política neoliberal tem sido implementada no sentido de desobrigar-se o governo de encargos sociais, principalmente os que não privilegiam o fortalecimento da cidadania, retornando aos favores e à caridade. Nesse processo está a privatização, a utilização dos conselhos ratificando políticas municipais supostamente progressistas, e possibilitando repasses de recursos submetidos ou supostamente submetidos a um controle social, quando não é escancarado, no caso do Conselho de Saúde de Salvador.

O sentido de cidadania fica claramente entendido como a inclusão das pessoas ao conjunto dos “consumidores” ${ }^{10}$, esvaziando-se o significado instituído, que garante e amplia continuamente o escopo de direito de participar, da definição e co-gestão de novos direitos. Esse é o significado neoliberal de cidadania, democratização, descentralização, participação e parceria conferida a inúmeros projetos governamentais sociais. Portanto, as mudanças propostas por nossos governantes ainda não passam de discursos acordados para permanecer

\footnotetext{
${ }^{9}$ Nabil Bonduque Lab-Habitat FAUUSP

${ }^{10}$ Somer, Robert, Design Social
} 
com o status quo vigente e sublimar o fluxo de poder com os governos internacionais e sua distribuição de lucro sem precedente, a exemplo de como vêm sendo utilizados os empréstimos do Banco Mundial e do FMI para “erradicar” a pobreza que eles mesmos vêm aumentando (WASHINGTON, 2001).

Nessa disseminação distorcida neoliberal, há de se destacar as que se dão pelos canais não institucionalizados, o MST, a Pastoral da Criança, os fóruns de iniciativa civil, produzindo ações que têm provocado mudanças nas agendas públicas. Independente da forma como vêm conquistando esses espaços, ressalta-se o MST, pois amplia sua forma de atuação na política, levantando questões e problemas coletivos públicos, a exemplo da tolerância, o respeito ao diferente, a divisão do trabalho doméstico entre homem e mulher, o cuidado com doentes mentais, crianças, jovens e anciões, todos sujeitos a ações participativas.

Outros movimentos ainda se destacam nesse processo, a exemplo da formação de assessorias técnicas em São Paulo, o que ocorre a partir dos anos 80. Esse quadro foi possível pelo desenvolvimento e implantação da autogestão. No início das discussões sobre autogestão para produção da moradia, os arquitetos observaram o exemplo que vinha acontecendo no Uruguai - experiência de 30 anos. Entretanto, essa questão ficou latente até o ano de 89, quando da administração da prefeita Luiza Erundina. Se por um lado essas assessorias contribuíram para a implementação dos projetos numa complexa interação com a comunidade num processo de aprendizagem mútuo, cujos conflitos são inerentes à trajetória democrática, por outro, a gestão Erundina possibilitou uma contribuição para a conquista da cidadania que ultrapassa a questão de um lugar para morar.

\subsection{Design com a comunidade}

Design é definido como sendo qualquer atividade com o propósito de dirigir um produto criado ou um processo que muda um ambiente ou uma organização. (REICH, 1996; SANOFF, 2006). Então, a participação é imprescindível como a primeira coisa a fazer de direito para todas as pessoas potencialmente atingidas pelo design, desde que esse se origine da necessidade, ao invés de simplesmente criá-la. Então, essa participação precisa ser legitimada, independente da origem da própria necessidade.

Uma das críticas que se faz ao design tradicional é que o envolvimento ativo do usuário vem depois do processo pronto do design. Sob esse ponto de vista, os usuários da mercadoria passam a ser essencialmente consumidores de produtos e, portanto, têm pouco ou 
nenhum papel direto na criação dos artefatos, ou mesmo o direito de comunicar suas próprias necessidades. A realização do produto é então utilizada e/ou pensada no sentido de tornar explícita uma carência não articulada com os usuários. Esse é o quadro perfeito da sociedade industrializada, em que a mercadoria é criada sem nenhuma articulação com a escassez do praticante e, portanto, torna-o um simples usuário e/ou consumidor (REICH, 1996).

Conhecido também como design participativo, sua discussão inicia-se nos anos 60, e significa envolver a população diretamente atingida pelas mudanças, antes mesmo da concepção do projeto e/ou design como produto final.

Uma das propostas apresentava o envolvimento dos usuários no processo do design, inicialmente pelos próprios designers, quando esses passavam a se colocar no lugar do usuário (REICH, 1996). Assim era possível uma compreensão mais próxima da necessidade do usuário, ele não precisaria se comunicar com os designers, por serem esses também usuários. Há de se considerar, entretanto, nessa perspectiva, que esses profissionais não padecem dos preconceitos e da falta de visão dos usuários em relação a seus próprios interesses. Daí a necessidade de contínuo processo de permuta de conhecimentos, em que a comunicação assume o papel fundamental de perspectiva conceitual e de troca de informação, sempre requerendo, dos designers e usuários que estão aprendendo, interpretação e tradução, construindo e envolvendo significados compartilhados da situação do design.

Esses profissionais precisam entender acerca das necessidades dos usuários, o contexto no qual o problema repousa e o que deve ser uma solução que convirá à personalidade e necessidades do usuário; enquanto os usuários, precisam aprender o que é possível alcançar, desse modo potencialmente modificando suas necessidades, como percebido e/ou compreendido inicialmente. Nessa situação ideal, cada participante delineia, segue, influencia, e é influenciado pela evolução de visões de todos.

A visão do design em que há o envolvimento ativo do usuário, ainda é pouco utilizada e, em muitos casos, esse envolvimento é evitado. Em outras circunstâncias, é apenas apresentado o projeto/produto pronto, sem que o cliente receptor tenha o poder de mudar alguma coisa. De acordo com essa visão, é de responsabilidade do profissional saber o que melhor trazer para o design. Mesmo quando a participação é uma demanda política, como é o caso do design de habitação pública, freqüentemente tem sido admitido como ineficaz, pelo antagonismo entre grupos de diferentes interesses, invalidando uns aos outros (REICH, 1996). 
Essa concepção de conhecimento do design resultando de uma participação exige mudanças em algumas divisões tradicionais de responsabilidade do design entre o especialista — o profissional —, e o usuário, mantendo-se apenas para chamar à atenção a diferença dos participantes, e deve ter sua legitimação no processo do design.

Assim, uma efetiva participação exige um contínuo compromisso. Duas posições são fundamentais e precisam ser encaminhadas constantemente. A primeira é o conteúdo da participação que se refere a todo tema discutido, e como todos os participantes vêm aprendendo as mudanças. A segunda é a forma de envolver, que precisa ser determinada na base do conteúdo das mudanças nas atividades do design e nas experiências acumuladas em projetos participativos. Embora a forma deva ser guiada, precisa estar pronta participativamente. De outra maneira, as diferenças entre as forças serão mantidas, impedindo assim uma cooperação mais efetiva para o trabalho.

Os cidadãos podem melhorar suas decisões políticas e sociais quando são considerados os princípios de autonomia cidadã e automelhora. Dentro desses princípios, os métodos participativos exigem que ambas as autoridades, local e governo central levem seriamente em conta a opinião pública. Os métodos participativos têm também a intenção de apoiar o cidadão na tomada de decisão, especialmente sobre o planejamento e design para a construção do ambiente.

Isso exige um cuidado especial na comunicação entre os participantes, para poder promover condições favoráveis para a participação cidadã na construção do ambiente. Somente através da introdução de técnicas de participação, ambos, público e profissionais, podem compreender a oportunidade para uma parceria. Essa parceria precisa ter flexibilidade no momento de aplicação dos métodos no desenvolvimento dos sistemas de planos, em razão da variedade de problemas que aparecem em diferentes camadas da sociedade. Esse argumento pode também ser aplicado às diferenças locais, tal como a maneira pela qual as pessoas se organizam para terem sua visão e construírem seu conhecimento, ou como reagem às propostas apresentadas a elas.

Não deixa de ser político tocar em aspectos da vida social que, de alguma forma, mudarão a maneira como elas vivem no presente. Portanto, depende da estrutura política o que pode ou não facilitar a participação, ou mesmo apenas promover a pseudoparticipação, significando que o governo central e local não permitirá ao público compartilhar de nenhuma forma da tomada de decisão, pelo simples motivo de que não há interesse da consciência política em determinado fenômeno, de conceber a participação popular. 
Possivelmente a participação caminhará no sentido de identificação comum diante das diferenças de opiniões e conflitos de interesses. Em tal situação, o consenso, inicialmente, é o inimigo da participação. Então, se o designer ou planejador deseja incorporar em seus projetos as necessidades dos usuários, possivelmente tais profissionais precisem estar conscientes dos políticos, das tomadas políticas e sua implementação no governo local.

Os técnicos que pretendem efetivar a participação precisam assegurar às pessoas uma posição madura, baseada em informações claras e precisas na compreensão comum, para realizar as decisões mais eficientes.

Os governos usualmente emperram em seus propósitos, sejam quais forem os fatos e argumentos apresentados contra eles. Entretanto, para a aplicação de uma técnica total de participação, a decisão final deve vir do cidadão.

Muitas limitações ocorrem, em especial a que o Estado argumenta de que os planos e desenhos precisam permanecer na mão do governo local ou das autoridades do planejamento e do design. Todavia, o público tem de entender esse processo e ser envolvido na tomada de decisão e comissão para o programa. Isso sugere uma influência das ações do planejamento atual ou público sobre um método apropriado de políticas participativas, o qual deve capacitar as pessoas para alcançar uma efetiva e eficiente participação no design e construção do ambiente.

\subsubsection{Community Design}

HATCH (1984), em In the Scope of Social Architecture, descreve um movimento internacional fundamentado na convicção plena de que a participação é crucial para a redireção da formação de cidades, sendo a arquitetura social o instrumento capaz de transformar o ambiente e as pessoas que vivem nele. Isso restabelece o sentido de lugar e encontro, interrompendo a alienação da sociedade em relação às mudanças, impregnada pelo movimento moderno.

Community design ou arquitetura social é uma atitude que enfoca mudanças na criação e gestão de ambientes para pessoas, contrária às tradicionais fronteiras de profissionais especialistas. A atividade do Community Design está baseada no princípio de que o ambiente é melhor trabalhado se as pessoas atingidas por essas mudanças são ativamente implicadas em sua criação, desenvolvimento e gerenciamento, em lugar de serem tratadas como passivos consumidores (SANOFF, 2000; WATES, 2000). 
Community Design, entretanto, não é nenhuma panacéia ou solução para as mudanças sociais. Necessita de estudo e muita discussão sobre a teoria e a prática, para então se tornar um aspecto integral da democracia. Na distorção de seu significado, a participação, tal como entendem SANOFF, TEIXEIRA, DEMO e outros autores, precisa de um propósito claro de acordo com cada projeto, mesmo antes da tomada de decisão de se iniciar qualquer processo.

Um dos eventos marcantes sobre o tema aconteceu na Conferência de Manchester, em 1971 na Escola de Arquitetura da Universidade Aarhus, Inglaterra, intitulado: Design Participation, na qual os profissionais expressaram sua visão sobre a participação dos usuários no processo da atividade do design. Essas diferenças chamaram a atenção da Foundation for Architect Research, no final dos anos 60, e introduziram um conceito de participação do design, tanto para habitação como para os espaços coletivos ou até mesmo como um produto para o consumo.

Por isso é importante fazer uma distinção entre decisão que pode ser feita por um grande grupo de usuários e o que pode ser feito apenas pelo usuário individual. Essa distinção foi apresentada por HABRAKEN (1972), e conhecida como "apoio" ou infill, o detalhamento de sua proposta ajuda a entender melhor tal diferencial.

O conceito original de support and infill foi formulado por JOHN HABRAKEN, no seu livro Support, An Alternative to Mass Housing. Nesse livro, ele faz um diagnóstico crítico dos processos convencionais de produção da habitação, especialmente porque o usuário não foi envolvido, supondo que o profissional faça a decisão certa. E ainda sugere que, para remediar a situação e restaurar a responsabilidade do usuário, a forma seria o controle desse usuário na sua unidade individual. Esta iniciativa por um lado se justificava pelo fato de o processo industrial não estar interessado na produção de habitação do sistema convencional e, por outro, o usuário não estava satisfeito com o aspecto generalizado de sua moradia.

HABRAKEN desenvolveu um número de elementos que chamou de infill ou “enchimentos”, produzidos em série, que dariam apoio à individualização espacial de cada moradia. Além disso, também desenvolveu o processo no qual técnicos e usuários trabalhassem juntos. O design, a produção e a distribuição desses elementos de “enchimentos” deveriam seguir o padrão de durabilidade de objetos do próprio consumidor. Com tais idéias, surgiu um grupo de arquitetos que se juntaram e, com a Dutch Union of Architects, fundaram a SAR - Foundation for Architects' Research. Esse grupo estava entusiasmado com a perspectiva de melhorar a qualidade da produção habitacional em série com o envolvimento 
dos usuários. HABRAKEN foi convidado pela $S A R$ a ser o coordenador do projeto que desenvolveria em maiores detalhes tanto o processo como o projeto.

No final do ano de 1965, o método $S A R 65$ foi publicado, apoiando arquitetos com ferramentas do design. O escritório do $S A R$ fez um enorme esforço para incrementar o support-infill e acompanhar o método. Entretanto, a transferência de tecnologias por parte dos arquitetos tomou diferentes rumos na prática, por diferentes dificuldades que tiveram de ser resolvidas de acordo também com os limites locais, e isso não havia sido previsto no manual. Mesmo assim, a SAR montou uma comissão para investigar cuidadosamente a razão por que e como estavam ocorrendo as distorções. O estudo chamou-se Boundaries between support and infill, e tinha como objetivo tornar transparente o caminho dos diferentes objetivos que poderiam influenciar a identificar o limite dessas mudanças. Mais tarde, como reforço ao estudo, uma comissão do Ministério de Habitação iniciou alguns estudos, tentando localizar os empecilhos que precisavam ser removidos, para que o projeto fosse efetivo.

Os dois estudos mostraram que os desafios surgiam como resultado de numerosos objetivos que poderiam ser perseguidos, e iam-se revelando, dependendo das misturas de objetivos escolhidos, como também das prioridades. Resumindo: os desafios apareciam de acordo com a complexidade e especificidade de cada situação, como resposta do contexto existente, com todas as suas características e diversidade própria.

\subsubsection{Reconhecimento do termo e desenvolvimento da teoria}

No início dos anos 1960, o papel do usuário começa a ser discutido nos círculos profissionais. As experiências de TURNER no Peru e a de HABRAKEN na Holanda são publicadas. A partir desse momento, alguns discursos e muitos escritos apresentam a preocupação em relação ao papel do usuário no processo do design. Em meados dos anos 1960, o termo participação aparece com uma conotação política intensiva.

Para COMÉRIO (1990), existiram duas fases, a idealista, entre final dos anos 60 e meados de 70, e a empreendedora, nos meados e final dos anos 70. Cada uma dessas fases pode ser caracterizada pelo tipo de projeto de que foi encarregada, o tipo de cliente a ser atendido, os objetivos que eram esperados e os resultados reais que eram alcançados.

O termo passa a ser apresentado sob um número de sinônimos, como envolvimento cidadão, influência cidadã, grupo de ação cidadã, cooperação, co-decisão, autodecisão, entre outros. Isso implica uma generalização de conceitos, perpassando por diferentes formas 
de tomada de decisão por um número de partes envolvidas. Nesse sentido, muitos autores têm cuidado, e outros preferem não usar o termo com freqüência. Algumas palavras foram surgindo para aclarar o papel do profissional e do usuário. Ter voz e/ou ter o poder de decidir é a questão crucial que define a relação entre mundo profissional e o mundo das pessoas leigas e aonde se quer chegar.

Na literatura internacional, o termo mais comumente divulgado foi apresentado como Design Comunitário (SANOFF, 2000; WATES, 2005). É conhecido também sob outras expressões tais como Planejamento Comunitário; Arquitetura Comunitária; Arquitetura Social; Desenvolvimento Comunitário e Participação Comunitária. Como movimento, constitui-se em um dos caminhos para corrigir a má administração do ambiente físico que vinha causando muitos desajustes sociais e econômicos. Era uma crítica severa ao movimento moderno, tanto na América do Norte como em outras partes do mundo, responsável pelo caos e destruição do espírito comunitário nas cidades. A maior parte dos defensores desse ponto de vista foram os profissionais da área de arquitetura, arquitetura da paisagem, e planejadores urbanos.

Oficialmente, foi reconhecido nos anos 80, quando a Organização das Nações Unidas definiu o termo community development, considerando que a participação de comunidades locais seria uma das principais estratégias do desenvolvimento sustentável, destacando que a participação das comunidades era condição necessária para a ampliação de oportunidades a fim de que todas as pessoas fossem envolvidas politicamente e partilhassem da expansão do processo. Portanto, o conceito de participação não foi somente um processo técnico ou ferramenta daquele período, mas na atualidade passou a existir como um mecanismo social refletindo a transição da natureza política em direção ao sistema democrático.

O significado na participação tem sido comumente associado à idéia de envolver a população local no desenvolvimento social. A influência, segundo SANOFF (2000), veio dos países emergentes e seus movimentos sociais nos anos 50 e 60. A premência de uma teoria de participação comunitária surgiu como uma abordagem do progresso social. Nos países do Norte, a democracia popular esteve ligada às lutas de base comunitária dos anos 60, no contexto do movimento de lutas pelos direitos civis, liberação das mulheres, antiguerra e o desafio das culturas alternativas, no qual todos representaram sinal de uma grande mudança no quadro da sociedade civil.

Um dos modelos de constituição comunitária foi proposto por ALINSKY (1968). Entre as atividades, havia a organização de protestos urbanos para melhoria nas condições de 
vida dos "pobres", e o fortalecimento da classe popular para obter mais democracia e melhor justiça social. ALINSKY também acreditava no pluralismo, na descentralização e na autonomia local. Entretanto, o que aconteceu foi o sistema ter criado uma intensidade de instituições locais, em que as pessoas ficaram excluídas do processo devido à burocratização exacerbada, mantendo-se, assim, a centralização e, especialmente, o controle e a manipulação de informações. Deflagrou uma enorme fragilidade, primeiramente por interromper a iniciativa espontânea dos movimentos, e a seguir por impor uma mobilização em torno de interesses baseados em idéias da instituição, ao invés do interesse imediato da própria população.

ALINSKY tornou-se especialista em construir comunidades organizadas, mobilizando-as em torno de uma questão que defendesse rapidamente o interesse delas, identificando inclusive as barreiras e os desafios para solucionar tal questão. Uma vez que os esforços fossem bem sucedidos e o poder da comunidade reconhecido, as instituições democráticas iniciariam um trabalho a seu favor e, conseqüentemente, tornariam os interesses econômicos equilibrados.

Em sua experiência, ALINSKY deixava que a própria comunidade elegesse sua liderança, para então retirar-se, após consolidada e amadurecida sua estrutura organizacional, inclusive identificadas suas lideranças. Na estratégia de ALINSKY, o organizador, como facilitador e educador, jamais deveria tomar parte do movimento, mas interferir apenas em assuntos essenciais o suficiente para informar e orientar a comunidade. A maior parte de suas experiências começou por iniciativa de uma única instituição: a Igreja.

Os métodos de ALINSKY procuravam tornar realidade uma democracia participativa, que selecionava os bairros menores para estimular o domínio local contra a centralização. De acordo com as pesquisas de seus trabalhos em constituição comunitária, ALINSKY concluiu que a organização comunitária ainda não estava preparada para reverter a tendência em direção à desintegração do grupo tão logo fossem atendidas as demandas. As experiências mais positivas que ocorreram na década de 70 demonstraram que, com a crise econômica, a classe média, atingida pela rápida decadência em sua qualidade de vida urbana, organizou-se em um grupo multicultural, fundamentado em um amplo leque de questões em políticas econômicas, contra o aumento de taxas e imposto destinados para o armamento, o que desviava verbas do sistema de saúde, conseqüentemente, levando a uma baixa qualidade na seguridade social. 
Nesse cenário, surge também o planejador e advogado DAVIDOFF, desafiando outros planejadores a promoverem uma democracia participativa e mudança social mais positiva, superando a pobreza e o racismo e reduzindo as disparidades entre os ricos e os pobres. Desafiou os planejadores a se tornarem defensores daquilo que eles julgavam mais apropriado, pois ele entendia a defesa como um caminho de capacitação para o grupo como um todo na sociedade, particularmente as organizações representando aqueles que não tinham voz, famílias de pouco recursos. Dizia que um planejador deveria procurar expandir escolhas e oportunidades para todas as pessoas, reconhecendo a responsabilidade social do planejamento para os grupos e pessoas em desvantagem.

Influenciados por essas idéias, muitos profissionais do design, do planejamento, aderiram ao modelo, rejeitando as práticas tradicionais do movimento moderno. Lutaram contra o redesenvolvimento urbano, defendendo os direitos dos cidadãos de poucos recursos, e aprimorando métodos em que o cidadão com mais efetividade tinha papel importante. Com essa proposta surgiram os Centros de Design para Comunidades - Community Design Centers - CDCs.

O momento social dos atos pelos direitos civis (1957) e as inovações do Programa das Áreas Degradadas apresentado pela Fundação Ford iniciado nos anos 60, rapidamente, teceu o fundamento para mudanças através da nação. A organização governamental entrou para estimular o processo criando o Escritório de Desenvolvimento de Bairros - Office of Neighborhood Development - dentro do Departamento de Habitação e Desenvolvimento Urbano.

A constituição de comunidades foi também reconhecida e incentivada pelo governo federal em países da América do Norte, América do Sul e Europa, através de programas e políticas federais, a exemplo da Microbrigada Social Chichi Padron ${ }^{11}$, Santa Clara, Cuba, e o Community Action Program nos Estados Unidos. Esses incentivos enfatizavam a participação do morador nas melhorias de programas, nos quais tradicionalmente os profissionais decidiam questões-chave, controlavam recursos e assumiam riscos. As comunidades constituídas passaram a ter um papel central e atuante tanto no planejamento como na implementação.

\footnotetext{
${ }^{11}$ Microbrigada Chichi Padron está estabelecida no Bairro Condado, em Santa Clara, a terceira maior cidade de Cuba, com aproximadamente 200 mil habitantes. O bairro Condado surgiu nos anos 50 a partir da migração de camponeses. A Microbrigada Chichi Padron foi fundada nofinal dos anos 80 por iniciativa do governo municipal e se tornou a principal organização do bairro, com a qual todos se identificam. Participa de um programa de intercâmbio entre as Faculdades de Arquitetura de Santa Clara e de Kassel, Alemanha.
} 
A constituição de uma comunidade é uma tarefa holística, promove muito mais uma aproximação entre pessoas do que qualquer outro aspecto, como a técnica e os custos. Está atrelada à idéia de que os moradores necessitam ter controle de seu destino e de sua comunidade, amadurecendo as normas e procedimentos ao exercitar um olhar cada vez mais detalhado de como a comunidade constrói e reconstrói o seu cotidiano, em que seus integrantes passam a criar instituições que ajudam e orientam o alcance de suas aspirações, bem como o esforço para tecer as redes comunitárias.

\section{3 A matriz discursiva sobre participação}

Participação como conceito geral perpassa formas diversificadas de tomar decisão sobre um número de grupos envolvidos. Se for dirigida com efetividade, a tarefa para participar será pensada em termos de quais objetivos alcançar e de quando a necessidade em envolver cidadãos é reconhecida. Conceituar a participação significa perguntar para quem, para quê, onde, por quê, como e quando.

Certamente, as que serão afetadas pelas mudanças e decisões do planejamento ou projeto deverão ser envolvidas no processo de tomada de decisões. Devem ser envolvidas se, por exemplo, a participação tem a intenção de generalizar idéias; identificar atitudes; disseminar informações; resolver alguns conflitos identificados; revisar propósitos, ou se simplesmente será para servir como satisfação de extravasar emoções. Quais são os objetivos, e por que as pessoas têm de ser envolvidas? Essas questões ajudam a identificar o método. Questões prioritárias são: em que momento os participantes devem ser envolvidos? Se no desenvolvimento, na implementação, na avaliação ou em algumas dessas combinações?

As diversificadas formas e estágios em participar são resultado de diferentes influências das partes arquiteto e usuário, tornando-se uma escala recíproca, diminuindo a influência do arquiteto, seguida pelo aumento da influência do usuário. O perfil da participação está muito em função do caráter do projeto e do período em que a participação deve ser requisitada no processo. Por exemplo, o período durante a fase do design, ou durante a fase da construção e a participação na manutenção depois de completado o projeto. O efeito da participação durante esses três períodos tem de ser o objeto de um estudo especial, supondo-se que esses diferentes níveis de fases terão influência considerável nas condições do design, tanto das edificações como dos espaços urbanos. 
A pré-condição para uma participação efetiva está nas decisões e nos produtos de arquitetura que trazem características da influência e modificação feita pelos usuários. Isso pressupõe que os participantes tenham um determinado nível de conhecimento e entendimento do assunto. Parte desse conhecimento existe já no início do processo e parte vai acontecendo no seu transcorrer e até depois que o processo participativo é deflagrado. Sendo a participação estabelecida como processo e não como uma ação, significa que tem que ser aberta, influenciável e modificável. Aberta porque conhecimentos são partilhados e outros novos são adquiridos; assim está implícito que a participação é um processo pedagógico (WULZ, 1986).

Há ainda que considerar que participação tem diferentes significados para diferentes pessoas, e mesmo diferentes significados para a mesma pessoa, de acordo com a situação também. Outras definições de participação ainda são encontradas na literatura. Esta participação pode ser contextual, logo varia em tipo e nível de intensidade, extensão e freqüência. Na revisão de literatura, SANOFF (2000) identifica dois níveis de participação.

I) Pseudo-participação, subdividida em:

• domesticação que envolve informação sobre a situação, ou a manipulação;

- $\quad$ assistencialismo.

II) Participação genuína:

- cooperação que se refere a uma co-participação e distribuição de força;

- $\quad$ controle do cidadão que vem a significar a capacitação do sujeito.

Para SILVA (1998), numa pesquisa realizada pelo LabHab ${ }^{12}$ — em que a participação fazia parte da retórica de todos os programas de governo - foi possível identificar três níveis de intensidade de participação, com semelhança nos propostos por SANOFF (2000):

I) participação informativa: a comunidade é informada do que virá a ser feito, sem ela ter o poder de interferir;

II) participação consultiva: a comunidade foi informada e ouvida, com possibilidade apenas de interferir caso o agente promotor resolvesse admitir essas mudanças;

\footnotetext{
12 “Parâmetros Técnicos de Urbanização de Favelas”, em que o objetivo era avaliar as características e qualidades técnicas de obras de urbanização de oito favelas, envolvendo cinco municípios brasileiros, no qual entrou, como fator preponderante, a participação da comunidade.
} 
III) participação interativa: a comunidade, por iniciativa própria ou do agente promotor, participou ou foi chamada a participar das decisões sobre o que iria ser feito.

Naquela pesquisa pôde-se concluir que as observações baseadas nas informações, quando comparadas aos resultados levantados em campo, indicava que a prioridade, de fato, era apenas um processo de informação à população sobre o que iria ser feito na comunidade, sem possibilidade de mudança pela mesma.

A participação das pessoas, em que o controle do projeto permanece na mão das instituições, é pseudo-participação (SANOFF, 2000). Fica claro que nesse nível de envolvimento os presentes apenas ouvem o que foi planejado para eles. O que definitivamente, no consenso dos autores pesquisados, não é uma participação genuína ou interativa. Uma participação genuína, para SANOFF (2000), ou participação interativa, para SILVA (1999), ocorre quando as pessoas têm força para controlar as ações que elas priorizam e desejam. Assim, as distinções entre as formas de participar são importantes, pois implicam cuidados em considerar o comportamento e a comunicação do futuro processo, e de como trazer o conhecimento e compartilhar a aprendizagem entre as partes envolvidas.

A participação não está livre de conflitos, mas pode, por outro lado, unificar visões contrárias, em que muitas das diferenças de opinião podem ser clarificadas antes de se tornarem mais inflamadas e causar conflitos destrutivos.

Não existe uma melhor solução para determinada questão, pois cada situação tem um número infinito de respostas. Por essa razão, a participação vem reforçar a escolha dessas soluções, porque estarão entendidas e fundamentadas na valoração da população beneficiada.

Nesse sentido, quanto mais efetivo o envolvimento da população, maior será a ampliação dos recursos empreendidos, e serão ampliados na medida que têm uma repercussão melhor na aplicação desses recursos, estando implícitos aspectos de satisfação dos moradores, seja na identificação de suas idéias no projeto, seja nas melhorias fundamentadas em sua própria realidade, seja no entendimento das novas condições do espaço produzido.

Envolver pessoas no processo do design para tomada de decisão e, como resultado, aumentar a confiança delas na organização tornam mais aceitáveis as decisões e planos, portanto, trabalham melhor nas soluções dos problemas, dentro do sistema estabelecido. Além disso, promove o senso de comunidade, ao reunir os que compartilham objetivos comuns. Por outro lado, para o grupo de usuários, representa um enorme ganho ter influenciado o processo 
de tomada de decisão e, conseqüentemente, há um aumento na consciência das conseqüências das decisões feitas.

Um dos pontos fundamentais no processo participativo indiscutivelmente se constitui no aumento do aprendizado do indivíduo na descoberta e conscientização de um dado problema. Para ampliação desse processo, a linguagem deverá ser clara, comunicável e aberta, inclusive encorajando o diálogo, o debate e a colaboração. Participar é um envolvimento público direto no processo de tomada de decisão, que determina a qualidade e a direção da vida da sociedade como um todo.

Se a participação tem a capacidade de apresentar a diversidade de expressão, por sua vez, a solução do design e planejamento precisam ser transparentes, para que as decisões sejam entendidas por aqueles que as fizeram, através de convocação pública de fóruns que encorajem a participação comunitária, em que as pessoas podem abertamente expressar suas opiniões, estabelecer seus compromissos, e chegar a decisões aceitáveis. Envolver ao máximo pode trazer riqueza ao início do processo, e também melhor conhecimento sobre a relação da comunidade com o lugar.

A participação no processo do design e do planejamento deve envolver questões tecnológicas. Para um bom resultado, especialistas em vários campos devem ser requisitados para cooperar. Fica evidente que as instituições públicas devem ser envolvidas no processo logo a decisão final não significa final de processo. O projeto e o processo ainda precisam ser gerenciados, avaliados e adaptados às mudanças que se fizerem necessárias.

\subsubsection{Os pressupostos para participar}

Os principais pontos a considerar na constituição comunitária passam pelo envolvimento dos residentes na definição do cenário; na priorização dos objetivos e na escolha das estratégias para alcançá-los. Durante o processo, é importante destacar os ganhos e o que a comunidade deixou de ganhar. O tamanho da comunidade definirá se o trabalho é gerenciável ou se terá muitas dificuldades para manter-se estável, coeso e consistente a maior parte do tempo. As estratégias serão específicas para cada bairro ou grupo. Enquanto está-se constituindo o capital social, os valores da comunidade deverão ser reforçados e trazidos com clareza às discussões entre os participantes.

Integra todo esse cenário de constituição de uma comunidade o desenvolvimento de parcerias criativas, com instituições existentes na cidade, considerando a aproximação do que 
vem de cima para baixo e de baixo para cima, entre os moradores, os administradores, e a comunidade organizada. Através da participação na definição do cenário, na priorização dos objetivos e na escolha das estratégias para alcançá-los, os moradores assumem o pertencimento no processo. Tais atores envolvidos na constituição comunitária investem seu tempo trabalhando conjuntamente em atividades producentes para solucionar as questões que eles identificaram, desenvolvendo as redes de solidariedade, credibilidade mútua, estreitando o que eles têm de valores comuns. É importante para o processo de construção de comunidades que o espaço dessas negociações seja no local do bairro onde moram essas pessoas, possibilitando o confronto e a interação face a face, desenvolvendo a habilidade de elas se conhecerem, estabelecendo uma confiança mútua.

Os moradores precisam desenvolver um olhar unificado do que querem para seu bairro e de como chegar lá. Para iniciar o processo, um sinal positivo deve ser trazido à discussão, sobre a história local, inventariando as vantagens daquela comunidade para, a seguir, encontrar caminhos e oportunidades para criar programas de ação e atividades que possam alcançar os objetivos estabelecidos. Os problemas mais complexos devem ser reconhecidos durante esse processo, mas não devem ser destacados com muita ênfase em detrimento dos positivos, pois a comunidade perderia a perspectiva de ter o poder de resolver seus problemas.

Para planejar um programa participativo, o primeiro passo é a identificação dos objetivos. Precisa-se de tempo para levantar e analisar questões, identificar participantes, recursos, e priorização de objetivos para a escolha do método participativo. Os princípios para ocorrer a participação fundamentam-se na afirmação de que para cada problema existe um número infinito de soluções: depende do valor de quem toma a decisão. Por outro lado, a deliberação do especialista não é necessariamente a melhor. Revelando os fatos, os usuários podem examinar as alternativas disponíveis e escolher alguma delas.

O especialista envolvido nesse método deve ser considerado um participante do qual se espera seja capaz de identificar as alternativas possíveis e apresentar para serem discutidas coletivamente as conseqüências das variáveis, emitindo uma opinião. As tarefas do arquiteto devem ser transparentes, considerando suas alternativas, trazendo uma compreensão coletiva, em que todos sejam capazes de emitir pensamentos e idéias. Após o entendimento de todos os componentes do planejamento e do design e a exploração das alternativas, os usuários devem gerar seu próprio plano, ao invés de reagir contra outro plano apresentado pelos especialistas.

Nesse percurso, os interesses individuais e os do grupo podem aparecer ao mesmo tempo em que as pessoas expressam suas opiniões e visões abertamente, comprometendo-se a 
apresentar soluções que sejam aceitas por todos que estejam preocupados em resolver a questão. O processo é contínuo e saudavelmente permutável; o produto não representa o final, ou seja, ainda precisa ser gerenciado, reavalidado, adaptado para as mudanças necessárias.

O próximo passo é a construção de consenso, que deve ter um alcance maior que o tradicionalmente conhecido. No primeiro momento, importa às pessoas muito mais o reconhecimento de um interesse comum do que partilhar objetivos. É imperativo entender o interesse de outros e não necessariamente estar de acordo com tais interesses. Entretanto, o termo tem um significado mais apropriado se entendedido como uma avaliação e reflexão coletivo, e não a decisão da maioria. Nesse sentido, o consenso não é uma ferramenta para tomar decisão, mas o alicerce no qual a cooperação é possível. Desse modo o processo precisa assegurar que cada preocupação apresentada individualmente seja ouvida e bem entendida, e que existe uma tentativa honesta de que seja incluída na busca de soluções. A situação ideal é a de que não haja limitação no processo de discussão; o indivíduo precisa sentir-se livre para expressar sua preocupação individual.

Nenhum dos participantes deve ter mais ou menos oportunidade de discutir seu próprio desejo ou necessidade, as hierarquias devem ser abolidas, e assim todos os participantes devem assumir igualdade de poder. Quando a competição se instala, indica que o interesse comum do grupo está enfraquecido.

O modelo ideal de organização de consenso deve pretender o estabelecimento de parcerias entre as lideranças do setor privado, do público e de grupos das comunidades, através de caminhos efetivos nos quais o indivíduo passasse a usar e desenvolver suas próprias habilidades e criatividade em nome de sua comunidade. Esse modelo precisa enfatizar estratégias, pragmatismo, e construção de relacionamentos.

A constituição do consenso em uma comunidade inicia-se com a identificação e o envolvimento de uma instituição local capaz de prover de recursos financeiros o processo, apoiando sua organização. A seguir, faz-se uma avaliação dos interesses da comunidade e da cidade. Uma avaliação para o envolvimento da cultura da comunidade inclui uma análise dos esforços e fraquezas dos grupos comunitários, assim como as ligações que já existiam entre o serviço social e as agências governamentais e bancos e fundações locais. A meta do processo é a construção da organização comunitária, acompanhada pelo envolvimento dos moradores e desenvolvimento de lideranças diversificadas, nos quais todos os segmentos da comunidade colocam sua representação. 
No processo participativo, a decisão colaborativa encoraja a criatividade, abre os canais de comunicação, amplia o envolvimento das pessoas e, conseqüentemente, reduz conflitos quanto à complexidade de problemas e diversidade de interesses. A constituição de consenso em colaborar para a tomada de decisões ocorre em vários estágios. Entretanto, para começar é necessário que todos os participantes compartilhem um propósito, trabalhando juntos para partilhar informações, assim um amplo acordo exige processo transparente e explícitas operações de procedimentos. Podemos orientar o alcance das conciliações nos perguntando por que esse processo é necessário, qual a maneira de resolução é exigida, como o grupo trabalhará para perseguir seus objetivos, como as decisões serão feitas, qual o calendário, quem receberá e colocará em prática o produto final.

A seguir, haverá as trocas de informações e a identificação de quais as novas informações a serem exigidas. Uma base comum de informações é imprescindível para solucionar efetivamente determinado problema. As discussões trarão o aclaramento do problema para todos os participantes, refletindo dessa maneira uma preocupação de todos, com gerenciamento dentro do prazo e dos recursos à disposição.

Para definição do problema existem alguns métodos, além da descrição verbal, os diagramas e gráficos, fluxogramas e os modelos para ajudar os participantes a entenderem melhor o problema físico. Problemas mais complexos devem ser subdivididos em partes menores e manuseáveis, distribuídos aos grupos para, a partir de então, serem encaminhados para o grupo completo. O consenso para a confirmação de um problema terá seu melhor alcance quando cada participante tiver se expressado com suas próprias palavras e vocabulário; o mesmo deverá acontecer para todos os elementos do problema.

Por ser um processo complexo, a participação para a tomada de decisão requer procedimentos consideráveis, seu grau de complexidade definirá qual o método a ser aplicado. Um desses métodos, a charrette, é utilizado para problemas de natureza multifacetados. Funciona para orientar os participantes a visualizar melhor as implicações em três dimensões, mais do que as contidas nos desenhos; largura e comprimento.

Outro método é a visualização de preferências, os inventários, e a avaliação, utilizados em uma boa definição de cenários, demonstrando características positivas ou negativas de uma situação existente ou proposta.

A etapa seguinte é a geração de idéias, sem julgamento, e discussões, antes de exaurir todas as opções, à semelhança do que conhecemos em inglês como brainstorming. Para 
chegar a uma solução mais apropriada é necessário estabelecer com os participantes um critério de avaliação das alternativas e, para isso, existem inúmeros métodos de avaliação.

\subsubsection{Fragilidades e desafios}

A participação tem sido requisitada com mais freqüência ultimamente. A combinação da legislação com as demandas dos cidadãos tem promovido uma participação cidadã essencial, que vem sendo exigida em qualquer projeto de urbanização. Para a maioria dessas experiências, a falta de clareza sobre o próprio termo se constitui como fonte principal de conflitos e confusão. Como conseqüência, o próprio processo participativo se constitui numa barreira para o envolvimento das pessoas.

Alguns profissionais afirmam que os participantes não têm conhecimento suficiente para discussão. A complexidade técnica das questões do planejamento e do desenho urbano e seus problemas podem desencorajar ou inibir a participação, especialmente sem a habilidade de um facilitador. Se as organizações de planejamento apropriam-se antecipadamente do envolvimento da comunidade, através de definições e problemas de maneira muito elaborada com vocabulário específico, promovendo para os não profissionais, dificuldades no entendimento de aspectos técnicos, certamente tais instituições engendram passividade, dependência e ignorância (FORESTER apud SANOFF, 2000; TURNER,1977).

Apesar das diferentes opiniões e preferências, ignorá-las pode levar a um resultado de insatisfação considerável. O mesmo acontece quando excluímos os usuários no processo de planejamento e design, assumindo que todas as pessoas são iguais e que o produto final é totalmente uniforme, no qual todo mundo tem desejos idênticos. As duas abordagens darão também, como resultado, descontentamento geral. TURNER (1977) nos dá o exemplo de Saint Louis no Missouri, em que um prédio foi todo demolido vinte anos depois, devido a seu estado precário por mau uso e vandalismo, tal edifício, conhecida como Pruitt-Igoe, ganhou o prêmio de arquitetura. Assim, a durabilidade dos espaços e das edificações está mais relacionada que com as instituições humanas que as tecnologias de construção (TURNER,1977).

A participação dos não técnicos pode ser ameaçadora para os profissionais e gerenciadores em seu papel de especialistas, pois se sentem em situação inquietante, já que implicará a transferência de controle de decisão para os usuários. Enquanto os profissionais terão conhecimentos diferentes dos usuários, estes por sua vez terão habilidade em identificar 
problemas, porém sem saber como resolvê-los. A colaboração efetiva acontece quando todos os participantes no processo partilham suas idéias e desenvolvem melhor suas aptidões.

Certamente, o envolvimento dos usuários requer mais tempo e tem um custo maior do que contar apenas com profissionais que têm experiência ampla e conhecimento especializado. O tempo e o esforço dedicados ao envolvimento dos usuários é a forma básica de desenvolver organizadamente a comunidade, ajudando os participantes a resolverem conflitos e segurarem os objetivos identificados, para poderem ter uma ampla discussão e dar uma contribuição quase ilimitada a qualquer processo de planejamento.

A falta de experiência adequada dos profissionais, da administração pública e de gerenciadores nos trabalhos para aceitar a colaboração dos usuários têm limitado a efetividade da participação de todos. Um consultor externo pode facilitar o processo participativo e capacitar os profissionais e a administração local.

Freqüentemente as pessoas envolvidas não representam maioria, mas elas são mais que cidadãos que representam algum interesse especial. A participação cidadã tem fraquejado porque a influência dos cidadãos envolvidos no processo tem sido minimizada, e o processo é ineficiente em trazer o cidadão para tomar decisão de fato. Ademais, a participação não é distribuída na sociedade igualmente, porque as qualidades que permitem a alguns participarem - motivação, habilidades, recursos - não são igualmente distribuídas. Os fatores que inibem a participação incluem a esmagadora necessidade individual que sobrepuja a coletiva, o baixo senso de eficácia, e o excesso de burocracia. Essas são as características que mais comumente vêm associadas à pobreza.

Todas as organizações e comunidades experimentam o conflito em algum momento em seu cotidiano. O conflito se instala porque as pessoas enxergam as situações de forma desigual, variam em seus objetivos, e escolhem ações e atitudes diversas. Essas diferenças ocorrem pelos valores que cada um traz consigo, pelas informações desiguais ou ainda porque as informações são processadas de forma diferenciada (LOZARE apud SANOFF, 2000). Associadas ao conflito, por um lado, estão as conseqüências negativas e, por outro, a disputa. O lado construtivo aparece se os participantes desenvolverem procedimentos cooperativos para resolver os problemas.

A mediação dos conflitos reduz a perda de tempo ao refazer algumas vezes as tarefas necessárias, e resulta numa forma mais eficiente de utilizar as fontes. A mediação de conflitos encoraja os envolvidos a ouvirem e a entenderem o ponto de vista de outros presentes, 
reduzindo a monopolização, tornando-as mais confiantes e fazendo-as sentirem-se mais fortes para entender e arcar com as dificuldades, enfrentando diretamente o conflito, ou seja, tendo outros as ouvindo e respondendo a seus anseios, ajuda-as a aumentar a auto-estima (TJOSVOLD apud SANOFF, 2000). Aprender a mediar o conflito propicia bem-estar, assim como efetividade da organização.

A ausência de conflitos indica que foram excluídos os diferentes pontos de vista do processo de tomada de decisão, evitando assim alcance maior de visão do que é possível e, portanto, reduzindo as opções. As desavenças podem ser utilizadas para revelar preconceitos, necessidades e valores, e melhorar as habilidades de interação. Os grupos que aproveitam os conflitos para aprender, em lugar de escondê-los, tornam-se mais coesos.

Indivíduos em situações de conflito freqüentemente precisam de alguma ajuda para esclarecer e ajustar suas diferenças: a assessoria de uma pessoa neutra. A mediação é aplicada para uma variedade de disputas políticas organizacionais, ambientais e públicas. Para que ela ocorra, as partes precisam iniciar o processo de negociação. Em outras palavras, a mediação é uma extensão do processo de negociação, exigindo a presença de um mediador que traz uma dinâmica nova para a disputa. Os problemas associados às dinâmicas negativas no processo de negociação certamente significam falta de confiança e comunicação truncada.

A criação de um espaço de confiança e cooperação vem associada à conciliação, iniciando-se com as partes que estão em disputa uma construção harmônica e de credibilidade, educando os participantes sobre o processo de negociação, e arrancando um compromisso para a mediação do processo. A seguir deve ser selecionada uma estratégia para a solução do conflito, para guiar a mediação, a qual inclui competição, acomodação, assimilação, compromisso de negociar e interesses baseados na negociação. Neste ponto, é importante uma coleta, avaliação e análise de informações iniciais sobre os envolvidos, através de observações diretas, entrevistas, história de vida e outras fontes secundárias, como reportagens, minutas, artigos em jornais, ou histórias contadas por outros.

Com essa base, o mediador deverá desenvolver um plano detalhado para conduzir as discussões dentro do processo, identificando estratégias que irão certamente levar ao acordo, respondendo às questões como quem deverá ser envolvido, o que produzir, quais os procedimentos que serão utilizados, e como os participantes serão educados sobre o processo. As negociações são iniciadas logo após o estabelecimento de algumas regras gerais e diretrizes de comportamento, com facilitação de comunicação e troca de informações. As técnicas de comunicação sugeridas por SANOFF (2000) são a de reiniciar o que foi dito com 
outras palavras; dividir uma idéia em partes menores, resumir as mensagens; organizar as idéias em uma seqüência lógica; generalizar os pontos em mensagens, perguntar para tornar mais claras as idéias apresentadas.

A mediação em que ocorre a definição de questões e cenários é a fase em que são registrados em uma agenda, a nomeação de problemas em termos de grau de importância, para serem discutidos, identificando quais terão maior possibilidade de acordo, para trabalhar com mais detalhes. Nesse processo, os interesses implícitos de disputa deverão ser trazidos à tona de forma sutil. A generalização de acordo requer uma revisão inicial dos interesses de todas as partes, para depois combinar, descrever e modificar as alternativas, para alcançar concordância final de todos. Alcançar um acordo significativo, que resultou de algumas disputas entre as partes, diminui diferenças e, conseqüentemente, elimina conflitos. Nessa etapa ,exigem-se barganhas, requerem-se ofertas, dão-se concessões e oferecem-se acordos.

A combinação de resolução de conflitos com processo de participação pública é um modelo proposto por CONNER e ORENSTEIN (SANOFF, 2000) para difundir uma polêmica quando muitos grupos de cidadãos estão em grande posição de antagonismo para estabelecerem alguma ação. A dissolução de conflitos enfoca uma evolução em compreender, confiar e aceitar, entre, e com as partes envolvidas, juntamente com a assistência do mediador ou facilitador.

A habilidade de construir relações colaboradoras principalmente entre os moradores é a base da futura comunidade, assim como o sucesso de sua organização. A comunicação pessoal é indispensável para estabelecer a interação efetiva e o fluxo apropriado de informações, a base na qual a cooperação é possível para o desenvolvimento de idéias, decisões e estratégias. Para quem chega, o ponto que se destaca é que, para implementar mudanças, precisa-se primeiramente conhecer a cultura organizacional, antes de introduzir técnicas, formas de gerenciar a equipe e envolver seus componentes.

Os elementos da organização que constituem sua cultura incluem as expectativas de como os membros devem se comportar bem, qual a linguagem adotada no entendimento de significados das palavras e dos eventos nas políticas públicas e sociais; o significado simbólico atribuído para o design e o uso do espaço, o olhar e sentido da organização sejam comuns a todos assim como a visão de cenário futuro.

Para a criação de um processo efetivo de design e de planejamento, os profissionais precisam entender como a organização faz suas decisões, em que base essas decisões são 
feitas, e o papel designado por ela para o ambiente físico. A cultura é um determinante crítico de como uma organização está preparada a lidar com a mudança. É a cultura que, em termos de atitude, valores e padrões de comportamento, pode ser transformada para um melhor trato com o ambiente. Organizar esse processo está associado a um planejamento estratégico no qual o mais importante produto é o próprio processo.

\subsubsection{Etapas e Métodos}

Segundo ARNSTEIN (1969), o envolvimento do cidadão no processo de planejamento está dividido em oito fases. A não participação que poderá ser a manipulação e a terapia em que a meta é sensibilizar ou educar o participante; a seguir: a informação e a consulta são fases intermediárias já a caminho para uma participação mais inclusiva; a conciliação ou mediação de conflitos e construção de consenso cabe aos especialistas incluir as propostas sugeridas pelos participantes; parcerias em que o poder é redistribuído através de negociações entre os cidadãos e especialistas, as responsabilidades são partilhadas dos planos e das decisões feitas e; poder delegado, os cidadãos asseguram uma clara maioria de representantes em comitês com poder para tomar decisões; finalmente, o controle do cidadão no qual a participação dele tem grau de poder para decidir, ou seja, tem todo o controle das modificações, inclusive influenciar nas políticas públicas.

Para BURNS (1979) as diretrizes de um processo participativo estão distribuídas em quatro estágios: o primeiro Consciência - envolve a experiência em descobrir ou mesmo redescobrir a realidade de um dado ambiente ou situação. Cada um que toma parte no processo está falando a mesma língua baseada na experiência comum, no campo onde a mudança está sendo proposta (FREIRE, 1980). A seguir, Percepção - como segunda fase depois da tomada de consciência da história do lugar; parte para a compreensão da situação existente, positiva e/ou negativa, no sentido cultural, social, econômico, e ramificações. Significa partilhar entre eles o entendimento, os objetivos e as expectativas de todos os participantes, trazendo seus conhecimentos para o planejamento.

A fase primordial é a Tomada de decisão — em que se trabalha com os passos anteriores para o programa considerado. Nessa fase, os profissionais trabalham com os participantes, levando-os a desenvolverem formas de design da situação idealizada pelos participantes, baseadas em suas prioridades, depois utilizadas como recurso para sintetizarem alternativas e planos finais. 
A Implementação - de maior valor, pois nessa fase a compreensão é maior. Ela é a transformação do desenho para o mundo real, ou seja, o momento de como fazer, onde fazer e quem precisa fazer o quê, as adequações do desenho para as dificuldades do dia-a-dia da construção.

A participação, na questão comunitária, exige sérias demandas e responsabilidades dos participantes e, especialmente, do mediador ou facilitador. Apesar de grupos voluntários organizarem um processo participativo em projetos, sua complexidade técnica requer assistência de profissionais mais treinados e conscientes das implicações de escolha dos métodos. Acrescentados à necessidade em direção à complexidade técnica, os princípios do design e do planejamento precisam ser incorporados na evolução do processo.

Desse modo, sem os procedimentos claramente identificados e apresentados, os grupos comunitários responderão unicamente a uma situação de crise momentânea e passageira.

Os trabalhos voluntários em comunidades freqüentemente não conseguem esboçar, baseado em sua experiência pessoal, o desenlace de um problema ambiental e, muitas vezes, aparecem com soluções que criam imprevistos, e com conseqüências sérias. Portanto, o gerenciamento dos esforços participativos é importante.

As pessoas se afiliarão ao processo com efetividade, se mudanças puderem ocorrer. A participação funciona se elas acontecem e se os envolvidos na experiência tiveram o sentimento de que seus esforços deram resultado. Ao mesmo tempo, uma avaliação do design e do planejamento tradicional é necessária para assegurar que a participação tornou-se mais que a confirmação das intenções originais do profissional.

Os métodos participativos são: o Planejamento Estratégico, que é uma forma de gerenciar, um esforço organizacional para produzir decisões e ações que modelam e guiam o que a comunidade é, o que faz, e por que faz. A estratégia é o ato de mobilizar fontes em torno das metas, cenários de objetivos e prioridades, identificando questões, aprimorando estruturas organizacionais, tendo atitudes, avaliando e analisando resultados; reúne informações e explora as alternativas, realçando implicações futuras das opções selecionadas.

Charrete é um método rápido e intenso que reúne grupos de interesse nos quais os profissionais atuam tanto no projeto como no processo. Dependendo da natureza do objeto final, as ferramentas variam com as escolhas. Geralmente, o processo de charrete amplia a participação nos primeiros três ou quatro dias, consolidando o fundamento para as idéias preliminares do projeto. No final do último dia, há um encontro entre todos os participantes e 
explicação, transferência de conhecimentos, especialmente para as partes atingidas. Existem categorias de charrete que não serão tratadas neste trabalho.

Planejamento de Ação Comunitária - Communnity Action Planning - são iniciativas próprias da comunidade, em uma abordagem que a capacita a desenhar, implementar e gerenciar seus próprios programas espontâneos. Outros desdobramentos, como o desenvolvido pelo Massachusetts Institute of Technology, chamado Planning Assistance Kit - PAK, apresenta uma série de quadros que ajudam o preparo da comunidade para implementar o planejamento e o gerenciamento de sua moradia; e o Take Part, que orienta os cidadãos para se tornarem mais conscientes de um problema, foi desenvolvido por HALPRIN, BURNS e BAUM e, em alguns aspectos, parece com partitura musical.

Pesquisa participativa - processo de fortalecimento que envolve os participantes na busca de informações e de tomada de decisão.

Jogos participativos - técnicas de abstração do problema principal sem as preocupações que tradicionalmente a situação apresentaria.

Oficinas - para interação entre as pessoas com o intuito de facilitar a discussão na etapa seguinte.

Fóruns públicos - encontro aberto que abarca as organizações e as agências para apresentá-la às informações sobre determinado projeto.

Avaliação pós-ocupação - utilizada para identificar o sucesso e as falhas do espaço físico. O método de coleta de informações são: questionários, entrevistas e caminhadas com observações anotadas segundo uma sistemática.

O envolvimento dos moradores em um processo de aprendizagem nas práticas urbanas expressa uma crítica às experiências tradicionais, em favor de métodos que reconheçam e estimulem uma multiplicidade de valores na cidade e no ambiente. Essa abordagem possibilita a valorização de uma perspectiva de clientes com poucos recursos, nos bairros, na periferia e outras populações especiais, sem a completa dependência sob o bem estar social do sistema de serviços. Com esse enfoque sob o estar habilitado a fazer planos se as práticas do design comunitário parecem ser real, possível e gerenciável, pergunta-se, então, se elas têm sido bem sucedidas? Se o sucesso significa tomar o controle das mudanças físicas na comunidade, através do desenvolvimento das forças políticas e econômicas, então, o sucesso tem sido e continua marginal. 
Por outro lado, as práticas participativas não estão prontas para fazer tantas mudanças, mas sua permanência e sucesso dependerão de sua capacidade de organizar arranjos entre algumas combinações das tarefas apresentadas anteriormente e de desenvolver uma estratégia que é tão justa quanto é pragmática. 


\title{
3. Construindo o objeto de estudo: a experiência Caranguejo
}

\author{
“O indivíduo é capaz de desenvolver-se. \\ Mas é no convívio com os outros que ele consegue encontrar soluções \\ para continuar o seu próprio desenvolvimento e contribuir para o desenvolvimento ao seu redor" \\ Rudolf Steiner
}

\subsection{A lógica de ocupação de Salvador no contexto dos assentamentos espontâneos.}

Depois da falência do sistema de capitanias hereditárias como modelo de colonização, D. João III adota o sistema de Governo Geral, cabendo a Tomé de Souza a posse da povoação de Pereira Coutinho. As características topográficas facilitaram a escolha da "fortaleza forte”, onde os princípios gerais eram o da defesa e o da administração; um lugar naturalmente defensável e seguro, com características de acrópole, ou seja, geograficamente estratégico, um promontório compreendido entre a Barroquinha e o Taboão, próximo ao mar, margeando uma escarpa natural rochosa, de sessenta metros de altura sobre o mar, tornando impossível seu acesso. A cidade de Salvador foi a primeira capital do Brasil, no período entre 1549 e 1763, portanto durante 214 anos, e continha em seu traçado estabelecido no núcleo inicial, local onde hoje é a Praça Municipal, um tablado xadrez de ruas e becos que se comunicava quase de um extremo a outro em linha reta por duas vias: uma via sobre a cumeada ao alto, e a outra encostada ao paredão em frente à Baía de Todos os Santos.

A visão da cidade, até o final do século XVI, portanto 50 anos após a sua fundação, e com uma população de 2.000 habitantes, era a de uma única rua que dava acesso ao porto, encostada na base da escarpa em frente à Baía de Todos os Santos e, sobre a cumeada, o Centro Administrativo. Nele havia a Casa de Câmara e Cadeia e a Casa do Governador, com o Pelourinho ao Norte, a atual Praça Castro Alves ao Sul, a Leste a baixada onde passava o Rio das Tripas, entre a primeira e a segunda linha de cumeada, onde hoje se situa a atual Baixa dos Sapateiros e, finalmente, a Oeste, a Baía de Todos os Santos. Essa paisagem permanece até início do Século XVII, quando a ocupação dos equipamentos religiosos e militares se expande além dos limites oficiais. As linhas de cumeadas foram seguidas ao Norte pelo Convento do Carmo, ao Sul pelo Mosteiro de São Bento e a Leste pelo Convento do Desterro. Na linha do mar, os fortes: Monte Serrat, Itapagipe e Santo Antônio da Barra, protegendo as aglomerações em crescimento.

Nessa lógica de ocupação espontânea são formadas dez paróquias, ainda mantidas as funções administrativas e comerciais nos centros originais. A Cidade Baixa abrigava principalmente as atividades comerciais, tendo como limites ao Sul a Basílica de Nossa Senhora da Conceição da Praia, e ao norte a Igreja Nossa Senhora do Pilar, com uma única 
extensão oferecendo todo o tipo de comércio e serviço demandado pela cidade, comercializando desde frutas, legumes, pescados, a escravos, e prestando serviços de transporte portuário, de alfaiate, sapateiro, consolidando a paisagem da época, de que a rua era também um espaço de lazer e trabalho. Havia uma convivência harmoniosa sem que resultasse em uma conformação espacial estratificada como se verifica nos dias atuais.

A população freqüentava a Cidade Baixa, onde os comerciantes importantes e os estrangeiros circulavam e trabalhavam no mesmo espaço que o restante da população, era composta de negros, brancos e mulatos. A maioria das habitações situava-se nas cumeadas, embora muitos comerciantes preferissem morar na parte dos fundos das casas comerciais. Nessa época, iniciam-se sucessivos aterros na zona do porto, estendendo-se até a Península de Itapagipe, que termina por perder sua característica como tal.

No final do século XVIII, a Cidade de Salvador começa a sentir os reflexos de uma ocupação espontânea e sem ordenamento cuidadoso. Os primeiros desmoronamentos acontecem nessa época, os alicerces da Igreja São Pedro dos Clérigos - demolida em 1920, onde antigamente funcionava o Cinema Excelsior na Praça da Sé - ruíram, arrastando dezenas de casas da Ladeira da Misericórdia.

Em meados do século XIX, consolidam-se duas ocupações residenciais: a Penha, que em função da concentração da indústria têxtil assume um caráter popular, fixando ali a mãode-obra das fábricas, vetor de expansão onde se insere nosso estudo de caso, e a Vitória, como reduto da aristocracia comercial, contrapondo-se às ocupações ao norte e à sua população cada vez maior - que começa a se formar com grande contingente de pobres oriundo dos escravos livres.

Assim como a cidade Baixa, a Cidade Alta também convivia com a sujeira e a falta de infra-estrutura: Higiene e salubridade só vão despertar a consciência da população em razão do surto de febre amarela em 1849/50 e do cólera-morbo de 1855 a 1857. É dessa fase o grande crescimento demográfico que, com base no Censo Eclesiástico, passa de 45.600 habitantes em 1805, para 129.109 habitantes em 1872, pelo censo do IBGE.

Aumentam as fontes geradoras de resíduos e a demanda por serviços de saneamento público, quantidades incompatíveis com soluções caseiras que até então vinham sendo usadas pela população. Nesse final de século, inaugura-se uma nova fase de modernização, cujos 
elementos estruturantes são determinados pela salubridade, fluidez e estética. Como reflexo desses elementos, em face da inexistência de legislação específica e abrangente que respaldasse as novas ações, surge o conflito entre os empresários responsáveis pelas desapropriações para implantação das vias e o poder público, na divisão das contas pelas novas obras de alargamento e calçamentos de vias, e os conflitos de interesses entre empresários e usuários. Do ponto de vista estético, a cidade se desdobra na "domesticação da natureza dentro de uma perspectiva paisagística"13, preconizando a regularização do uso dos espaços públicos e a idéia de limpeza da cidade, através da 'eliminação' dos pobres e da utilização de obras de arte e da cenografia. Entretanto, esses investimentos ficaram limitados aos bairros habitados por moradores mais abastados, enquanto os bairros populares e distantes permaneceram sem higiene e com salubridade.

\subsubsection{A favela na cidade e a cidade na favela}

As primeiras manifestações de moradia precária remetem ao período que compreende a segunda metade do século XIX e as três primeiras décadas do século XX. É o período de urbanização/industrialização, de mudanças de ordem econômica, social, política, cultural, espacial. Entre elas, destacam-se a substituição do trabalho escravo pelo assalariado, a formação de mercados e a mercantilização de bens, a decadência do café, o desenvolvimento dos setores secundário e terciário da economia, as migrações, a definição de novas elites no poder, com a queda do Império e a proclamação da República. O crescimento urbano foi intenso (235.000 habitantes em 1870, 522.000 habitantes em 1890) e criadas modernas infraestruturas urbanas e serviços públicos.

Um grande contingente de pobres buscava meios de sobrevivência na área central, onde se concentravam moradia e trabalho e fervilhava a vida urbana. Nessa época, a estrutura urbana se resumia na aglomeração de atividades e populações em torno do núcleo, em que se multiplicavam as moradias possíveis para essa população: os cortiços, a exemplo do Pelourinho, Santo Antônio, Baixa dos Sapateiros e adjacências.

Essas áreas eram moradias de aluguel diminutas e precárias, geralmente superlotadas (6 a 8 pessoas por um ou dois cômodos de $16 \mathrm{~m} 2)^{14}$, sem iluminação e ventilação natural, com instalações sanitárias nos quintais. Essas casas antigas podiam ser oriundas das transferências

\footnotetext{
${ }^{13}$ Fernandes, Ana e Gomes, Aurélio (1992) Idealizações Urbanas e a Construção da Salvador Moderna In: Cidades \& História Grafia UFBa.

${ }^{14}$ Acioly \& Forbes (1998), Densidade Urbana. Na antiga URSS, normas estabeleciam 5 a $7 \mathrm{~m}^{2}$ por pessoa. Nas cidades satélites de Brasília, por exemplo, a norma é de $3 \mathrm{~m}^{2}$ por habitante.
} 
dos antigos moradores, que, mais abastados, buscavam outras tipologias habitacionais, em consonância com os pressupostos sanitaristas que norteavam a escolha dessa classe. As más condições desse ambiente eram associadas à deterioração da saúde e à decadência moral das classes trabalhadoras. Com o agravamento das condições sanitárias da cidade, as habitações coletivas, que chegaram a abrigar entre $20 \%$ e $25 \%$ da população (Vaz, 1985), foram consideradas uma das causas da insalubridade, e condenadas a desaparecer, substituídas por moradias higiênicas.

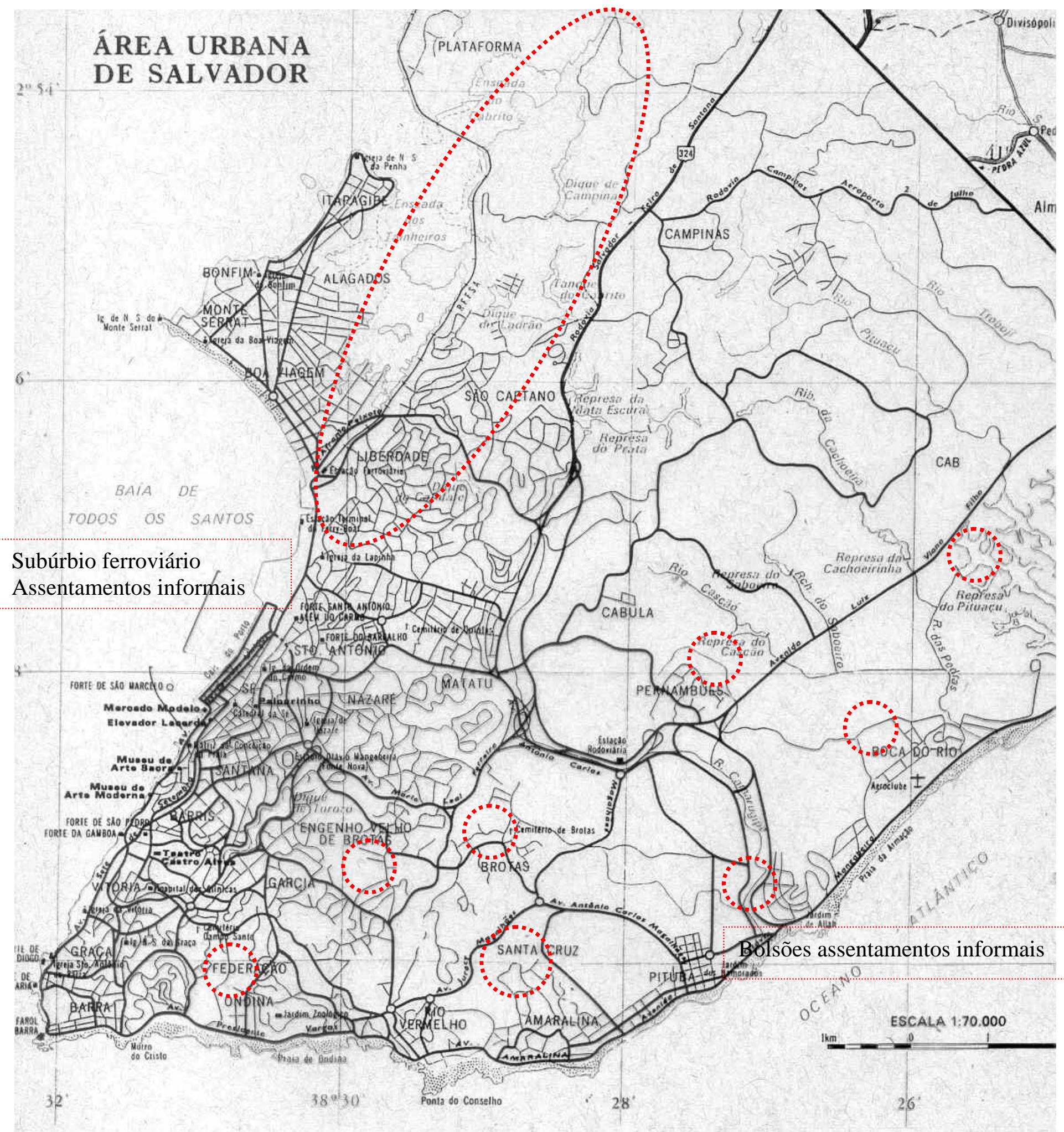


As novas habitações surgidas com essa preocupação foram construídas nas áreas de expansão da cidade, mas seus custos eram proibitivos aos pobres, que permaneceram nos cortiços até que a Reforma Urbana de 1902/1906 os expulsou violentamente. Nesse processo de modernização urbana, a ação do Estado, através da reforma e da legislação urbanística, reforçadas pela ação do mercado imobiliário formal, promoveu o desaparecimento dessa forma tradicional de moradia popular e apontou à maioria da população o rumo que eles próprios deveriam tomar. Para a população de recursos modestos, a direção dos subúrbios, e para a população sem recursos, a direção das encostas.

A partir da década de 40, começam a surgir as primeiras invasões de terrenos baldios, como o caso da famosa Corta Braço, localizada no atual bairro do Pero Vaz, no miolo, e a Invasão dos Alagados, encabeçada pelo próprio poder público ao acostar parte do mangue e implantar aí o aterro sanitário da cidade. A especulação imobiliária impulsionou ainda mais o deslocamento das camadas da população com poucos recursos para áreas suburbanas, onde o solo ainda não era tão valorizado e onde havia um importante meio de transporte que servia de atrativo na ocupação, o trem do subúrbio implantado em 1870, com a finalidade de escoar as mercadorias do Recôncavo. O resultado desse processo de ocupação foi uma área marcada pela segregação da elite, junto do centro, e outra pela segregação da classe operária, no subúrbio ferroviário.

Ainda no início desse século, os subúrbios se tornaram proibitivos para os mais pobres, que passaram a construir seus barracos precários nos vazios urbanos. As encostas, que já apresentavam vestígios de moradias rústicas desde o final do século XIX, foram aos poucos ocupadas, delineando-se as primeiras favelas. Essas se expandem rapidamente nos terrenos desocupados e sem interesse para a construção imobiliária.

A partir dos anos 30, com o crescimento populacional intenso, o processo de favelização se acentuou e se expandiu, acompanhando as principais fontes de emprego para a população de baixa renda: o industrial, na direção das áreas industriais na borda da Baía de Todos os Santos, formando uma grande extensão de população com poucos recursos e condições precárias de moradia e serviços domésticos, e da construção na Borda do Oceano Atlântico, junto dos bairros litorâneos burgueses, conformando grandes bolsões de assentamentos informais.

Apenas em meados do século XX é que se problematiza novamente a questão da habitação popular, tendo então como eixo a favela. Esse padrão de habitação auto-produzido caracteriza-se pela sua ilegalidade em termos jurídicos e sua irregularidade em termos 
urbanísticos (Milton Santos, 1987), além da precariedade e da insalubridade. Quando não pôde mais ser negada, sua existência foi considerada uma “chaga” que deveria ser extirpada, e seus moradores, removidos. A política de remoção fez com que, de 1960 a 1980, cerca de 146.00 pessoas fossem transferidas para grandes conjuntos habitacionais (Santos, 1984). Somente com o processo de redemocratização do país, a partir da promulgação da Constituição Federal em 1988, as propostas de urbanização, que os favelados reivindicavam desde muito, foram incorporada às políticas federais.

Um novo padrão de habitação popular se manifestava, à grandeza que a expansão urbana ultrapassava os limites do município, configurando-se como área metropolitana. $\mathrm{Na}$ proporção que as favelas esgotavam os espaços disponíveis no interior do tecido urbano, as alternativas para a população de baixa renda confinavam-se às periferias cada vez mais distantes onde, a partir dos anos 50, multiplicaram-se os loteamentos populares: lotes pequenos, sem infra-estrutura urbanística, de difícil acesso e, por isso mesmo, baratos.

A própria política habitacional de remoção de favelas e construção de conjuntos em áreas baratas e distantes do centro incentivava o processo. A combinação loteamento popular/auto-construção tornou-se padrão metropolitano de habitação popular, assim como a ocupação das periferias se tornou o padrão de urbanização.

No entanto, a expansão das periferias não significou o estancamento do crescimento das favelas no interior do município. Esse crescimento de favelas é devido em maior grau à pauperização do que à migração. No seu interior, há grande heterogeneidade: novas práticas, novas tendências e novos padrões de habitação popular podem ser identificados.

Como aparentemente não há mais espaços que possam comportar novas favelas no interior do núcleo, onde a permanência das existentes está praticamente assegurada, algumas tendências podem ser observadas: novas favelas na periferia, por um lado, e o adensamento e a verticalização das antigas e consolidadas, por outro. ${ }^{15}$

\subsubsection{Bairros periféricos feitos à mão ${ }^{16}$.}

O desbravamento das áreas onde hoje estão os subúrbios de Salvador é processo muito antigo, contemporâneo à colonização, quando os primeiros colonos procuravam construir seus

\footnotetext{
${ }^{15}$ Estudo do Uso e Ocupação do Solo para subsidiar a revisão do Plano Diretor de Desenvolvimento Urbano e Ambiental de Salvador (2000). Coordenadores: arquitetos Carl von Hauenshild e Nagírley Kessin.

${ }^{16}$ Título do texto de Maria Brandão, professora de Sociologia no mestrado de Engenharia Ambiental da Universidade Federal da Bahia.
} 
engenhos e currais à margem dos “caminhos da água” — o mar e os rios —, pela facilidade de acesso e escoamento da produção; as vias terrestres, nessa época, eram pouco importantes, simples “estradas de boiadas”.

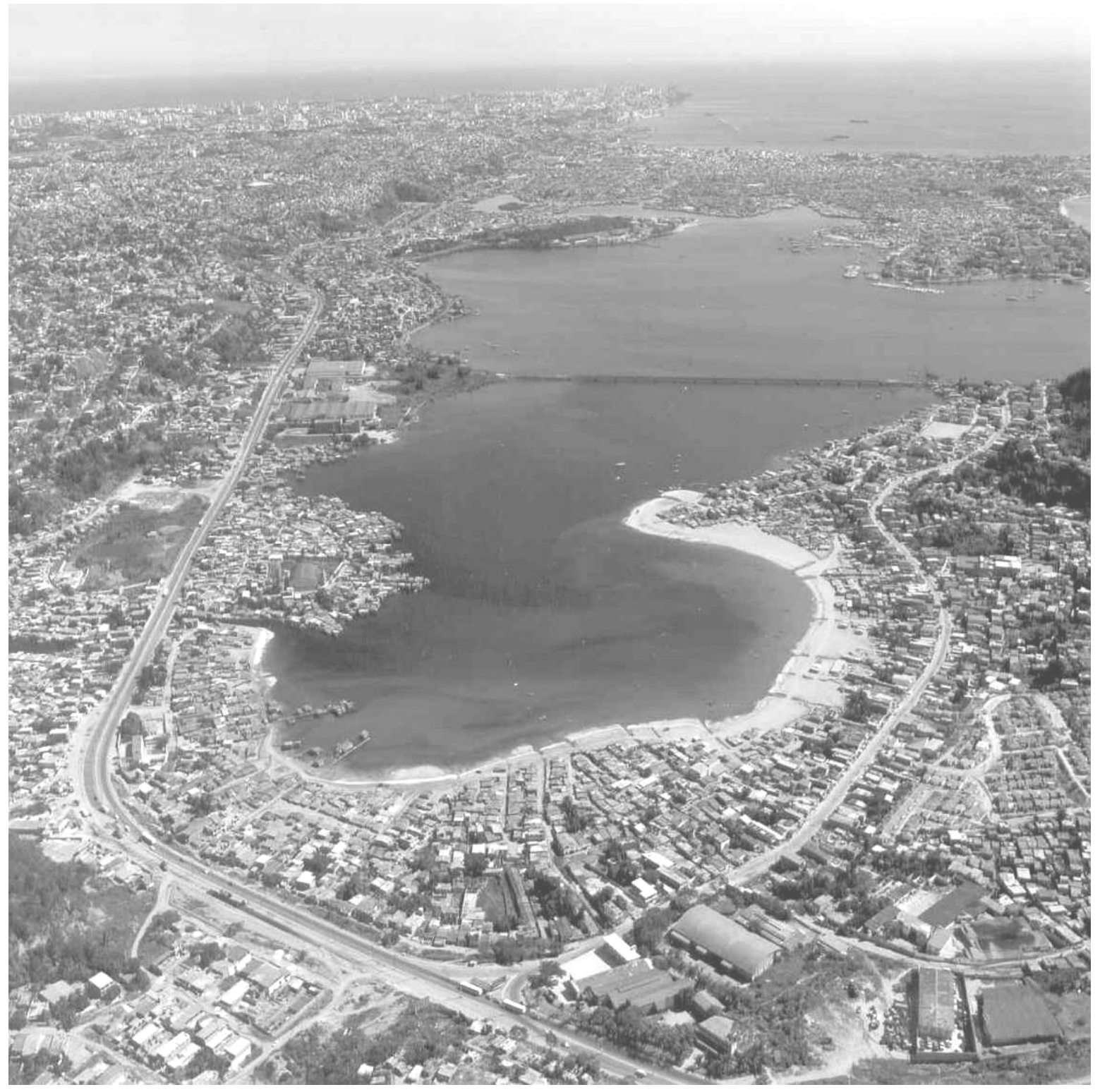

Com o crescimento de Salvador, houve ampliação de suas funções urbanas e da zona suburbana, principalmente de veraneio ou de comunidades de pequena classe média, instalada ao redor da Baía de Todos os Santos, até às vizinhanças da Baía de Aratu. Tornou-se o subúrbio uma região aprazível, com chácaras, agricultura de subsistência e fruticultura, pesca, mariscagem, cujos núcleos habitacionais ligavam-se à cidade pela ferrovia, implantada a partir de 1863, ligando Salvador a Alagoinhas, depois à Feira de Santana e à Cachoeira.

Outro momento que impulsiona novas mudanças é o da inserção da economia baiana no contexto das modernizações industriais, tendo em vista que aumentaram as ligações de Salvador com outras regiões através do fluxo de mercadorias, de capitais e de idéias. Essa 
rede de ligações tornou-se viável através da via férrea existente e pelos transportes marítimos. É nos moldes dessas modernizações que a indústria têxtil se instala nas áreas suburbanas e se articula com outros elementos já existentes no local, provocando o surgimento dos atuais bairros.

A partir dos anos 30, as atividades petrolíferas, com a instalação da Refinaria de Mataripe, trazem novas perspectivas para a economia regional e, conseqüentemente, para a capital baiana, posto que as atividades de implantação, produção, circulação, distribuição e consumo conseguiam aglutinar tanto o Recôncavo quanto Salvador, na esfera produtiva.

Dessa forma, a capital era local de concentração das empresas que prestavam serviços à refinaria, onde morava parte dos funcionários da empresa, e também era o mercado distribuidor de produtos não existentes nas cidades do Recôncavo. Por outro lado, as atividades petrolíferas atraíram uma série de indústrias, derivadas de incentivos fiscais e financeiros fornecidos pela SUDENE e pelo BNH, o que veio a proporcionar o amadurecimento do parque industrial da Bahia.

As conseqüências no nível espacial foram mudanças nas funções das áreas centrais, tendo em vista que a burguesia começa a deixar as áreas próximas ao Pelourinho/Maciel, cedendo espaço para o comércio e outros serviços, e facilitando a ocupação, pela população de baixa renda, dos casarões anteriormente ocupados por ela. A classe dominante, então, dirigiu-se para os bairros de cumeadas da Vitória, Barra, Graça e construiu casarões de luxo, dando um novo aspecto à cidade.

Mas a expansão não pára por aí, pois a “expansão da mancha urbana já atingia pela via oceânica, em estreita faixa, a área de Amaralina, antiga zona de pescadores e de veraneio, passando pelo Rio Vermelho e Ondina”. Igualmente, na direção da Península de Itapagipe, a ocupação urbana se adensou até Paripe e, a partir daí, foi-se estabelecendo de forma pontual, em torno das estações ferroviárias suburbanas.

Envolvendo o núcleo central, a mancha urbana se expande significativamente por outras áreas, algumas com poucos recursos, como o núcleo da Liberdade, de São Caetano, de Matatu, de Brotas e da Federação, quase sempre ocupando cumeadas e posteriormente as encostas e os vales. Em muitos deles, havia atividade hortigranjeira. Fica claro o quanto o espaço urbano de Salvador já estava extenso, alcançando áreas até então desabitadas e já apresentando forte diferenciação do uso do solo residencial. 
É importante destacar que, aliadas à dinâmica extensão urbana depois da década de 40, começam a ser planejadas e construídas as avenidas de fundo de vale, permitindo uma maior ligação do centro com as áreas mais distantes. Assim foram construídas a Avenida Vasco da Gama e Avenida Centenário, ao mesmo tempo em que foram desativados os bondes urbanos, em 1961, que serviam à cidade até aquele momento. A partir de então os ônibus passaram a predominar no transporte urbano da cidade.

\subsubsection{Histórico de ocupação e constituição da comunidade Baixa do Caranguejo}

Situado no Bairro do Lobato, foi o primeiro ponto do território nacional onde se constatou efetivamente a existência de petróleo, quando havia interesses externos e internos em negar essa riqueza ao Brasil. Na história do petróleo no Brasil, apresentada pela Petrobrás, esse primeiro poço sequer é mencionado, sem importância econômica, segundo justificativa da própria instituição.

As novas atividades econômicas que surgiram a partir da década de 60 foram marcadas pelos avanços da industrialização subsidiada pelo poder público, que gerou o CIA - Centro Industrial de Aratu, cujo acesso se dava inicialmente através da Avenida Afrânio Peixoto, mais conhecida como Avenida Suburbana. Nos anos 70 inicia-se outra etapa do desenvolvimento da RMS - região metropolitana de Salvador que, em alguns momentos superpõe-se à anterior: é quando se instala o COPEC - Complexo Petroquímico de Camaçari. As mudanças em Salvador e no seu entorno foram ainda mais substanciais, refletindo-se em toda a sua economia, sociedade e traços culturais. O crescimento populacional era muito alto, embora o peso das migrações fosse inferior ao das décadas anteriores. A força de trabalho no setor formal crescia, mas também se constituía um grande setor informal. A essa população colocada nos estratos mais baixos da população faltava quase tudo normalmente associado a uma sobrevivência digna, desde um emprego garantido que permitisse uma renda adequada, até a habitação.

A questão da moradia, com a expansão de Salvador aliada à falha permanente da atuação dos poderes públicos, agravava cada vez mais a situação dos segmentos populacionais de mais baixa renda. Como eles não dispunham de condições para entrar no mercado da habitação, mesmo nos seus mais baixos níveis, a ocupação periférica tornou-se a forma principal para solução da habitação. Intensificada desde os anos 60, na década de 70, muitos dos subúrbios ferroviários foram palco de invasões: Praia Grande, Plataforma, Lobato, Alto da Terezinha, Escada, Coutos, Paripe, Beira Mangue, Bambu. Mais tarde a de Lobato 
espalhou-se pela área do Pontilhão, praticamente dando os contornos da área onde se insere nosso estudo de caso.

Nesse período da expansão econômica de Salvador foram implantados os grandes projetos viários na cidade e na sua comunicação com o entorno. Datam do pós-64 muitas das grandes avenidas, entre elas a Avenida Afrânio Peixoto - Suburbana. Com a sua implantação, o papel de bolsão de população de baixa renda dos subúrbios ferroviários se intensificou, e acabaram-se de uma vez os aspectos bucólicos do passado que porventura ainda existiam.

Se as invasões das décadas anteriores eram grandes movimentos coletivos, elas diminuem seu ritmo e tomam outra conotação, passam a ser paulatinas, com sucessivas etapas de expansão, em função da maior ou menor vigilância e repressão sobre a terra. Em Lobato, pode-se observar esse fenômeno, quando sucessivos trechos são ocupados.

A compreensão de como ocorriam as invasões ajuda a entender a lógica dos seus habitantes. Segundo estudos do período ${ }^{17}$, a resistência passiva foi uma tática importante para a sobrevivência das áreas invadidas: não desistir, aguardar o melhor momento para dar continuidade à invasão, reconstruir a cada destruição. O procedimento de invadir envolvia uma série de expedientes. A ajuda dos que primeiro armavam seus barracos e da população vizinha, quando também pobre, era de grande importância, pois acelerava a ocupação e auxiliava a burlar a vigilância da Polícia Administrativa e a evitar a demolição dos barracos. Desenvolvia-se, assim, toda uma teia de solidariedade que sempre foi fundamental para a permanência das invasões e que, no caso em estudo, foi perfeitamente identificada em campo. Ao que indicam estudos recentes, ainda é característica essa forma de ocupar a terra para essas populações.

Outra forma de acesso à habitação popular eram os loteamentos irregulares que, junto com as invasões, levaram à ocupação da periferia da cidade. Nos subúrbios ferroviários ocorreram muitos deles: em Coutos, Periperi, Paripe, Plataforma. A demanda por serviços urbanos nesses assentamentos era muitas vezes sanada pela própria população, de forma provisória e rudimentar, sendo posteriormente transformada em reivindicações para provocar a intervenção do Estado.

Uma avenida cercada por alta densidade de habitações precárias, um comércio de sucatas, construções erguidas em áreas de risco, falta de obras de contenção de encostas,

\footnotetext{
17 Ver especialmente Mattedi, M.R.M. As Invasões em Salvador. Dissertação apresentada ao Mestrado em Ciências Sociais da UFBa., 1978.
} 
esgotos a céu aberto, avanços sobre o mar por aterros inadequados, poluição das praias e destruição dos manguezais, acessos difíceis, esse foi o destino das bucólicas áreas de veraneio. O transporte ferroviário perdeu quase totalmente a sua importância, pois as ligações interbairros por ônibus se tornaram mais convenientes para essa população que ganha a vida espalhada por toda a cidade.

Os últimos anos acirraram esses aspectos, da crise econômica dos anos 80 e da recessão de emprego da década de 90, que ainda hoje permanece; surge cada vez mais uma população em situação de desamparo para abrigar, à qual começam a se acrescentar os segmentos empobrecidos da antiga classe média, atingidos pela sucessão interminável de planos econômicos “milagrosos”.

Não bastasse esse cenário, as grandes intervenções anunciadas pela administração pública, tais como Baía Azul, Viver Melhor e Ribeira Azul, vêm sendo executadas desprestigiando seus moradores fundadores. Como reforço para esse quadro caótico, há falta de metodologia para avaliação dos impactos sociais e físicos dessas intervenções nos seus aspectos qualitativos.

A característica desses assentamentos informais varia de acordo com a disponibilidade dos materiais, os recursos financeiros da população, o potencial de ocupação, e perspectiva de continuar no local. Os tipos de favela tomam diferentes formas dependendo do dono do barraco.

ABRAMS (1964) classificou esses assentamentos em: a) dono invasor do seu próprio barraco, mas não do solo, se o invasor levanta o barraco no único pedaço de terra disponível, que pode ser em terras públicas ou em terras cujo dono está ausente. Segundo o mesmo autor, essa é a forma mais representativa de invasão; inquilino invasor, que é o mais pobre, não é o dono do barraco ou o construiu, mas paga o aluguel para outro invasor; muitos imigrantes iniciam nesse status, esperando uma oportunidade de se transformar em proprietário invasor; e invasor duradouro, que ultrapassa sua permanência mais do que o acordado, e/ou parou de pagar o aluguel e o locador tem medo de ser despejado. O invasor locador é um invasor de longo período e tem espaços ou barracos para alugar com preços exorbitantes. O invasor cooperador é parte do grupo que compartilha o todo invadido, protegendo-o contra intrusos públicos ou privados. 


\subsubsection{Elementos da paisagem}

O local onde se instalou a favela do Caranguejo corresponde a uma área formada por depósitos quaternários, bordejando a falésia da falha de Salvador em que estão presentes os ambientes associados a formações marinha arenosas (terraços marinhos), sobre os quais se instalaram cursos d’água que foram seccionados pela via férrea - 1860 - e pela avenida suburbana - 1964. Um detalhamento desses ambientes permite delimitar quatro subunidades ambientais que condicionam a qualidade de vida dos moradores locais e, por sua vez, devem nortear qualquer intervenção urbanística necessária para melhorar a qualidade vida de seus moradores.

A unidade do manguezal localiza-se na porção extremo leste e corresponde a áreas influenciadas diretamente pelas marés, que penetram via bueiro ao longo da ferrovia, fazendo com que as condições de drenagem sejam dificultadas. Essas áreas ficam permanentemente inundadas, gerando problemas para as ocupações aí instaladas. A presença de solos hidromórficos, lamosos e ricos em matéria orgânica, apresenta baixa resistência às fundações de obras civis. Os pântanos a montante dos manguezais bordejam a Avenida Afrânio Peixoto, ocupando o fundo do vale. Nessas áreas, a influência das marés é menor, porém a superficialidade do lençol freático faz desse ambiente uma área sazonalmente alagadiça.

A unidade dos terraços arenosos representa uma declividade acima de $15 \%$ sobre sedimentos arenosos que fazem contato com os solos hidromórficos associados aos pântanos e brejos. A proximidade no nível freático, coligado à elevada permeabilidade dos sedimentos arenosos, dificulta a utilização de sistemas tradicionais de esgoto tipo fossa séptica, em virtude dos riscos de contaminação das águas subterrâneas, decorrentes da infiltração dos efluentes. A última unidade são os topos planos dos terraços arenosos, áreas aplainadas dos terraços arenosos, com declividade inferior a 5\%.

A visão dos moradores é detalhada apenas por aqueles mais antigos. São eles que trazem a percepção da paisagem com mais consciência porque as transformações foram significativas. Os elementos preponderantes existentes no passado da ocupação eram as nascentes, a presença de áreas de mangue. Tais elementos foram sendo substituídos primeiramente pela interferência da administração pública: as estrada de ferro em 1860; o aterro para instalação da subestação em 1940; a construção da avenida em 1960 e a passarela em 1980. A seguir, os sucessivos aterros para criação de solo para a moradia das pessoas que não tinham acesso ao mercado formal imobiliário. E, finalmente, a urbanização da favela em 1999, reduzindo drasticamente o restante das massas de vegetação e as poucas iniciativas dos 
residentes nos espaços de convivência coletiva. Os fatos históricos e econômicos foram motivos para a chegada de grande leva de pessoas imaginando melhores oportunidades. Conta o representante da comunidade que chegou por lá na década de 40. No início, a maior parte do terreno era de mangue; nas marés de cheia, o mar chegava até o pé da escarpa, passando embaixo da pequena ponte da linha de trem; o mar já não conseguia avançar além do limite dos trilhos; vieram os primeiros aterros em meados dos anos 60. Outra moradora conta que as primeiras casinhas começaram na margem da avenida, depois, com sucessivos aterros, foram conquistando cada vez mais uma parte no mar.

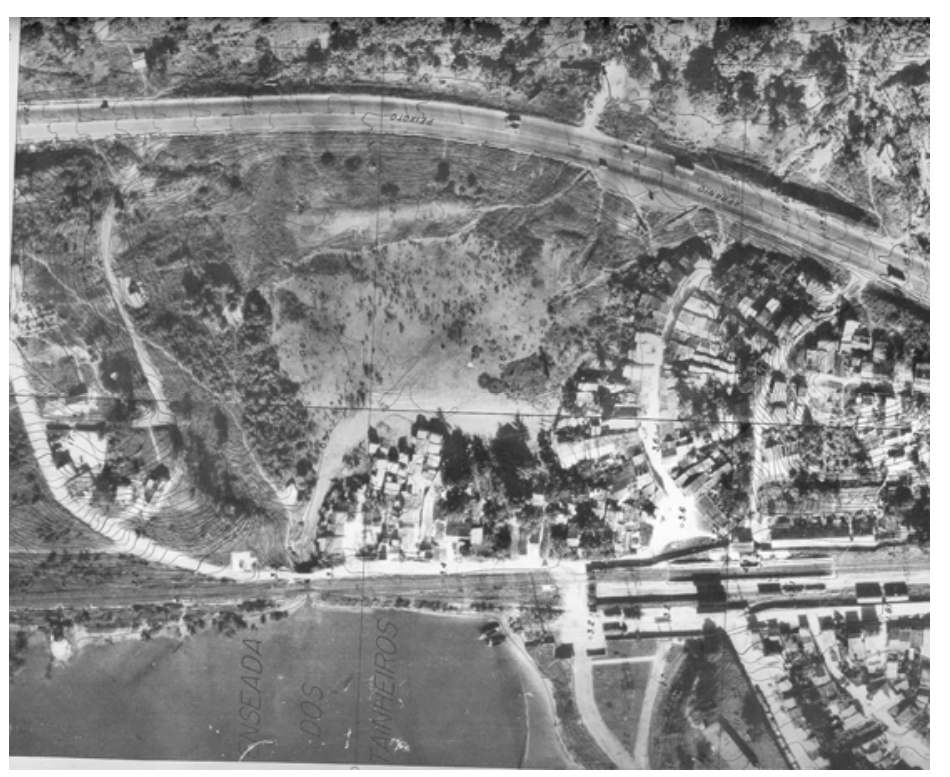

\section{3}

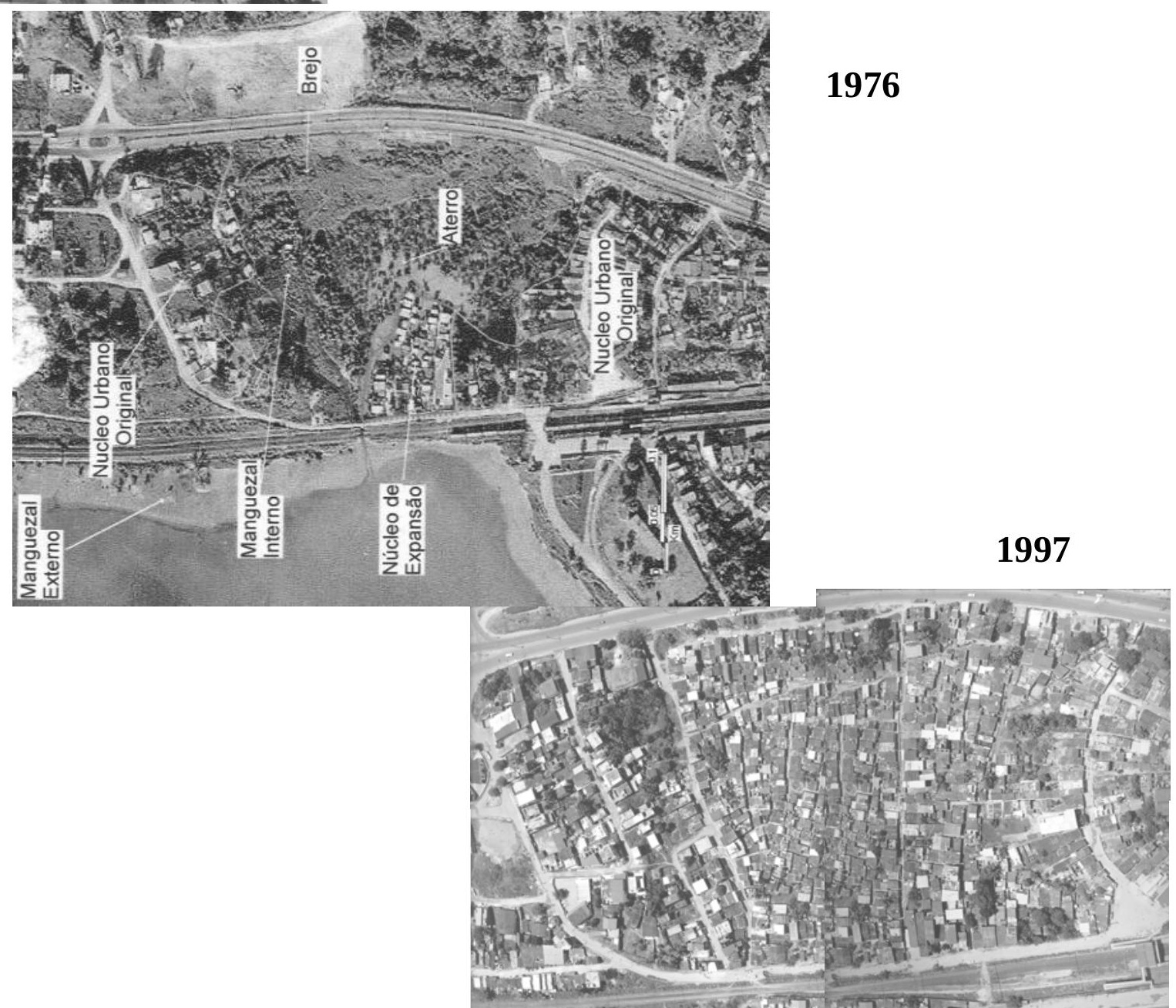




\subsection{O concurso público e os documentos legais}

Em 10 de dezembro de 1996, o Conselho Curador do Fundo de Garantia por Tempo de Serviço, através da Resolução 249, utilizando recursos, não mais a fundo perdido, mas de um poderoso elemento de melhoria das condições de habitabilidade dessas populações, estabelece eficazes métodos de intervenção, adequados aos valores de participação popular.

O Ministério do Planejamento do Governo Federal apresentou o programa PRÓMORADIA, para atender às famílias que se encontravam na faixa salarial de até três salários mínimos. No Município de Salvador, com base no levantamento do censo do IBGE de 1999, elas representam mais de $68 \%$ da população total. No estado da Bahia, o programa foi denominado VIVER MELHOR, gerenciado pela instituição estadual, extinta em 1999, a URBIS - Habitação e Urbanização da Bahia. Em 2000, passou a fazer parte de um único órgão - Companhia de Desenvolvimento Regional da Bahia - CONDER, com recursos administrados pela Caixa Econômica Federal.

Em março de 1997, o Instituto de Arquitetos da Bahia, juntamente com URBIS Habitação e Urbanização S/A —, órgão responsável pelas políticas públicas de habitação e urbanização em todo o estado da Bahia, e com a SRHSH — Secretaria de Recursos Hídricos Saneamento e Habitação, organizou um Concurso Público Nacional para propostas de intervenção urbana em seis áreas de assentamentos “subnormais” no município de Salvador.

O promotor do Concurso foi a SRHSH, com a interveniência da URBIS. As obrigações, responsabilidades e prerrogativas, condições e contrapartidas do promotor estavam estabelecidas em contrato administrativo de acesso restrito, celebrado entre a SRHSH e o Instituto dos Arquitetos Bahia. Essa entidade ficou responsável pela formação da equipe julgadora, além de elaborar um sistema de esclarecimento de dúvidas de interpretação do Edital.

No edital e anexo estavam descritas as normas para a realização do concurso, para equipes preferencialmente multidisciplinares, coordenadas, obrigatoriamente, por arquiteto ou urbanista, Foram selecionadas propostas urbanísticas e metodológicas, no plano de idéias, para a urbanização de seis áreas faveladas em Salvador.

As idéias foram apresentadas através de oito painéis de 594 x $420 \mathrm{~mm}$, dispostos no sentido horizontal, e de um relatório da metodologia de, no máximo, 20 páginas, formato A4, encardenado. Para as soluções urbanísticas coube peso 7 e para o relatório metodológico, peso 
3, observados grau de objetividade, criatividade e exeqüibilidade, tecnologia aplicada e adequação ao meio ambiente.

As equipes selecionadas para cada uma das seis áreas foram premiadas com a contratação para a elaboração do projeto executivo de urbanização, entendo-se por urbanização a implantação e/ou complementação da infra-estrutura, equipamentos e serviços urbanos indispensáveis ao funcionamento normal de qualquer aglomeração urbana, propiciando melhoria nas condições ambientais e de vida da população residente. Para o desenvolvimento do projeto constaram, além dos equipamentos coletivos como praças, creches, escolas, posto de saúde e sede da associação, projeto geométrico das vias, sistema de drenagem, redes e serviço de esgotamento sanitário e abastecimento de água, iluminação pública, bem como projetos das novas unidades habitacionais, as consultorias em sondagem, topografia, exceto o projeto social.

Enquanto as outras equipes optaram por uma metodologia geral para todas as seis áreas, e, portanto, inscreveram-se nessas seis áreas, nossa equipe selecionou unicamente a Favela do Caranguejo, destacando a importância em apreender detalhes a serem incorporados no método participativo, dando mais ênfase ao envolvimento da população do que à questão tecnológica do projeto de desenho urbano.

O projeto social era responsabilidade da equipe de assistentes sociais da URBIS, e ficou completamente dissociado do projeto de desenho urbano apresentado pelas equipes. $\mathrm{O}$ conceito de participação, descrito na resolução, validando a obtenção dos recursos, foi diferente do adotado nesse trabalho que, para os moradores, não passou de tentativas para solução individual de problemas simples e corriqueiros. Para esta pesquisa, não analisaremos o projeto social aplicado pelo poder público.

As informações secundárias para o conhecimento prévio da favela estavam disponíveis no Instituo IAB Bahia, além de mapas, e algumas publicações de outras experiências em urbanização de favelas, a exemplo do programa Favela Bairro da prefeitura do Rio de Janeiro. Os mapas em exposição no Instituto dos Arquitetos eram mapas restritos apenas à área, onde não foi considerado o entorno em sua proximidade com o mar numa borda recortada voltada para a Baía de Todos os Santos, conferindo-lhe características peculiares de entrada e saída de pequenos estuários, além de sua inserção no município, com predominância de assentamentos precários. 
Nossa equipe foi premiada e contratada para desenvolver o projeto executivo da Favela Baixa do Caranguejo.

\subsection{O projeto como processo de aprendizagem}

\subsubsection{O olhar de dentro da cidade}

As experiências anteriores serviram para levantar a observação de que os interesses das comunidades em que trabalhei não eram integralmente percebidos e/ou atendido pelos critérios técnicos. A suposição era a de que o conhecimento e o envolvimento da população na decisão ou mesmo na apresentação de um projeto que intenta a mudança no seu habitat deve ser parte inseparável do mesmo. Isso poderá garantir o maior alcance dos recursos investidos, seja pela qualidade dessas mudanças, seja pela divisão das responsabilidades, pelo entendimento por parte de quem recebe os investimentos, além do uso adequado e da manutenção dos novos equipamentos.

No estudo de caso desta pesquisa, os dados secundários obtidos no concurso eram insuficientes para a realização do projeto. Precisaríamos visitar a área, e rastrear outras fontes com informações mais precisas. Para o conhecimento da área, utilizamos as referências da escala humana, e para isso, iniciamos uma caminhada até o lugar. Como localização geral, tínhamos um ponto qualquer situado ao longo da Avenida Suburbana, menos conhecida como a Avenida Afrânio Peixoto. Tomamos um ônibus na direção dos Alagados, descendo no início da avenida suburbana, o que nos causou algumas horas de caminhada em uma avenida altamente caótica, visual e sonoramente, e de uma fetidez quase insuportável, da mistura do cheiro de óleo de carro queimado, comida e esgoto a céu aberto.

Nessa longa caminhada, andamos pelas redondezas, apurando como e com que o "reconhecimento" se dava pelos praticantes do entorno. Até onde o Caranguejo se inseria no bairro? Como era acolhido por seus vizinhos?

Percebemos que tudo parecia uma profusão caótica de informações, coisas, cheiros e sons incompreensíveis, que não era apreendida no primeiro contato. Realizamos outras observações, e aos poucos fomos desmontando um castelo de preconceitos que havia se instalado não sabemos como, quando e onde.

Descobrimos o local exato onde o Caranguejo se situava através de uma moradora. Até ali, moradores de outra região no entorno não sabiam onde era o Caranguejo. 
O trecho da Baixa do Caranguejo, em relação à avenida, depois do extenso paredão de construções precárias, era abaixo do nível da avenida e estava livre, despontando uma paisagem para a pequena enseada dos Tanheiros, situada na Baía de Todos os Santos. Ainda observávamos a Ponta de Itapagipe, com a Igreja do Bonfim na parte alta da colina e sua cúpula dourada; ao fundo, as muitas embarcações e veleiros.

Os três acessos à área de intervenção apresentavam naturalmente uma hierarquia, no sentido de importância para seus moradores, resguardadas suas devidas proporções. Existiam duas ruas mais largas com passagem para carros, depois outros caminhos que iam se estreitando até os lugares onde moravam as pessoas com menos recursos, até se transformarem em becos muito estreitos, de sessenta centímetros de largura.

Da Avenida Afrânio Peixoto cota 10, ao Caranguejo cota 1, de carro, tem-se uma rua ao norte, chamada Estrada de Lobato, e ao sul, Campinas de Lobato; a seguir, no sentido norte/sul, Travessa Elisângela, Rua Senhor do Bonfim, com cinco metros de largura e traçado geométrico irregular, reforçado pelo posteamento colocado aleatoriamente. A seguir, a Rua do Pontilhão, com quase três metros de largura e um canal de esgoto a céu aberto, que recebe toda a água da Avenida Afrânio Peixoto e adjacências, para seguir com acesso por escadaria drenante à Avenida São José e a alguns becos sem nome.

As ruas mais largas, ao todo, eram cinco ${ }^{18}$ : Afrânio Peixoto de Baixo, Senhor do Bonfim, Voluntários da Pátria, Rua do Pontilhão, Estrada de Lobato; formavam uma trama irregular e se ligavam através de estreitos e irregulares becos, muitas vezes sem saída. No trecho mais pobre, a passagem que levava aos casebres minúsculos de um único cômodo era feita de tábuas reutilizadas, de talvez uns trinta centímetros de largura, frágil, balançava ao sopro de qualquer brisa.

O desnível entre a avenida e o Caranguejo era de dez metros; a descida perigosa para crianças e idosos e, na época de chuvas, dava-se o assoreamento das encostas, obstruindo a entrada das casas. A descida por essa escadaria, esculpida no barro pelos próprios moradores, dava o acesso aos caminhantes e chegava à Avenida Senhor do Bonfim, a rua mais larga da Baixa do Caranguejo.

Nosso intento, nessa primeira visita, era nos apresentar ao líder da comunidade, identificado pela instituição pública como senhor Marivaldo. Por essa razão, continuamos nossa jornada, por uma ruela reduzida, chamada 25 de Maio que, pela irregularidade, não nos

\footnotetext{
${ }^{18}$ Ver desenho esquemático do morador.
} 
deixava ver os primeiros três metros à frente. A residência do representante localizava-se em uma viela comprimida em razão das famosas “puxadinhas” que nunca acabavam; outros becos foram surgindo, ainda mais estreitos, à medida que chegávamos ao miolo da favela.

Naquela mesma visita, o sr. Marivaldo nos levou a dar um longo passeio em todo o bairro, ruas, becos, avenidas de cômodos de aluguel conjugados com um único banheiro do lado de fora. Durante o percurso, ouvimos algumas histórias contadas pelos moradores mais antigos, enquanto captávamos os cheiros, as cores, os rituais, os sons. As casas eram coladas parede a parede, com exígua possibilidade de abertura de espaços livres, em cujo interior escuro e úmido sempre conservavam um espaço para o cultivo de plantas e ervas medicinais.

Completamos as informações com outras pesquisas, artigos de jornal, fotos antigas, histórias de moradores, para averiguarmos em detalhes em que contexto aquele pedaço da cidade se inseria na história de Salvador. Quais as histórias daquela área integradas à história da cidade? Com que conhecimentos deveriam alimentar o projeto, para que esse fosse capaz de propor um desenho contendo a mesma riqueza, respeitando a diversidade e a especificidade do lugar, considerando os pontos de encontro consagrados pela comunidade?

Como equipe multidisciplinar, os outros profissionais fundamentaram suas informações também com visitas ao local, conversando com moradores. No desfecho, realizamos um encontro entre a equipe e os moradores, apresentando a equipe e a que veio, para, a seguir, identificar as questões importantes, priorizar os problemas, encontrar e definir as soluções para os problemas priorizados. Essa reunião aconteceu antes do resultado do concurso.

O resultado, nossa equipe fora selecionada, permitiu que realizássemos mais trinta e três encontros, ocorridos uma vez por semana ou a cada quinze dias, dependendo da ponderação entre a demanda dos moradores em discutir o projeto e da solicitação da instituição pública ao executivo. A meta da equipe era analisar e avaliar as propostas apresentadas no concurso, e fortalecer o processo participativo, ao mesmo tempo em que amadurecia o conhecimento e as ferramentas do planejamento, desenvolvimento e execução do design (arquitetura).

Consideramos de grande importância o fato de que o processo e o projeto tivessem tido tempos diferenciados. O primeiro, o tempo do projeto - entrega do projeto - era o tempo político da instituição, descolado da questão maior, a integração dos moradores da área à cidade, estabelecida na própria efetivação da resolução e que corroborava o financiamento 
para os investimentos. O outro, era o tempo de os moradores da comunidade levantarem e discutirem suas próprias questões, ao modo deles, entre eles, definir suas prioridades, abrindo espaço de discussão e tomadas de decisão fundamentadas em seu cotidiano, que só eles conheciam.

Nosso desafio maior como técnico, no papel de conduzir o surgimento de tais questões, era o de aproximar ao máximo essa diferença, para que a comunidade percebesse que o projeto continha as expectativas dela. Ao reconhecer esses pontos de fragilidade e, ao mesmo tempo, enfatizar muito mais o potencial latente para mudanças de mentalidade na comunidade, poder-se-ia tomar conhecimento dos novos usos e nomear a responsabilidade de participação de cada um.

Os temas eram diversificados e propostos pelos participantes. A demora para a assinatura do contrato impediu que a equipe contratasse os serviços complementares, tais como topografia, sondagem, aplicação de questionário sócio-econômico; além do mais, deixava a comunidade desconfiada, se de fato as obras iriam acontecer. Nesses encontros, avaliamos e realimentamos o projeto inicial apresentado ao concurso, amadurecemos o comprometimento com as mudanças, ampliamos a comunicação e melhoramos o entendimento entre os técnicos e os moradores. Após quatro meses de espera, veio a assinatura do contrato; o prazo para entrega do projeto era de trinta dias, o que causou um tumulto entre os coordenadores das equipes. Contornou-se a situação entregando um projeto incompleto, para que, enquanto estivesse sendo analisado, tivéssemos tempo de terminar o projeto completo.

Um dos aspectos metodológicos que ajudaram na troca dos saberes foi o programa chamado Mapinfow do SIG - Sistema Informativo Geográfico, que utilizamos para produção de mapas temáticos. Na base cartográfica da área, eram demarcadas e identificadas as poligonais que correspondiam às unidades habitacionais, relacionando todo polígono a um conjunto de dados adquiridos através de um questionário censitário aplicado uma a uma residência. Tal banco de dados possibilitava a construção de mapas temáticos: tempo moradia; certificado de propriedade; unidades com banheiro completo e outras informações. Em toda reunião, o mapa, em escala $1 / 250$, com as poligonais representando, era fixado com fita adesiva sobre o chão, fazendo com que os moradores encontrassem mais facilmente sua habitação. Dessa forma, além de o participante do encontro marcar sua presença pintando sua casinha no mapa, tinha o contato com as ferramentas do design e, para a equipe técnica, demonstrava como estavam sendo distribuídos a presença dos moradores na região. Para 
outros encontros, os moradores mais antigos levavam fotografias ou jornais antigos, desenhos, e relatórios escritos por eles.

No grande mapa georeferenciado, as pessoas iam pouco a pouco descobrindo como trabalhar com aquele instrumento, percorrendo ruas, identificando a localização de suas casas, dos conhecidos, o comércio. Os que aprendiam com mais desenvoltura auxiliavam os que tinham dificuldade na utilização do mapa, a equipe técnica ficava observando de fora, acompanhando as explicações entre os vizinhos, ampliando o conhecimento com outros moradores em outras áreas, fortalecendo a corrente de vizinhança. Outras vezes, moradores mais antigos descreviam a paisagem antiga e a sua colaboração na transformação dessa mesma paisagem. Houve algumas tentativas para que acontecessem reuniões por vizinhança, para que pudessem tomar suas próprias iniciativas, mas não aconteceram. Para isso, distribuímos cópias de pequenos trechos da área por vizinhança, entretanto eles não conseguiam promover a reunião.

Em todo o processo, realizamos a leitura do bairro, identificamos questões a serem resolvidas, definimos prioridades e encontramos soluções para incorporar no projeto. Durante a obra, isso foi significativo na fiscalização quanto às adequações e mudanças de projeto, que algumas vezes visavam a reduzir custos e facilitar o trabalho da empreiteira, sem considerar a qualidade do projeto apresentado pelo arquiteto e entendido pelos moradores.

Alguns desses encontros eram utilizados para a apresentação da revisão e do resumo dos principais pontos apresentados em reuniões anteriores; esses, em sua maioria, eram realizados pelos próprios moradores. O objetivo, entre outros, nesses encontros, era o de ressaltar os elementos de ligação entre as conclusões e ao que atenderiam tais elementos, de maneira clara e simplificada, para que todos entendessem.

\subsubsection{Relatos do cotidiano.}

Para que se entenda a dimensão pedagógica do processo participativo do estudo de caso, necessária se faz a apresentação do escopo básico contido no contrato licitante. A finalidade de desenvolver um Projeto Executivo de Urbanização e Infra-estrutura de áreas de Sub-Habitação compreendia desenhos do sistema viário com arruamento, caminhos e acessos; a identificação e projeto de tratamento em caso de áreas de risco, implantação das unidades habitacionais a serem construídas e/ou recuperadas com a definição dos serviços necessários; sistema de abastecimento de água e seus respectivos projetos; colocação dos equipamentos 


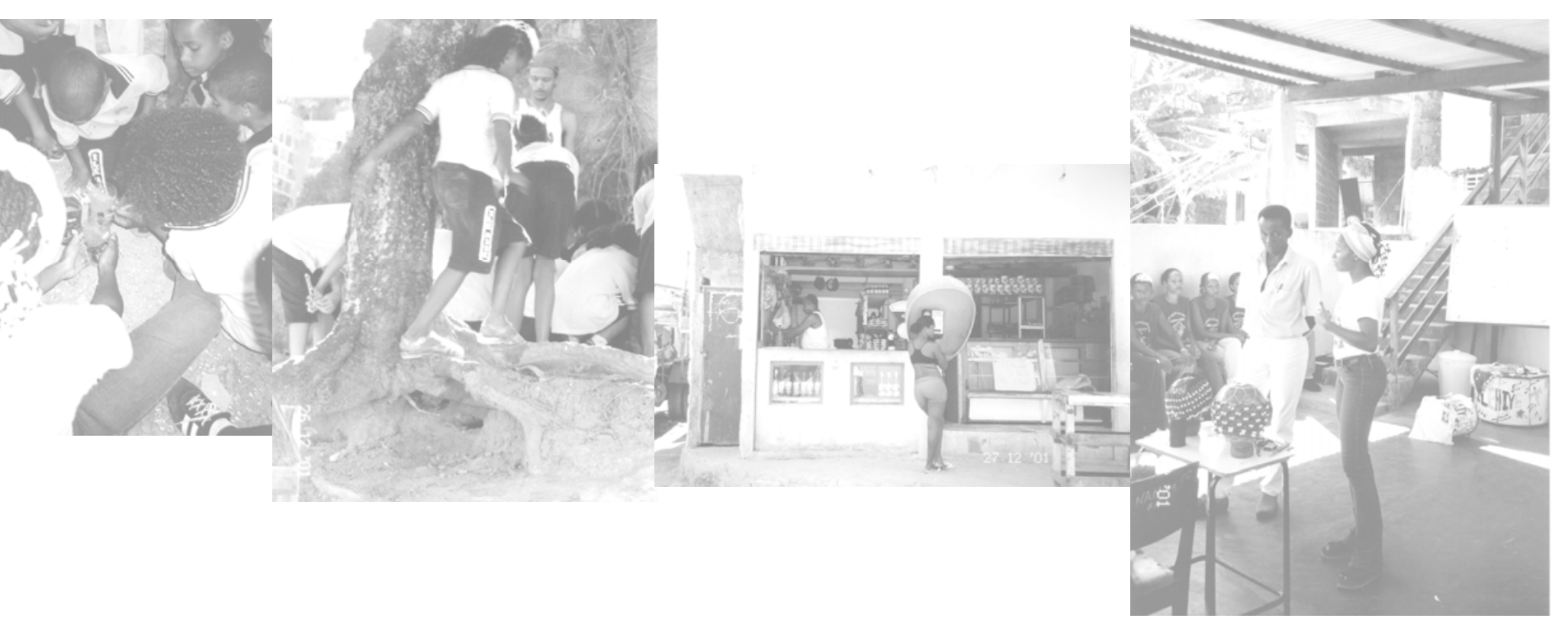

Antes de iniciarmos as discussões, cada profissional se apresentou, falando de sua função no projeto. A seguir, explicamos o que estava para acontecer, falando do concurso, o que era, e qual o objetivo a ser alcançado quando do seu resultado. Explicou-se o que significava reurbanizar o bairro, as mudanças que provavelmente aconteceriam, perguntando o entendimento sobre nosso vocabulário e ouvindo, na explicação de alguns, quais palavras utilizavam para se explicar. Que desdobramentos no espaço coletivo do bairro teriam? Na fase inicial, como seriam representados? Qual a ligação com os desenhos nos painéis para julgamento e escolha do projeto mais adequados à realidade da área? Respondendo a tais questões, estaríamos reforçando a importância e o sentido de estarmos juntos, aprendendo a mitigar os conflitos e a construir consensos do espaço coletivo, trocando informações, colhendo dados, aproveitando o conhecimento que cada um dos presentes detinha em sua área específica.

Da discussão sobre os pontos positivos e outros que precisariam melhorar no bairro, a maior parte das pessoas presentes concordou que a situação mais inconveniente era quando chovia, pois a água que vinha de todos os lugares, e não apenas do bairro, arrastava com força o que tinha pelo caminho, inundando rapidamente o interior das casas, com lixo e tudo mais que encontrava no percurso. Segundo moradores da Rua Quatro de Julho e do Pontilhão, eles eram o mais atingidos, e como nessa mesma via já existia uma calha aberta de esgoto misturado às nascentes da área, formava-se uma lâmina d’água que nunca ficava seca. As crianças eram as primeiras vítimas, brincando dentro da vala, o que provocava uma série de doenças. Para a solução do problema, um morador sugeriu que a caneleta de coleta fosse aumentada na Rua Pontilhão e na Rua Elisângela. Um engenheiro sanitarista ficou de calcular 


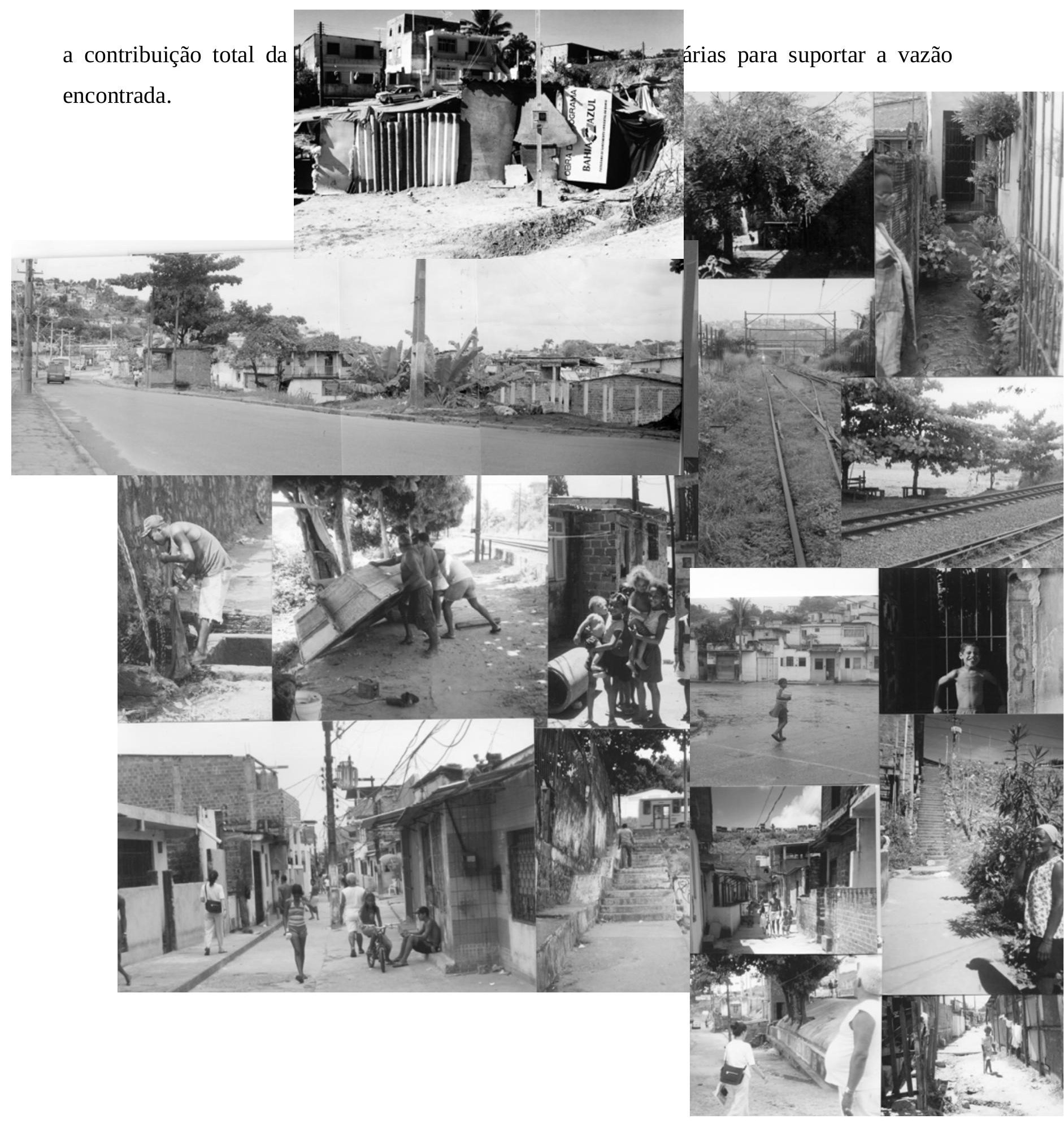

Um outro residente da Rua Elisângela apontou a terraplanagem, entendida por ele como aterro, para aumentar os níveis das casas, achando que com a elevação do nível da rua as águas não correriam para o bairro. Os próprios moradores descartaram a idéia quando em toda a extensão do Caranguejo, equivalente aos 12,64ha. Outra resposta veio do grupo de mulheres, afirmando que precisariam elevar o telhado e as paredes, repassando o custo para os proprietários; isso era uma prática comum que causava muito transtorno para os habitantes da 
casa, eles já estavam cansados de tanto fazê-lo. Mesmo assim, decidiu-se que pressionariam a URBIS para que ela se responsabilizasse por esses custos, inclusive ajudando com mão-deobra.

Por outro lado, havia a falta de encanamento para receber a água limpa que não vinha todos os dias e, além disso, era poluída, pois toda a tubulação passava por entre esgoto a céu aberto. Os domiciliados da Rua Senhor do Bonfim entenderam que antecedia a esse problema providenciar o encanamento do esgoto a céu aberto, presente em todas as vias do bairro, distribuindo sujeira, mau cheiro, atraindo ratos, moscas e outros bichos, antes de aumentar a contribuição de mais água. Outro morador mais antigo lembrou da época em que o governador Waldir Pires apareceu por lá com alguns políticos, acompanhados de meia dúzia de trabalhadores para resolver o problema do esgoto, garantindo ajuda financeira com o reforço da mão-de-obra dos próprios habitantes. Marcamos uma visita ao local para documentar os restos dessa iniciativa que não obteve resultados satisfatórios; a reclamação maior foi a de que moradores roubavam os materiais e os políticos desistiram de concluir as obras.

A pavimentação foi o terceiro ponto colocado: a estreiteza dos becos e das ruas não deixava passar nem um carrinho de mão carregando um botijão de gás, quanto mais uma ambulância. Chamaram a atenção para alguns mais poderosos, que não paravam de construir as "puxadinhas”, como sendo os principais responsáveis por essas ruas estreitas; só o governo tinha força para desmanchá-las. Concluíram que eram muitas e para não inviabilizar a obra, principalmente na disponibilidade de recursos, apontaram como prioridade as das ruas Pontilhão, Afrânio Peixoto de Baixo, Senhor do Bonfim, General Coelho, Quatro de Julho, e Nossa Senhora das Candeias.

A equipe técnica, em outros encontros, utilizando a ferramenta do SIG — Sistema Informativo Geográfico — , através do programa MAPINFO, e da aplicação de questionários, pôde identificar todas as casas feitas em madeira ou outro material precário, que poderiam desobstruir tais passagens. Discutido o assunto com os participantes, alguns ficaram encarregados de persuadir os donos desses barracos a deslocá-lo, para outro local, construindo-o já em alvenaria, possibilitando a desobstrução da passagem. Descobriu-se que durante as obras, a construtora, por falta de planejamento, não cumpriu tal meta, construindo no mesmo espaço em que havia o barraco de madeira, uma unidade habitacional em alvenaria, permanecendo o estreitamento da via conforme tínhamos apontado como espaço a melhorar. 
A quarta situação encaminhada foi a da violência; a denúncia vinha das meninas, na idade entre 13 e 18 anos. Apontaram como principal causa os pontos sem iluminação dos postes, que dificultavam a passagem, mesmo nas primeiras horas da noite. A maioria das garotas com mais idade precisavam estudar à noite porque ajudavam nas tarefas de casa. A equipe técnica foi dialogar com a gerência da linha férrea: mostrou-se a inviabilidade de trocar as placas de concreto que constituíam o paredão em volta dos trilhos por algo transparente; para os moradores, a idéia melhor era colocar policiais de ronda.

Para outras questões não seria urgente encontrar soluções, pois a importância era planejá-las e pressionar o poder público com propostas, para resolvê-las num futuro próximo. Exemplo disso, seria a instalação de um Posto de Saúde bem perto. Na ocasião, o mais próximo da região ficava em Itacaranha e Calçada; a viagem de ônibus onerava a

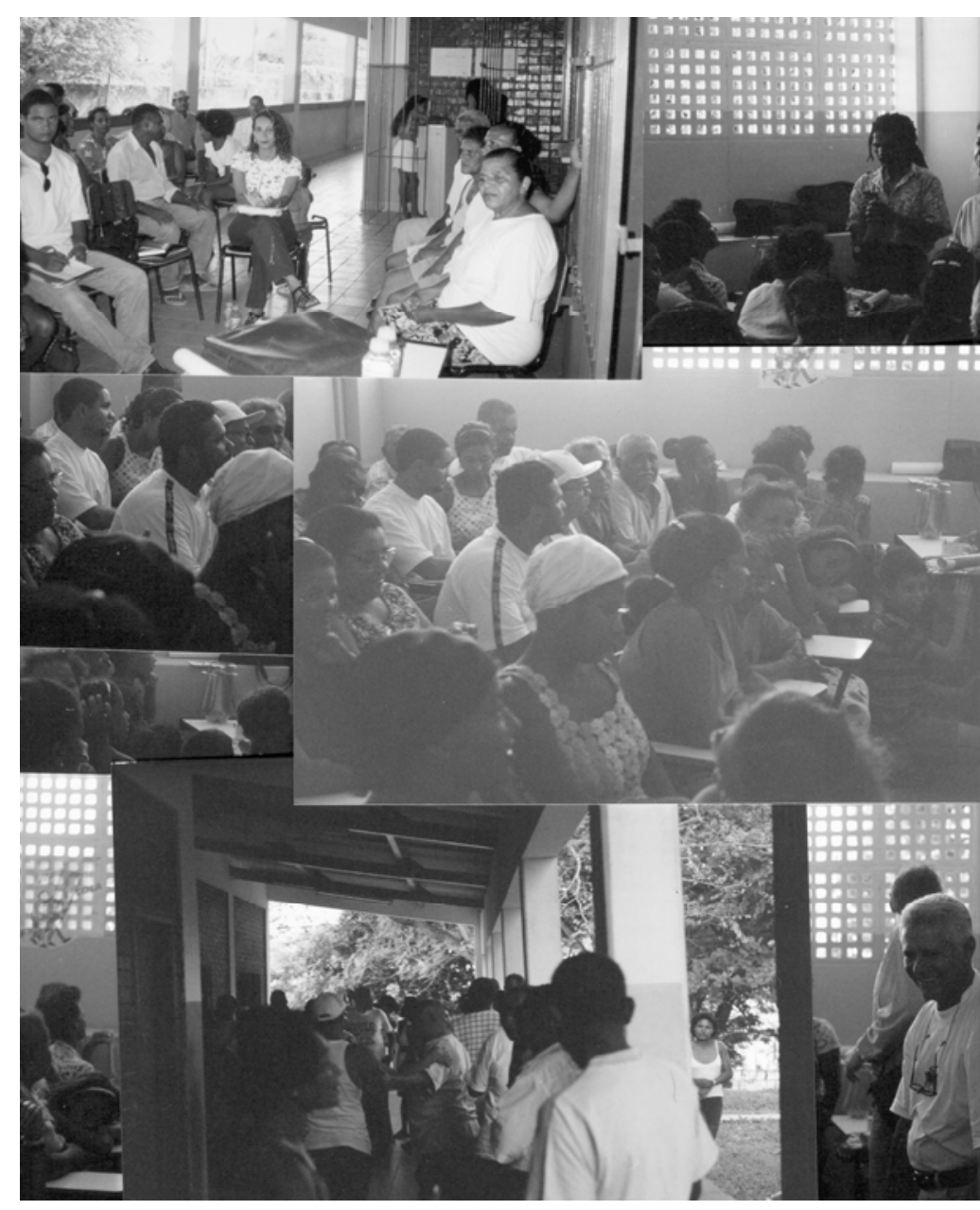
renda familiar, que já era pouca. Um outro equipamento sugerido pelos moradores seria um centro comunitário, em que pudesse funcionar uma creche. Essa foi uma necessidade apontada pelas mães que trabalhavam fora e não tinham onde deixar as crianças, pois as que existiam no bairro não ofereciam vaga. Outras escolas de ensino fundamental eram: Tenente Almir, Climério de Oliveira, Eufrosina Miranda, Ailton Pinto de Andrade até o Ginásio Dalva Matos; no básico, Raimundo Matos, São Roque Santa Luzia de Lobato e Tereza Mata Pires. $\mathrm{Na}$ opinião dos moradores, havia escolas até em demasia, o que elas precisavam era equacionar a falta de professores e outras deficiências de materiais, como carteiras, armários, giz, juntamente com as condições adequadas nas salas de aula.

A passarela por cima da linha de trem servia para fazer a travessia do Largo do Lobato até o lado da praia; na ocasião sua instalação era precária, poucas pessoas a utilizavam devido 
aos acontecimentos do passado, uma chacina em que seis jovens morreram em brigas e tiroteios.

O aspecto positivo do bairro era a condição que os moradores tinham de não pagar aluguel, a casa era própria e perto de quase tudo. Além disso, a vizinhança era unida, principalmente nas horas críticas, porque quando havia alagamentos e enchentes, eles se juntavam e resolviam com rapidez tudo que precisava ser resolvido. Comentaram em tom de denúncia que a associação estava inativa há pelo menos dez anos; desde o governo Collor, não aconteciam as reuniões e eles sentiam falta delas.

O grupo de jovens entre 12 e 19 anos destacou que o banho de mar era momento de lazer e diversão durante e nos finais de semana; entretanto, percebiam que o mar estava poluído e mal cheiroso, pediam uma limpeza nas praias. Reclamaram falta de pontos “legais” de encontro, os poucos que existiam eram ruins, quebrados, pouco iluminados e,

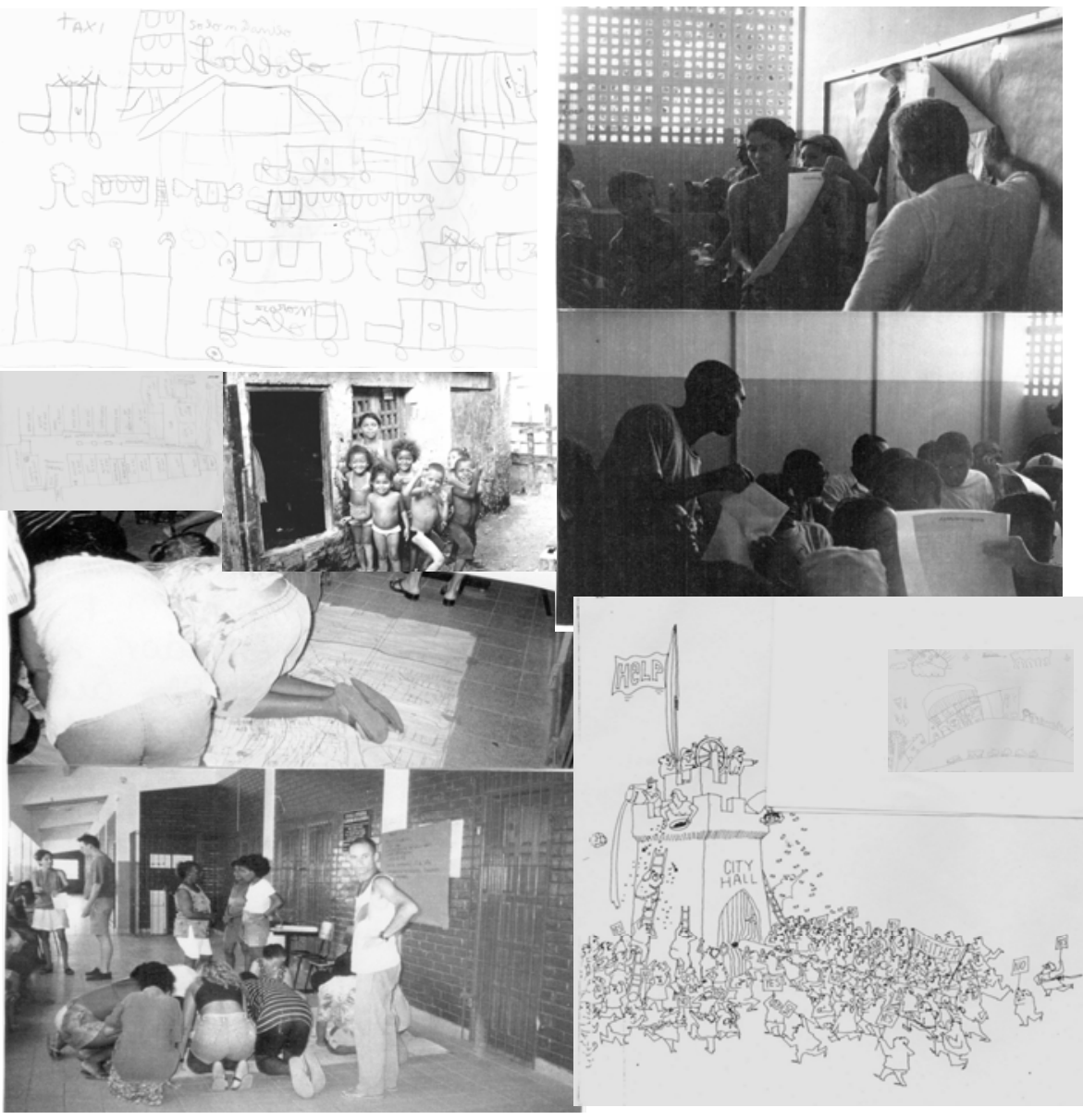
por isso mesmo, perigosos de freqüentar: a prainha, a pracinha da passarela, e a praça do reggae depois da Cesta do Povo. Gostariam de desenvolver alguma habilidade para ajudar no orçamento doméstico; sugeriram ocupar alguns espaços, já existentes, para cursos profissionalizantes, como a Escola Climério de Oliveira, a oficina de Seu Geraldo e a marcenaria de Seu Esmeraldo. Por essa razão foi que, em outros encontros, realizamos oficinas de reciclados com o Pelé do Tonel.

Com a confirmação do resultado em favor de nossa equipe, marcamos a terceira reunião, dando continuidade ao tema da primeira, revisando o que fora discutido com os desenhos apresentados no concurso. Com o material produzido naquela reunião de maio, e os 
dados técnicos de cada membro da equipe, sistematizados em seis painéis, apresentamo-los aos moradores.

Os encontros se sucederam a cada duas ou três semanas, avaliando o processo inicial. Utilizamos duas vertentes: na primeira, uma avaliação do que fora proposto anteriormente, e sua compreensão com mais detalhes, acrescentando ou retirando itens do projeto de urbanização a ser aplicado na área, examinando sua representação nos desenhos como os mapas, as fotografias aéreas, os croquis e perspectivas. Na outra, dando continuidade à identificação, priorização de questões levantadas inicialmente, implícito estava, nessas ocasiões a importância de mantermos tais discussões coletivamente. Enriquecemos com essa fase o projeto executivo, que foi entregue à instituição pública a seguir.

As reuniões seguintes, que no mês de julho ocorreram semanalmente, foram realizadas no pátio coberto da Escola Climério de Oliveira, dentro do terreno da empresa Joanes Leste, uma fábrica de beneficiamento de óleo de mamona. Uma média de oitenta e cinco a cem pessoas esteve presente, sem contar as crianças entre cinco e dez anos, acompanhando os pais, e que se expressaram através de desenhos. Explicamos as próximas etapas para aprovação e execução do projeto.

No período de quatro meses que a instituição pública levou para avaliar o projeto entregue, a equipe técnica e a comunidade aproveitaram para continuar o amadurecimento e a ampliação de uma coesão entre os presentes: apreender o conhecimento partilhado, desenvolver um controle coletivo melhor em relação a informações técnicas, para criar melhor possibilidade de diálogo entre a construtora e a instituição, imprescindível para adequar o projeto no momento da execução na obra.

Outro ponto que considerávamos primordial, principalmente para o acompanhamento das obras, e não conseguimos aplicar, foi a instalação de um escritório técnico permanente no bairro. Procuramos um espaço para alugar e encontramos, na Rua Senhor do Bonfim, uma sala com aluguel de R $\$ 100,00$. O contrato não cobria tais gastos e por esta razão não pudemos desenvolver, com mais intensidade, os trabalhos de compreensão do projeto com a comunidade. Outros investimentos já haviam sido feitos, tanto para o grupo técnico como para os moradores conhecerem com mais particularidades aspectos qualitativos e quantitativos da comunidade, como a aquisição do software do programa de georeferenciamento que serviu de base, e os honorários do especialista. 
Como forma de dar continuidade à qualidade do projeto durante a realização das obras, foram propostas parcerias com a ONG CDM / Associazione Voluntari per il Servizio Internazionale - AVSI e com a Caixa Econômica Federal, principalmente nos nossos trabalhos de adequação do projeto executivo à execução da obra. A instituição pública URBIS/CONDER foi a responsável oficial pelo projeto social, recebendo para tal e, enquanto aguardávamos o tempo definido nesse projeto de atuar com a comunidade, nossos trabalhos continuaram empenhados em melhores condições, não apenas nas atividades, mas em documentar como estava ocorrendo a participação dos moradores. Não foi possível instalar nosso escritório no Caranguejo, assim como acompanhar a adequação das obras, uma vez que fomos convidados a nos retirar quando do início da obra e do projeto social.

Os seis painéis do concurso foram expostos em todas as nossas discussões. Conversamos sobre as idéias passadas e as futuras, identificando como e onde essas idéias estavam representadas naquelas pranchas, confirmamos o entendimento delas e se precisávamos acrescentar outras informações. Verificou-se que nem todas as idéias estavam contidas no desenho, pelos limites dos recursos, mas poderíamos recuperá-las caso achássemos ser importante. Dividimos com os participantes a autoria e o sucesso de nosso projeto ter sido escolhido.

Nesses encontros sempre destacávamos a importância de estarmos juntos aprendendo uns com os outros. Com o firme propósito de ampliar a autonomia da comunidade, a equipe técnica fez uma outra tentativa de promover as reuniões por vizinhança; dessa vez o arquiteto/pesquisador passaria como observador por cada uma delas.
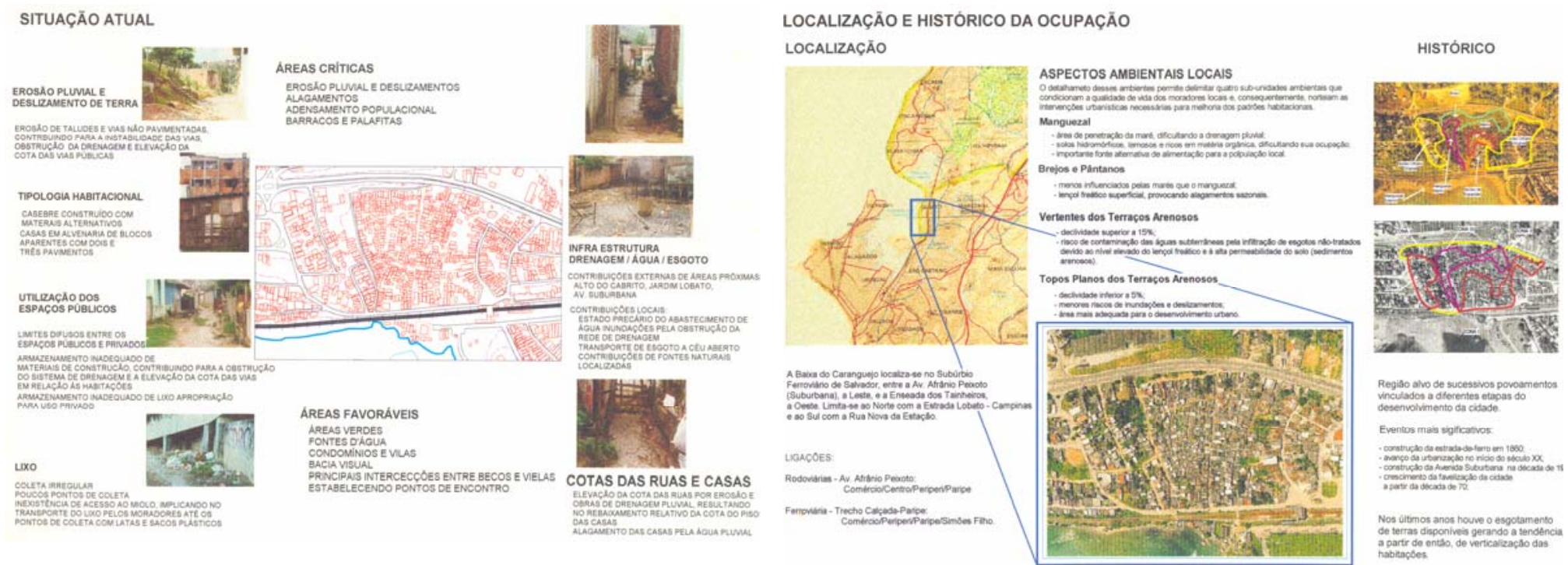
Naquela ocasião, foram apenas três iniciativas, uma na Rua Voluntários da Pátria com o grupo de jovens; outra na Travessa Senhor do Bonfim, e a terceira na Rua General Coelho. O resultado não foi positivo, mostrando que a iniciativa por parte dos moradores, sem o incentivo do arquiteto/pesquisador estava longe de acontecer.

Nos encontros do mês de agosto, resgatamos o histórico de organização da associação da comunidade, explicamos o início do cadastro, e a aplicação do questionário, em que optamos por contratar os próprios moradores. Pelas informações obtidas entre eles, podemos afirmar que o quadro era de extrema fragilidade no processo organizativo.

Aquela comunidade fez de seu dia-a-dia foco de ação de intermediários externos, submetendo-se a um complexo de favores assistencialistas, acreditando estar lutando e conquistando obras públicas, quando conseguia apenas alguns parcos benefícios.

A associação de moradores a que eles se referiam como associação de fulano, de seu beltrano era mero artifício de ordem político-partidária, manipulada por interesses muitos específicos. Por exemplo, em 1987 foi criada, por um vereador, uma associação no bairro. Começaram nessa época obras de construção de esgoto, que apenas foram realizadas em uma parte do bairro, coincidentemente em ruas de moradores que faziam parte da diretoria da associação. Segundo pessoas entrevistadas, uma das causas pelas quais essas obras não foram concluídas foi o roubo de material que era depositado nas ruas do bairro. Segundo relatos, os próprios moradores roubavam tijolo, cimento e areia, para benefício particular. Outros moradores alegam que essa associação se manteve enquanto existia o tíquete de leite, cesta básica e distribuição de verduras doadas pela antiga empresa Paes Mendonça. Naquela ocasião, a entidade cobrava $\mathrm{R} \$ 1,00$ de mensalidade, mas a maioria se desligou, alegando que o presidente ficava com o dinheiro.

A partir de 1994, o governo terminou com a distribuição do tíquete de leite; no caso da cesta básica, o presidente da associação deveria fazer parte da Comissão de Saúde, para isso comparecendo todas as sextas-feiras à reunião. Como a pessoa trabalhava naquele horário, perderam o direito de obter a cesta. Quanto à distribuição das verduras, era preciso o agenciamento do transporte para ir ao local buscar; por falta de recursos para o pagamento do frete, também perderam essa regalia.

Alguns anos mais tarde a associação foi novamente retomada pelo antigo presidente e um grupo de moradores; a legalização formal foi outro problema enfrentado por eles, pois era preciso dinheiro para os registros da atualização dos dados no setor jurídico. Essa realidade 
precipitou a desestruturação organizativa que existia na comunidade, que tinha dificuldade de enxergar que era fundamental a complementação e a solidariedade, fora dos momentos de apuro, para articular o campo político, construir o poder local e fortalecer sua identidade.

Nesse sentido, o processo de elaboração do projeto através dos encontros vem a fortalecer a participação e a organização comunitária. Os moradores trouxeram sugestões, fotografias, desenhos, relatórios e recortes de jornais, aumentando o interesse pela própria intervenção.

Em setembro, nosso tema principal foi o lixo. Realizamos uma série de oficinas com um convidado de fora, um capoeirista que trabalhava na empresa de resíduos sólidos de Salvador. Iniciamos a reunião relembrando o que tinha ocorrido no último encontro e o que tinha ocorrido entre os intervalos. O tema do lixo despertou o interesse de todos, que apresentaram problemas que tinham relação com seu dia-a-dia; essas informações foram sistematizadas em painéis de papel craft, com as respectivas soluções.

Discorremos sobre o marco histórico da área, que foi a descoberta de petróleo, associando ao nome do bairro uma homenagem a Monteiro Lobato: uma foto com a torre e Monteiro Lobato próximo a ela foi encontrada por uma dos moradores. Discutimos o processo de cadastramento que já estava sendo realizado, alguns agentes fizeram a queixa de que moradores estavam se negando a responder ao questionário.

As oficinas foram produtivas principalmente para as crianças, que saíram com brinquedos coloridos, o encontro da arte com a natureza.

No mês de novembro, continuamos com a temática do lixo e a revisão do partido urbano adotado. Na segunda reunião do mês, a assistente social da URBIS esteve presente, assim como muitos moradores do lado do mar, das palafitas, que até então não tinham comparecido em número significativo. Verificamos que o discurso da assistente eram impreciso, especialmente em relação ao financiamento, que desde o início não era responsabilidade da nossa equipe, segundo o parecer dos técnicos da URBIS. As pessoas demonstravam preocupação: quanto tempo levaria e de quanto seria o financiamento para eles.

Em dezembro houve uma única reunião, com a engenheira sanitarista, e o enfoque foi sobre as inundações. No largo ao lado de uma casa CIPS - Cadastro de Identificação do Projeto Social - 501, 502, 503, 507, 508 e 509, o nível da rua representava sério risco de alagamento e influência das marés, principalmente nos períodos da maré de março e chuvas 
intensas. A solução simplificada dada pelos moradores foi a de elevar o nível das casas, mudança de cobertura, ou possível relocamento interno, constituindo assim, espaços livres para formação de piscina até escoamento normal. Os moradores do lado da prainha finalmente aceitaram o remanejamento para o interior do bairro. No espaço deixado pelas casas, projetamos uma praça com mirantes, com palco de apresentação sugerido pelo grupo de dança e apreciação do visual para a Baía de Todos os Santos.

Quanto aos relocamentos, foram previstos a partir de discussões com os moradores, para as áreas livres da Rua Senhor do Bonfim e Rua 4 de Julho. Ainda se falou sobre o lixo, e no mapa marcamos os possíveis pontos estratégicos de localização de contêiner: Rua General Coelho, Voluntários da Pátria, final da Rua Pontilhão, Rua Nova da Estação. Reforçamos e detalhamos melhor a utilização da passarela da linha férrea para prestação de serviços, tais como postos do correio, serviço de atendimento ao consumidos para obtenção de documentos, como registro geral de identidade, carteira de trabalho, certidão de nascimento.

No que se refere ao posto de saúde, a comunidade deveria sugerir para a reunião subseqüente que fosse na Voluntários da Pátria ou no Largo de Lobato. Marcou-se a reunião para o ano seguinte, no dia 10 de janeiro, e até lá a comunidade já deveria saber qual seria a construtora a ganhar a licitação para executar o projeto.

Retomamos os encontros em janeiro, utilizando a mesma estratégia de colocar o mapa no chão. Realizamos uma exposição com fotografias e relatórios que os moradores confeccionaram, oferecendo explicações, além de recortes de jornais resgatados pelo grupo de jovens. Nesse momento, o arquiteto/pesquisador já não fazia parte das discussões com os moradores, apesar de estar presente. Os participantes mais antigos de encontros anteriores se capacitaram a orientadores, antecipavam-se para explicar as dúvidas dos que chegavam tardiamente ao encontro ou aqueles que chegavam pela primeira vez.

Em março, tivemos outra reunião, com a presença do arquiteto diretor de planejamento. Um grupo de assistentes sociais da URBIS, depois da mobilização e da ida da população à URBIS, cobrou uma posição clara do presidente, para que ele apresentasse os motivos da demora para iniciar as obras. Como todo início de reunião, os que chegam pintam no mapa a sua casa. Essa reunião foi esperada com muita ansiedade pela comunidade, pois o espírito de descrença, desconfiança de que não iria acontecer a intervenção estava contaminando a todos. Então alteramos o roteiro previsto para a reunião, e passamos a palavra para o representante da URBIS, o arquiteto. Nesse momento, constatamos que a autoridade é histórica e não conquistada ou advinda do relacionamento com o trabalho no cotidiano. 
Algumas vezes surgia a pergunta dirigida ao arquiteto/pesquisador, quem representava e por que estava ali, já que não era do governo. Para eles ficou muito claro que só 'quem faz' são os políticos e o governo, demonstrando a dificuldade no processo de construção de objetivos comuns, coesão dos laços comunitários e conhecimento partilhado. Esse foi o momento de maior fragilidade do projeto como processo, a credibilidade do técnico sem representar nenhuma instituição pública. O arquiteto da URBIS falou sobre os objetivos do Programa Viver Melhor e que constam da resolução 181/95. No final, pediu paciência pela demora, em função dos desafios técnicos para resolver definitivamente os problemas do bairro.

Em novembro, ocorreu outra reunião em que só discutimos o sistema de drenagem e esgotamento sanitário.

A reunião de 19 de dezembro de 1998 definiu outros caminhos para o processo participativo da nossa equipe. Foi quando a URBIS entrou na área para iniciar as obras. Nessa reunião, anunciou que, a partir daquele momento, os responsáveis eram um outro técnico e uma assistente social representantes da URBIS que os trabalhos do arquiteto/pesquisador se encerrariam naquele momento. Eles apresentaram as diretrizes do programa, discorrendo sobre a cobrança dos benefícios; ainda estavam discutindo os valores das prestações. Informaram da instalação do escritório da URBIS no bairro, e de horários para atendimento. A associação precisaria se oficializar e discutiram outras informações técnicas mais individuais.

Na reunião do dia 13 de maio de 2000, houve exposição dos painéis, resgate da história do bairro, visões futuras, localização em relação à cidade, exposição de um grande painel contendo as fotos antes da obra, avaliação dos moradores na mudança desses cenários, breve relato dos encontros com a assistente social, e os nossos encontros; apenas dezoito pessoas estiveram presentes.

Durante uma semana, em novembro de 2004, tivemos reuniões em que o objetivo era discutir as observações e análises da intervenção após a conclusão da obra. Eles tomaram a iniciativa de tirar fotos, fazer desenhos e escrever relatórios descrevendo o resultado da obra, avaliada com críticas severas e acusando-a como mais uma gestão de descaso por parte da administração pública para com a comunidade. Foram realizadas algumas entrevistas que não serão sistematizadas neste trabalho. 


\subsection{Considerações preliminares}

Os pressupostos fundamentais que nortearam a aplicação da Resolução 181/95 e da Instrução Normativa 02/95 delinearam a concepção metodológica no estudo de caso, que foram sendo transcritas a cada encontro, entendendo que o diagnóstico partilhado não é uma seção estanque e, portanto, abarca informações essenciais para a estimativa de tendências. Na construção desse diagnóstico, a busca histórica do lugar ajudou a reconhecer o sistema de investimentos sociais, a estrutura e o funcionamento da comunidade, em que se incluiu a previsão do que provavelmente sucederia caso não se introduzissem as modificações identificadas à situação na época. Os problemas diversamente percebidos pelos distintos níveis das pessoas envolvidas foram convenientemente observados, identificados e compreendidos entre elas.

Para o desenho urbano, a integração à cidade naquilo que lhe pôde elevar o nível de existência valorizou e manteve as especificidades culturais que a caracterizavam. Consagraram-se os lugares de encontro, ampliando seu uso através da colocação de equipamento urbano como bancos, arborização, calçadas, guarda-corpo. Para dar à área uma situação de bairro, valorizamos o ponto, ao longo da avenida suburbana, onde ela surpreende com uma paisagem para a enseada, com a retirada das três casas existentes, substituídas por árvores, e o plantio específico de retenção da encosta íngreme entre a avenida e a rua paralela de baixo. A negociação entre os proprietários dessas casas ficou sob a responsabilidade de alguns voluntários moradores.

No equipamento instalado nos anos 80 - a passarela de travessia entre o largo de Lobato e a subestação no lado do mar —, em escala desproporcional à do bairro na parte superior, instalamos os postos de atendimento diversificados, e no espaço do largo de Lobato, ao ar livre, um grande espaço multiuso; no enorme paredão da passarela voltado para o largo, um telão para o cine popular e outras manifestações culturais. Ainda no processo de desenvolvimento do projeto, realizamos dois espetáculos organizados por um grupo de teatro alternativo.

Planejamos sob a ótica de desenvolvimento sustentável ${ }^{19}$, buscando discutir com os participantes: as dificuldades e os limites na relação entre o técnico, o poder público e a comunidade; a necessidade de adequação do projeto à construção; e o treinamento

\footnotetext{
${ }^{19}$ Sustentável: termo utilizado pela primeira vez no encontro de 1972, em Estocolmo, é a velocidade com que retiramos os recursos, em que quantidade, e a capacidade da natureza de absorver resíduos e repor os recursos. Traduzido em termos de intervenção num espaço físico significa mitigar os impactos entre a relação dos processos sócio-culturais e os processos naturais, o que não deixa de ser uma valoração subjetiva.
} 
imprescindível para a conquista de um lugar de discussão com a instituição pública e a empreiteira. Do ponto de vista financeiro e de trabalho incorporado, discutíamos a sua conservação na medida em que não estivesse comprometendo o coletivo ou a qualidade do ambiente.

A participação, como ponto central, teve na elaboração do projeto, na negociação de soluções, no acompanhamento da execução uma cumplicidade e parceria que foram reveladas com intensidade quando o arquiteto/pesquisador de fora do processo foi solicitado inúmeras vezes pela comunidade, que reconhecia alterações no que havíamos discutido e não estava sendo negociado, nem mesmo apresentado à comunidade. Não é objeto de análise nesta pesquisa. Nesta perspectiva, a parceria anteriormente estabelecida entre o arquiteto/pesquisador e a comunidade, as atitudes do poder público e da construtora quando do inicio das obras e do projeto social prejudicou a continuidade no processo de adoção por parte da comunidade das mudanças em seu habitat, reduzindo a capacidade de gerenciamento da mesma.

Assim, a fragilidade do processo organizativo da comunidade distorceu suas crenças de luta e conquista, quando de fato, em nome do combate à pobreza, constrói seu isolamento, conseguindo apenas migalhas e restos dos poucos benefícios que lhe são concedidos, e parcamente aplicados. Eles perceberam essas manobras por parte do poder público e construtora, entretanto, por conveniência ou mesmo falta de habilidade na força de mobilização e pressão, demonstraram estar sempre à mercê de promessas de pessoas que, por alguma razão, tomam deles em benefício próprio. A ilustração do que estamos afirmando foi relatada pelos próprios moradores. A diretora representante da instituição pública, na ocasião gerenciando os recursos do programa Viver Melhor, em uma estratégia de manipulação, conseguiu o cargo de deputada federal, e nunca mais voltou lá para ver que os quatro milhões de reais aplicados esvaíram-se pelas valas ainda a céu aberto dos esgotos na Favela Caranguejo.

Tal consideração talvez pudesse ser mitigada se o arquiteto/pesquisador, na condução do processo participativo, atento a essas fragilidades, enfatizasse claramente os objetivos e o método para alcance das metas estabelecidas.

As reuniões em alguns períodos demonstraram retrocesso, seja pelo tempo demorado em analisar os projetos e a insegurança que isso gerou em todos, seja ao se repetir demais os temas e assuntos, demonstrando que não estávamos evoluindo no processo organizativo, e em função também da herança histórica dos processos anteriores, uma vez que a instituição 
pública tinha uma mesma atitude, na demora e no silêncio, omitindo-se de dar satisfação do que estava acontecendo. Por outro lado, os encontros com toda a comunidade geravam ruído, o que tornava difícil o entendimento entre as pessoas. Por essa razão, realizamos algumas tentativas de pequenas e breves reuniões por vizinhança, embora estivéssemos o tempo todo instigando-os a tomar sua própria iniciativa.

A experiência mostrou a necessidade de se ter planos, políticas e investimentos financeiros bem formulados para comunidades populares, para que o desenvolvimento das ações adquira solidez e coerência, e essencialmente o planejamento traduza essas decisões em planos, projetos e em programas que conduzam as novas decisões. Também demonstrou que a legislação é uma gota no mar de interpretação da sociedade. Tanto na identificação de problemas como na construção do futuro desejado, o processo de idealização estará orientado por valores ideológicos, políticos e técnicos. Baseado nisso, a discussão se torna imprescindível, e a participação efetiva é vital.

A lógica do poder, precisamente a lógica dinâmica, funda a inevitabilidade da resistência e do desejo de mudança; do ponto de vista do desigual, a redução da desigualdade não é uma concessão dos governantes, mas uma conquista permanente e histórica, não como produto definitivo, mas processual. Por isso, a participação só pode ser conquistada. Aquela doada é “presente de grego”, porque vem do privilegiado, não do desigual. Assim, a redução da desigualdade que o desigual quer só pode ser aquela que ele mesmo constrói e aí está sua sabedoria.

A roupagem da participação ainda é uma farsa, distribui assistência, porque mesmo não resolvendo os problemas, pelo menos os compensa. Assim desmobiliza, distribui bens materiais ao invés do poder, usando o disfarce de conquista popular. O saber especializado é fonte de poder e pode estar a serviço dele, pela construção de uma linguagem ininteligível ao público, por planos ineficazes e ineficientes, pela retirada de informações de comunidades populares entregues ao poder; pela desconsideração da sabedoria popular.

Podemos desencadear o processo de aprendizagem, em que o conteúdo fundamental é a construção de instrumentações para o exercício da cidadania, pelos componentes do cotidiano, considerando e respeitando as identidades culturais comunitárias, através das quais se alimenta o processo de tomada de consciência crítica, condição prévia para alguém ser sujeito e não objeto. Onde os recursos que têm circulado estão sendo alocados para intervenções em assentamentos informais, é imprescindível que as críticas sejam apresentadas, questões sejam levantadas, discussões sejam praticadas, para que não se 
destruam anos de processos espontâneos de cidadania, redes de solidariedade e sabedoria dessas comunidades. 


\section{Meditação crítica sobre a trajetória conceitual e a prática metodológica na Favela Caranguejo}

“Mundo de ilusões, de uma irresponsabilidade mais propícia aos jogos que às lutas sociais.”

Alain Touraine, 1975

A banalização das coisas tornou-se prática comum na sociedade moderna e, em ritmo frenético, tem-nos deixado míopes. Criticamos pouco e, quando o fazemos, apenas a poucos é permitida tal façanha, por terem conquistado prestígio social inquestionável, levando à monopolização institucionalizada progressiva em forma de poder e dominação (PAZ, 1975; FOCAULT, apud MORAES, 2005). Isso se tornou claro nos trabalhos realizados antes e durante esta pesquisa no envolvimento de "pobres", em experiência de seu cotidiano, na definição de cenários futuros relacionados ao seu espaço, seja de uso coletivo ou individual. A prática disseminada nessa relação foi e continua sendo genericamente denominada de participação.

Consideramos como primordial a elucidação de algumas faces ocultas de palavraschave, para estender o alcance de nossa compreensão na relação entre tais palavras e as várias interpretações e complexidade que o termo participação e a atitude de participar abarcam, desde o mais superficial: a admiração da pintura de um artista, a apresentação de projeto de desenho urbano aos futuros usuários, até a invasão coletiva de uma área privada ou pública. A partir daí, a comunicação poderá fluir com mais clareza e transparência.

O conhecimento de tais palavras, com esta pesquisa, demonstrou nas atitudes dos envolvidos na experiência da Favela Caranguejo a profusão de entendimentos diversificados. Para o poder público, responsável pelo Projeto Social, a entrada se deu apenas quando as obras foram iniciadas, constituindo encontros breves e individualizadas. Os dados e as informações obtidas dos moradores, a partir daquele momento, foram ordenados segundo a lógica do poder público, sem serem discutidos e transformados em conhecimento 'na', 'para' e ‘com’ a própria comunidade. 'Na', porque é próprio da comunidade, dentro de um contexto histórico, considerando aspectos antropológicos; 'para', pois originados no corpo técnico e administrativo político; e 'com', porque, conhecendo-se a comunidade, trocam-se os saberes técnicos e populares, produzindo-se o saber sustentável para um objetivo partilhado.

As lacunas abertas no Projeto Social foram iniciadas no levantamento de questões que não foram alcançadas ‘com’ a comunidade. Depois, na emissão do juízo de valor para tais 
questões, também realizado pelo poder público e, por último, na priorização dessas questões e suas respectivas soluções, enquanto para o arquiteto/pesquisador, o envolvimento dos moradores deu-se a partir do histórico da área, antes de qualquer idéia de intervenção no espaço físico da comunidade. A seguir, na identificação e priorização de questões, na compreensão da situação e definição de soluções, naquilo que FREIRE nos coloca como o 'fazer histórico social'. Finalmente, no dar uma conformação para uma paisagem futura através de desenhos e outras representações de todos os participantes.

Neste capítulo, serão apresentados os pontos comuns e outros que foram de encontro ao processo empírico descrito no capítulo três e o referencial teórico apresentado no capítulo dois. Analisamos quais foram e quais as razões de atenderem ou não às prerrogativas contidas na teoria.

\subsection{Conceitos pulverizados}

Quando nos referimos à produção do espaço construído e/ou gestão do ambiente urbano, é importante definir quais os conceitos e quais as diferenças entre a aplicação e o conceito (SANTOS, 1988). Por exemplo, os parâmetros de definição da população "pobre”, para o levantamento demográfico realizado pelo IBGE - Instituto Brasileiro de Geografia e Estatística -, diferem dos das comunidades populares da COELBA - Companhia de Eletricidade da Bahia — e, por sua vez, dos assentamentos “subnormais” no PDDU — Plano Diretor de Desenvolvimento Urbano e Ambiental de Salvador: as AEIS - Áreas Especiais de Interesse Social. Tais parâmetros criam distintos aspectos e, conseqüentemente, delimitação territorial que dificulta estudos simultâneos, ações integradas e articuladas para essas áreas, quando é importante a superposição de projetos de diferentes instituições, confrontando seus respectivos bancos de dados.

Por outro lado, a definição de espaço e de como a prática humana gera esse espaço limita-se apenas a um conceito físico que não consegue dar conta de seu conteúdo social e simbólico. Como os conceitos são construções culturais, internalizadas pelos indivíduos ao longo de seu processo de desenvolvimento, para evitar seu uso de maneira imprecisa e individualizada, deve-se adotar como ponto de partida para uma dialogicidade, o estabelecimento de uma base conceitual científica. Tal base precisa envolver diferentes áreas do conhecimento, e, além do conceito, a idéia e o significado da "relação" entre os termos que se consideram a base do trabalho empírico e o que se encontra na teoria. Foi o que ficou 
demonstrado ao longo desta pesquisa. Relacionar, filosoficamente, significa dizer respeito $a$, referir-se a, ter a ver com: "toda relação supõe os termos e os fundamentos relacionais." Termos relativos são aqueles que não podem existir sem um outro no contexto dado, por exemplo, pai e filho, um supõe o outro, o fundamento relacional é a paternidade ou a filiação" (COIMBRA, 2004); entre professor e aluno há um compromisso, existem laços de interesse mútuo, em síntese, um tem a ver com o outro.

Então, uma das respostas que justificaria a atitude pelo poder público em envolver os moradores da Favela Caranguejo naquele determinado "tempo", poderia ser o conceito de pobreza. Tal conceito, mencionado no capítulo dois, está ligado à carência material, ou melhor, um pacote de carências diversas, particularmente materiais, que vem enraizado à insuficiência de renda, limitando as soluções do problema que se quer resolver, pois no estudo de caso privilegiou exclusivamente a obra física sem considerar a organização e o desenvolvimento da comunidade.

Ademais, esteve implícito o tempo todo na interação poder público e comunidade, antes e depois da presença do arquiteto/pesquisador, o conceito de participação política tradicional dos tempos gregos, demonstrando uma tendência ainda de fazer prevalecer a idéia de decidir apenas sobre o processo eleitoral, e, não apenas nas decisões em relação às intervenções no espaço físico. Durante o projeto como processo, na presença do arquiteto/pesquisador e na execução do projeto com a construtora, houve um período de eleição para deputado e governador, e, de modo contraditório assumiu o entendimento, para alguns, de fazer parte de algumas reuniões de partidos, comícios, apresentação de informação, inscrição em marchas e protestos. Nesse sentido, desdobramos esses movimentos, como explica TEIXEIRA (2000), em participação eleitoral; de movimentos sociais; de ação comunitária; de manipulação pelos governos; de controle dos recursos; e de estruturas governamentais de decisão.

A participação no estudo de caso indicou um processo contraditório, tanto no período em que o arquiteto/pesquisador esteve presente como na sua ausência, pois envolveu uma relação multifacetada de poder entre atores seja o gestor de aplicações, gestor operador, agente financeiro, agentes promotores, e moradores, e, até entre os participantes residentes. Esses aspectos, diferenciados por sua identidade, interesses e valores, se expressaram sob várias formas, conforme a capacidade desses atores e as condições objetivas do regime político em que estavam inseridos. Indicou uma tendência em que apenas a poucos é facilitada a oportunidade de participar ou mesmo co-participar. Para os moradores da Favela 
Caranguejo ficou evidente no primeiro instante em que foram chamados a participar, um ônus no poder público, de uma dependência dos moradores que se reproduziu a todo o momento. Entretanto, na fase em que o arquiteto/pesquisador mediou o processo participativo, tal ônus foi sendo reduzido com o passar do tempo, reunião após reunião. Ao início do Projeto Social, reverteu a obrigação ao poder público, reforçada ainda mais pelos próprios técnicos da área social das duas instituiç̧ões: construtora e governo.

Para o arquiteto/pesquisador uma das falhas em conduzir o processo participativo durante sua presença, pode ter começado com a falta de clareza do próprio conceito sobre participação entre os membros da equipe e entre a equipe e os moradores.

Essas falhas, ao que tudo indica, não aconteceram apenas no estudo de caso desta pesquisa, como o arquiteto/pesquisador identificou em outros estudos e experimentos. Exemplo disso, foi encontrado na avaliação do Programa FAVELA-BAIRRO da Prefeitura Municipal do Rio de Janeiro, - tal programa tinha como objetivo apresentar propostas metodológicas ao invés de desenhos, para intervir em favelas - , e diverso do estudo de caso, a prefeitura do Rio de Janeiro realizou uma extensa pesquisa, avaliando os diferentes níveis de intervenção, e, entre estes, destacou os aspectos metodológicos e práticos da participação dos usuários sob o ponto de vista da população.

Semelhantes tendências relativas às falhas também ocorreram em outros projetos em Salvador. Todos os documentos, sejam eles; o Edital do Concurso de Idéias do Instituto dos Arquitetos Bahia; o Manual de Fomento - Setor Público da Caixa Econômica Federal; e no Plano Diretor de Desenvolvimento Urbano e Ambiental de Salvador - PDDUA, em seu aspecto prioritário defendiam de modo incisivo o envolvimento, o mais intensivo possível dos moradores da comunidade que receberiam os investimentos.

Com tal aspecto, esboça na prática da gestão, que os métodos utilizados descritos nos documentos, nas entrelinhas não continham um fio condutor geral para um encadeamento participativo, o que claramente foi demonstrado, em que, por falta de transparência, a interpretação diversificada era identificada nas atividades empreendidas de cada gestor.

O caso específico do estudo de caso, o programa VIVER MELHOR/ Bahia, esteve subordinado ao PRÓ-MORADIA do Governo Federal. Em seus princípios básicos, parecia estar inteligível o entendimento sobre a participação dos que receberiam os investimentos. Afirmava que as propostas de intervenção precisariam levar em conta que nas favelas e suas comunidades, apesar de destituídas dos padrões econômicos, sociais e urbanos mínimos, 
teriam como ação principal no espaço físico, a promoção de sua integração e inserção aos bairros adjacentes e, consequentemente, à metrópole. Ademais, consideravam que, ao longo do processo de ocupação informal, haviam desenvolvido padrões sociais, culturais e espaciais com características peculiares que precisariam ser compreendidos e respeitados.

Para o alcance de todas essas considerações, defendiam a participação dos moradores no processo de "reurbanização” como atividade imperativa para a cidadania, incluindo a compreensão da "reestruturação", agora planejada, que propusesse pouca transformação da paisagem espontânea existente originalmente. Admitia o respeito ao esforço despendido pela população e, por injunção a questões econômicas, dever-se-ia aproveitar o patrimônio existente, aliado à compreensão de conceitos culturais próprios, pouco conhecidos e bastante diferentes dos padrões técnicos usuais. Nas diretrizes técnicas para a manutenção dos valores espaciais dever-se-ia preservar e destacar os elementos construtivos e urbanísticos.

Por outro lado, a interpretação e aplicação da Resolução 181/95 que respaldava em linhas gerais o PRÓ-MORADIA, esteve fundamentada na Lei 8.036, de 11 de Maio de 1990, que instituía e regulamentava o Conselho Curador do Fundo de Garantia por Tempo de Serviço - FGTS - no seu artigo 5 , Inciso I. Esta Lei considera que a Resolução 129, de 16 de Dezembro de 1993, daquele Conselho, estabelecia a necessidade de revisão dos programas de aplicação com seus recursos, o qual, tendo como objetivo a redução do déficit habitacional, resolvia aprovar o Programa de Atendimento Habitacional através do Poder Público - PRÓMORADIA. Na regulamentação do programa, a Resolução No 181, de 5 de Junho de 1995, garantia recursos para investimentos pelo FGTS, e que seriam ainda necessárias outras normas complementares, das quais ficariam responsáveis o gestor das aplicações e o agente operador: Caixa Econômica e Estados e/ou Municípios; os desdobramentos foram o edital, manual de fomento entre outros.

As operações do PRÓ-MORADIA estavam subordinadas aos critérios da Resolução 181/95 e às normas complementares do gestor das aplicações e do gestor operador. Além dos gestores, havia ainda o agente financeiro, representado pela Caixa Econômica; os mutuários estados, municípios e agentes promotores, representados pelos órgãos da administração direta e indireta dos governos estaduais, municipais. Para mais detalhes, ler a Resolução 181/95, na íntegra, contida em anexo.

O objetivo da Resolução 181/95 era apoiar o poder público no desenvolvimento de ações integradas e articuladas com outras políticas setoriais que resultassem na melhoria da qualidade de vida das famílias de menor renda, por meio da oferta de soluções habitacionais, 
da regularização fundiária e da urbanização de áreas. No caso específico da Favela Caranguejo, a modalidade, segundo a Resolução 181/95, era a letra “c”, a que se referia à recuperação de áreas degradadas para uso habitacional, compreendendo ações de urbanização, melhorias habitacionais e proteção ambiental. As modalidades constantes na Resolução poderiam ser aplicadas isolada ou simultaneamente.

Embora nas diretrizes gerais o discurso dos agentes do governo tivesse abordado a utilização preferencial de mão-de-obra local, na prática sequer mantiveram diálogo com os moradores durante a obra. Outro ponto estabelecido na diretriz da Resolução que não foi atendido foi o estímulo à autoconstrução, ou ao mutirão, e à administração direta. Houve momentos, segundo relato de alguns moradores, em que a população ajudou operários que estavam sem receber da construtora. Em outra situação, houve a troca de material definido no projeto por outro mais barato e que não atenderia às normas e especificações; os moradores, percebendo as mudanças, não conseguiam dialogar nem com a construtora nem com os técnicos do governo, e por essa razão, pediam assessoria ao arquiteto/pesquisador.

Dos pré-requisitos para participação, o Programa destacava o envolvimento das famílias a serem atendidas, na definição e acompanhamento do projeto do qual seriam beneficiárias. Neste quesito seria importante a realização de uma outra pesquisa com o poder público: os gestores das aplicações representantes da Caixa Econômica Federal — Escritório de Negócios em Salvador - Operador; a Secretaria de Recursos Hídricos Saneamento e Habitação - SRHSH e a Urbanização e Habitação da Bahia - URBIS, avaliando a compreensão que fizeram da Resolução 181/95, e quais as razões que trouxeram tanta divergência.

Os critérios por parte do poder público na seleção para a escolha da Favela Caranguejo foram ser uma área sujeita a inundações, à poluição de mananciais e fatores de degradação ambiental que colocavam em risco a saúde e a vida daquela população.

Identificamos no estudo de caso os níveis de participação apresentados por SILVA (2000). Com a coordenação do arquiteto/pesquisador, a participação interativa: a comunidade, por iniciativa do agente promotor, foi chamada a participar das decisões sobre o que iria ser feito no espaço físico da Favela Caranguejo. No segundo momento, quando se inicia o Projeto Social pelo agente promotor, a participação informativa: a comunidade apenas foi informada do que iria ser feito; e para a oficialização dos compromissos burocráticos, houve a participação consultiva: a comunidade foi informada e ouvida sobre o 
que iria acontecer, mas sem a possibilidade de decidir a respeito do que iria ser realizado; as opiniões ou sugestões da comunidade não foram acatadas pelo agente promotor.

Considerando que a participação fizesse parte da retórica dos programas citados, o que na prática se priorizou de fato foi a informação à população sobre o que seria feito para a comunidade. Reconhece-se, nestas preliminares, que informar às pessoas pode parecer óbvio, mas representa um avanço para as políticas públicas voltadas para as populações faveladas. Nesse caso, caberia uma análise do método de como se deu a transferência de tais informações. Entretanto, apontamos que há muito a se fazer por um envolvimento que seja mais efetivo e duradouro, e as razões serão temas a serem ainda estudados. Algumas tentativas de elucidar tais razões foram colocadas nesta pesquisa, mas reconhecemos que é apenas uma ínfima parte para uma compreensão mais abrangente e inconfundível.

Então, ficam as perguntas: é possível para a população brasileira, com as considerações apresentadas anteriormente, e no estágio em que se encontra hoje, uma participação capaz de fazer das pessoas sujeitos da sua própria história? E que formatação teria essa participação, confrontadas análises e reflexões teóricas com experiências participativas anteriores? E, apesar de inúmeros problemas das diferentes formas de participação, com seus aspectos positivos, possa ganhar um grande espaço na formulação das políticas públicas? Esse é o desafio que se coloca a seguir, através de uma análise sucinta sobre a participação popular na configuração do espaço urbano. O foco estará em torno dos avanços que foram obtidos durante o percurso no estudo de caso aplicado pelo arquiteto/pesquisador, daquilo que se investiu e no que se conquistou.

\subsection{Impactos sócio-econômicos e físico-ambientais de políticas públicas.}

É comum instituições de fomento financiarem projetos de impacto econômico com metodologias próprias, difundidas e testadas segundos seus próprios parâmetros, ou a falta deles, para a avaliação de resultados econômicos e financeiros. Tais avaliações incluem análises de incerteza e/ou riscos, que tentam mensurar eventuais falhas nas previsões originais. Essas metodologias têm-se mostrado distantes, tanto nos seus resultados quanto na magnitude, efeito e propagação dos seus impactos no meio em que se inserem.

O impacto social tem demonstrado uma importância maior do que o puramente econômico, pois os ganhos sociais que os projetos promovem refletem diretamente na sustentabilidade das ações empreendidas. As experiências de participação em projetos 
parecem apontar para a intensidade das ligações como relação direta de seus resultados. O diálogo franco e aberto entre corpo técnico e comunidade os torna mais confiantes entre si, interessados e motivados, levam o grupo a desenvolver responsabilidades de forma que cada qual assuma seu papel. Os agentes de fomento, como um todo, desejam e se empenham para que o empreendimento tenha o maior lucro possível, entretanto o resultado positivo dos investimentos precisa ser um exercício permanente e compartilhado de esforços, concessões, negociações mutirões, mediações, ou seja, de extensão e de qualidade da visão puramente econômica.

No estudo de caso, não foi possível criar mecanismos que permitissem acompanhar, na prática, aspectos econômicos e políticos que promovessem a compreensão da causa dos desvios, ou mesmo do fracasso do que tinha sido previsto anteriormente. Esse seria um tema para aprofundar em uma outra pesquisa.

\subsection{Elementos para formulação de respostas}

O desafio no experimento começou nos colocando na distância entre o “fazer” e a reflexão sobre aquilo que estava sendo "feito", o que nos apresentou algumas sugestões para uma próxima experiência participativa.

Primeiramente, houve a preocupação para que a experiência de campo não se reduzisse apenas a uma avaliação em termos de experiências individuais do arquiteto/pesquisador. A seguir, observou-se com desvelo ao intricado aspecto entre os tempos: o tempo real da ação efetiva e o tempo de reflexão, assimilação, acomodação e busca teórica para os envolvidos - leigos e técnicos, e o tempo burocrático que muitas vezes, no estudo de caso, apressou o processo de apreensão entre moradores e arquiteto/pesquisador. Toda essa diferença entre os tempos se constituiu em uma enorme dificuldade no experimento da Favela Caranguejo. Por último, como observador quase distante, convidado pelo poder público a retirar-se da área, o arquiteto/pesquisador era influenciado pelo que estava ocorrendo através de solicitações constantes dos moradores. De um lado, a surpreendente capacidade de aprendizagem da população em que foram lembradas as decisões do grupo para a paisagem futura, demonstrada em suas atitudes maduras de perceber, quando as obras começaram, que estavam sendo alteradas pela construtora e, por outro, sua fragilidade em continuar por ela mesma, sem solicitar a assessoria do arquiteto/pesquisador. 
Para a fase em que o arquiteto/pesquisador coordenou, ficou evidente que as poucas práticas no desenvolvimento de um modelo ideal e na construção de roteiros definindo metas a serem alcançadas, que no experimento, sempre se deram de forma intuitiva, foram um desafio, com esta pesquisa, superado apenas na teoria. Houve a falta de conhecimentos teóricos anteriores à prática participativa nos diferentes campos do saber. Os pontos de fragilidade identificados no processo participativo na Favela Caranguejo proposto pelo arquiteto/pesquisador foram:

- a indefinição da metodologia;

- a indefinição do tempo disponível;

- a indefinição do plano de execução estabelecendo procedimentos;

- indefinição dos recursos materiais;

- a falta de discussão do resultado que obtivemos através do questionário temático censitário sobre o perfil ocupacional, identificando as novas formas de trabalho, treinamento, mão-de-obra, renda e trabalho informal.

Não discutimos com eles o nível de escolaridade, não entramos em detalhes, já que foram identificados por eles os pontos de conflito, os interesses políticos, materiais e espirituais formando organizações, associações de bairro, grupo de mães, adolescentes e idosos. Não foi avaliado o grau de interação entre as diversas instituições envolvidas para qualificar o nível de relação e comunicação entre instituições e comunidade; não se conheceu a relação entre os grupos informalmente organizados, entre o grupo e a própria comunidade. Verificou-se a existência de outras propostas de intervenção que não estavam claramente definidas pelos agentes de instituições de todos os níveis, tampouco conhecidas entre os diferentes departamentos ou secretarias.

Com base nas considerações, apresentamos um gráfico de fluxo de dados para a formulação de um método que anteceda a prática participativa. Necessária se faz a definição de uma nova proposta de trabalho em que o confronto entre uma avaliação da realidade, pela comunidade, e uma situação ideal estaria bem caracterizado pela participação dos que usufruíram das mudanças físicas. 


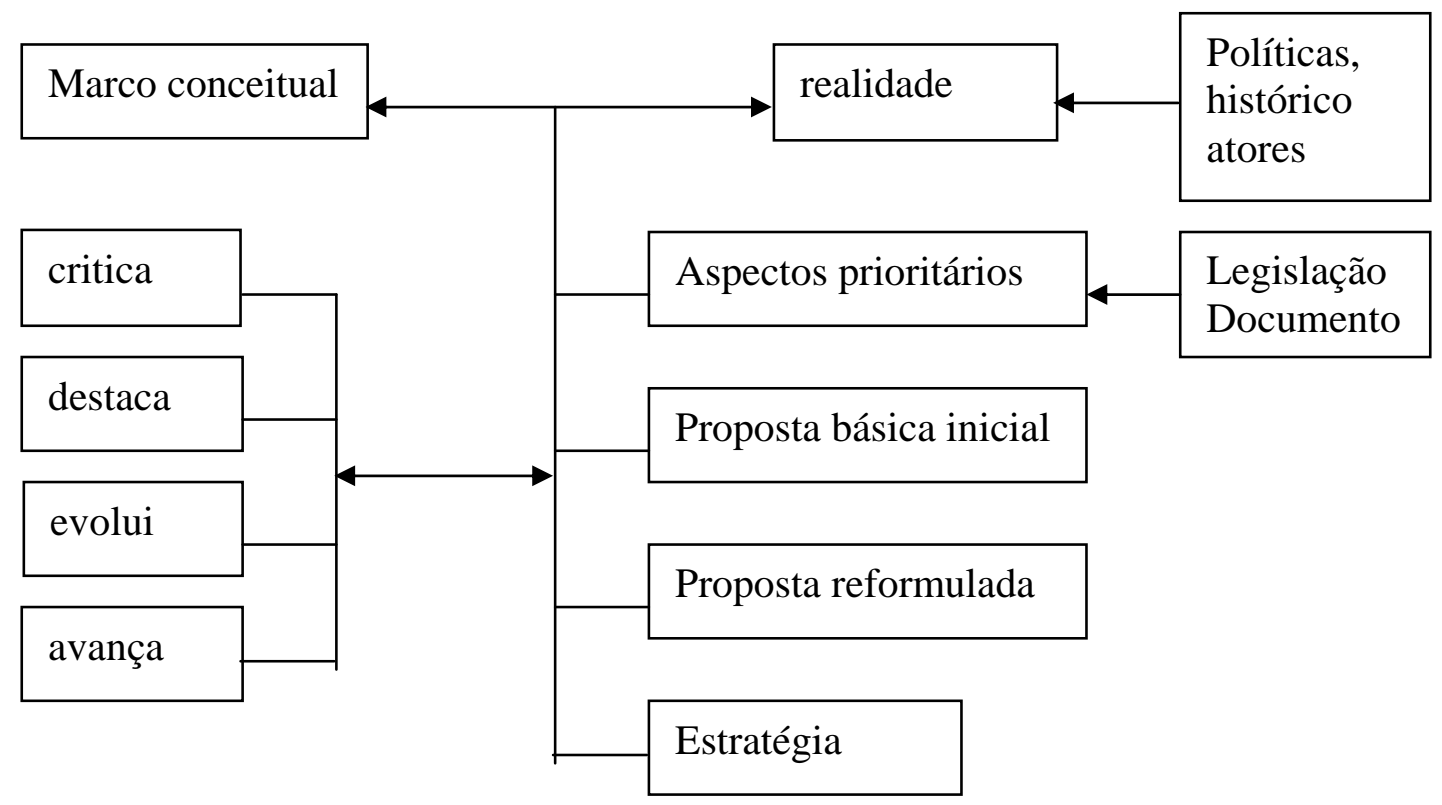

A inclusão da percepção, dos valores e das atitudes dos moradores em relação aos processos sócio-culturais na interação com os naturais identificou a maneira como eles constituíram seus espaços de convivência coletiva, salientando o potencial de redirecionamento para os sistemas que agreguem tais processos em sua base biofísica com ganhos inequívocos para ambos. A população percebeu isso e se manifestou, declarando que a legislação é transgredida; destacou sua própria referência diferente do resto da cidade, e reconheceu sua paisagem conturbada, mas trouxe significados para um cenário futuro.

Iniciou-se o processo participativo demonstrando o que, com a participação, procurouse atender, estabelecendo uma compreensão mais clara nas atividades deles nos diferentes níveis. Analisou-se conjuntamente com os técnicos quais eram as vantagens e desvantagens do processo participativo. A falha no experimento foi não ser discutido inicialmente, entre os técnicos, de que participação se estava falando, para só então ter levado à comunidade. O que associamos à palavra participação quando a escutamos? Que signos e símbolos estabelecemos quando pensamos ou discutimos a respeito desse termo?

A participação não se reduziu à apresentação das idéias, nem ao projeto pronto, foi além, destacou-se o processo de formação que se realizou a partir de experiências vividas pelos moradores, nos diversos e diferentes espaços a que tiveram acesso, na interação com os arredores e entre as pessoas, pressupondo um processo de aprendizagem ${ }^{20}$ na produção de conhecimentos.

\footnotetext{
${ }^{20}$ Pode-se entender a aprendizagem como um processo de atribuição de significados que age na intermediação entre o ser e o mundo e que, só por uma tomada de consciência profunda pela aquisição de conhecimentos, é que se faz de uma maneira imanente.
} 
$\mathrm{O}$ arquiteto/pesquisador aventurou-se às trocas dos saberes, mobilizando forças internas entre os envolvidos, de forma a que eles pudessem exercer o seu potencial na criação de seu patrimônio pessoal e de ferramenta para sua transformação, entendendo como transmissão e apropriação do legado cultural da comunidade que os conhecimentos foram construídos ao longo do tempo, dando configuração à compreensão da paisagem e à sua própria mudança. Isso significou que todos tiveram acesso aos conhecimentos diversificados, tanto da história pessoal quanto da história coletiva e essa constitui-se em fonte riquíssima de dados significativos, mobilizando as pessoas como um grupo unificado.

O processo não foi de acúmulo de informações, mas de integração, modificação, estabelecimento de relações e coordenação de esquemas de conhecimentos, entendido como objetivo da participação, a integração-reconciliação da singularidade individual com a unidade social. Cada participante tomou seu próprio significado, elaborando-o em termos de signos de apreensão coletiva. Assim, com a construção de parâmetros pessoais e de autonomia, inseridos naquele contexto geográfico, histórico e social, o morador pôde, efetivamente, aprender e usar algumas informações para o crescimento da comunidade em que vive. Adquiriu capacidade de escolha que serviu não somente para não se submeter momentaneamente à imposição de valores e sentidos, embora todas as vezes tivesse se confrontado com o poder público que insistia em não considerá-lo, como também adotou a transformação da realidade, respeitando a herança das gerações anteriores, a identidade e valores coletivos.

Essa foi a visão de mundo em que trabalhamos as diferenças mais que as semelhanças, entendendo por um lado os técnicos detentores do saber e, por outro, a população que forja a sua sobrevivência para garantir o dia seguinte. O projeto e a mudança geraram inseguranças, incertezas e riscos para o cotidiano daquela população, pois os antecedentes históricos anteriores apontavam para descaso, atrasos e má qualidade na intervenção em seus espaços, e nada demonstrava ser diferente de outras vezes.

O arquiteto/pesquisador com o processo da Favela Caranguejo procurou demonstrar que a diferença estava na pressão que juntos poderiam realizar. Entretanto, a fragilidade dessa mobilização esteve aquém do vislumbre de uma paisagem futura, na atitude autoritária e centralizadora do Estado, aliada a uma situação insustentável de falta de trabalho, de rendimento familiar, colocando em risco a própria sobrevivência, e não conseguiu despertar uma preocupação significativa e autônoma na solução para melhoraria dos espaços de lazer. 
É a constatação do que GOHN (2001) afirmou em relação aos movimentos populares, que não foram capazes de desenvolver projetos políticos, independentes e autônomos, pois se deixaram e continuam a permanecer na dependência do apoio de assessorias. Contudo, fica a pergunta: se ALINSKY (1968) dizia que o mediador deveria se afastar após a indicação de lideranças e amadurecida a estrutura organizacional da comunidade, e que jamais deveria tomar parte do movimento, então como tornar independente uma estrutura fragmentada como as comunidades populares, e, em especial a comunidade Caranguejo, se o sistema fragiliza-as ainda mais com gestão autoritária e centralizadora?

No estudo de caso, ficou evidente a situação de dependência imposta pelo poder público. Os técnicos do governo não dialogavam com os moradores, o projeto e suas adequações não foram apresentados ou discutidos e, as obras não foram concluídas. A Associação criada com o objetivo apenas de distribuição de cesta básica no governo Collor, em 1992, pouco desenvolveu sua organização interna, a burocracia e seu custo evitaram que fosse reativada em 2000, além disso, nas imediações não existiam outras organizações que pudessem dar apoio à comunidade Caranguejo. Ademais, as diferenças religiosas enfraqueciam a coesão da comunidade, impossibilitando a discussão partilhada e a construção de um consenso.

Tais considerações serviram de base para a construção de significados na prática, em que o processo de aprendizagem pressupôs estratégias que se imbricaram e se intercambiaram o tempo todo. O participante, como agente de aprendizagem, estabeleceu uma relação com o objeto, no caso, o espaço coletivo do bairro, e com ele fortaleceu as interações que antes estavam implícitas no cotidiano. Então, colocamos em prática aquilo que FREIRE (1974) escreveu em seu livro Pedagogia do Oprimido: nenhum dos presentes foi considerado um iletrado, vazio, levando-se em conta que a busca de significados que integrou o sujeito de aprendizagem com o objeto era fundamentalmente para um processo de tomada de consciência, ou seja, a transformação do "fazer” em um "compreender”. Portanto, o processo de aprendizagem esteve profundamente relacionado com o processo de interação com a realidade. Neste sentido, o enfoque fundamental do aprendizado não se situou em um problema de aptidão, mas na questão básica de atribuição de significado ao conteúdo de aprendizagem $^{21}$.

\footnotetext{
${ }^{21}$ Edgar Morin (1986). O método: o conhecimento do conhecimento. Publicações Europa-América.
} 
Como processo de aprendizagem, destacou-se uma situação problematizadora, procurando superar as contradições na paisagem com base no diálogo reflexivo, implicando para isso, um constante ato de desvelamento da realidade. A mudança gerou inseguranças, incertezas e riscos para o cotidiano das pessoas. Os antecedentes históricos anteriores apontavam para o descaso, atrasos, má qualidade na intervenção. O que o processo do experimento procurou enfatizar foi o de que a pressão com o entendimento qualificado das questões locais poderiam transformar de alguma forma aquela situação. Em que nível foi transformado, só teremos a resposta se realizarmos uma pesquisa sobre a avaliação dos impactos sociais gerados pela forma de intervenção e interação que foi possível realizar.

O momento transformador de fato - a obra - quando da realização do que foi discutido do que foi desenhado foi alijado da comunidade no momento em que, ela tenderia a interiorizar cada acontecimento de alteração no seu habitat incorporando transformações à sua história. Apesar dessa falha, foi importante incorporar os enunciados dos valores deles, pois, desenvolveram e reforçaram seu crescimento nas várias fases do processo do design.

A obra realizada pela construtora foi de encontro aos ditames oficializados no projeto executivo, ficando distante do que foi acordado nas reuniões coletivas coordenadas pelo arquiteto/pesquisador. Desarticularam-se os pontos de encontro que haviam sido consagrados pela população e reforçados pelo projeto coletivo desenvolvido pelo arquiteto/pesquisador. Derrubaram árvores, aterraram as nascentes, pavimentaram canteiros antes mantidos pela população nas vias comuns.

Portanto, um estudo pós-ocupação seria necessário para avaliarmos quantitativa e qualitativamente a ação do PRÓ-MORADIA na Favela do Caranguejo, mas, com o olhar da comunidade, para apresentar conclusões precisas e o custo das decisões centralizadoras e autoritárias.

Contraditório ao que nos apresentou o Community Design, a constituição da comunidade da Favela Caranguejo, como tarefa holística, realizou parte da empreitada na aproximação entre seus moradores e sua conexão com aspectos físicos. Os residentes da comunidade precisariam ter mais controle das ações empreendidas pelo governo, amadurecendo normas e procedimentos para com seus deveres e direitos. Então esta pesquisa precisa ir além, se pretende dialogar com o sistema instituído, utilizando vocabulário adequado, para alcance dessa meta deverá apresentar os custos, em números, das decisões desta domesticação participa(ss)tiva. 


\subsection{Pressupostos fundamentais}

A proposta deste trabalho advogou a humanização da cidade por meio da participação de seus praticantes, e a alicerçou sobre os quatro pilares da educação, aprendendo a aprender, aprendendo a conhecer, aprendendo a fazer e aprendendo a ser. Isso exigiu a capacidade de discernir, de ter autonomia e responsabilidade pessoal e social, tendo como meta um destino coletivo em que a qualidade de vida seja para todos. Sendo assim, a Educação, entendida enquanto processo político, foi voluntária, dependeu muito mais de quem a incorporou do que de quem a propôs (PELICIONI in PHILLIPPI, 2004).

A abordagem ressaltou o espaço público como oportunidade de abertura para uma gestão pública de educação da sociedade, na construção de suas políticas públicas, que tradicionalmente têm sido lastreadas na permanente ambigüidade entre institucionalização da cidadania e participação política carente, na sua aplicação prática, de rupturas com a dinâmica predominante. Ampliou os ditames contidos em leis e relatórios, aplicando na prática a interdisciplinaridade e, talvez, em um esforço ínfimo, tenha alcançado o exercício do ideário educativo de uma transdisciplinaridade, em que se privilegiou o desenvolvimento muito mais das pessoas. Por conseguinte, não se chegou com respostas prontas, programas, softwares e enlatados e, que, o que de fora ficou - impondo de fora para dentro ou de cima para baixo com a pressão de algum poder - o grupo procurou tirar aprendizagem favorável para a construção do saber popular. A abordagem foi mais situacional, construída quase sob medida para a condição específica, aproveitando-se das experiências de vida dos participantes. A solução e suas ações foram vistas como propriedade do grupo e não do outro, do governo ou do arquiteto/pesquisador, porque foi solução simples, construída passo a passo, apresentando como efeito um compromisso forte. Ainda propiciou uma conscientização dos envolvidos quanto a seus valores, e as chamadas habilidades sociais: ouvimos, falamos, observamos, negociou-se, decidiu-se, acolheu-se, entre outros. Portanto advoga-se que a arquitetura, para entender, recuperar e/ou mudar o ambiente, não deve estar limitada apenas a um projeto de intervenção física. Trata-se, antes de qualquer coisa, de um processo em que todas as partes envolvidas devem ser devidamente informadas, lenta e gradualmente.

Assim sendo, admitiu-se que para a compreensão e/ou a criação dos espaços de convivência coletiva ou espaço livre urbano, cada passo dado no design e gerenciamento procurou se tornar mais inclusivo e efetivo, com o realismo político e financeiro do momento. Para o design e o arquiteto/pesquisador, esse alcance pôde fluir melhor no entendimento da realização de seus trabalhos, obtendo um alcance maior com a realização desta pesquisa. Para 
os usuários, significou oportunidades para delinear seus espaços, contentando suas necessidades reais, e não ideais, como constam tradicionalmente nos projetos.

É preciso que se atente ao medo que algumas administrações têm de incrementar um processo mais inclusivo devido às polêmicas que acontecem. O espaço coletivo é usualmente para muitos anos, e é melhor considerar essas controvérsias no estágio do design do que na fase do espaço construído. Se o processo transcorrer de forma conscienciosa, isso será certamente um mútuo aprendizado de coleta de criatividade.

A relação que se estabeleceu na interação entre os participantes dependeu da clareza de situações para as quais o objetivo deveria ser construído e desejado coletivamente. Exigiu também uma revisão do papel do arquiteto como autor do projeto. Com esta pesquisa inferiuse que a dimensão política reboca em seu lastro a cidadania, a democracia e a educação e que, portanto, a revisão do papel de cada um dos participantes precisa inserir uma avaliação da ordem política e sua complexidade, percebendo desdobramentos em função de cada olhar e que estão arraigados em raízes históricas, carregando as palavras utilizadas no diálogo, de ruído, dificultando assim o estabelecimento da comunicação entre os participantes. Por outro lado, o vocabulário e seu significado devem ser compreendidos por todos, para não limitar a abrangência do problema e a complexidade do que se quer realmente resolver, pois isso qualifica as atitudes dos envolvidos diante desse entendimento.

A sociedade precisa comprometer-se com a garantia de forjar no seu cotidiano uma cidadania ativa e plena para todos os seus habitantes utilizando como estratégia primordial, a participação de todos. Para alcançar o estágio de cidadania plena, a participação deve buscar a colaboração, negociação e o diálogo com os diferentes setores sociais, que seja capaz de influenciar as políticas públicas, em especial, as de tendência à redução da desigualdade social.

O problema de fundo que a concepção da cidadania vem nos apresentando é que a sociedade sempre foi e ainda é dividida em classes, que existem cidadãos proprietários dos meios de produção e cidadãos despossuídos; que os interesses da maioria explorada não são os mesmos da minoria exploradora. E que essas divisões ao longo da História têm nos demonstrado que os lucros de uns implicam a falta para outros. Omitir essa oposição em nome de uma pretensa "igualdade entre todos a ser atingida” dentro da sociedade atual desvia a sociedade na busca da necessária unidade para mitigar a espoliação. Essa luta exige maturidade e nitidez na tradução de um cenário mais real diante do significado das informações apresentadas, considerando o processo de apropriação visto anteriormente. 
A estratégia da cidadania que se propõe a defender os direitos conquistados sob esse nome difunde a visão, no interior dos movimentos sociais, operários e ambientais, de que é possível uma melhoria para todos baseada na ação conjunta com toda a sociedade. Nada novo, apenas a velha política da colaboração de classes com outra roupagem. É uma dialética complexa e real: de um lado, a cidadania considerada como algo pleno e de toda a sociedade, que só poderá ser realmente alcançada com uma política de classe, do outro, a defesa da união de todos pelo bem comum. A aceitação do poder estatal burguês travestido de Estado de Direito como único horizonte possível, além de utópica, não permite sequer a defesa conseqüente desses direitos. É como se todas as contradições do sistema capitalistaimperialista pudessem ser resolvidas mediante a conscientização, as ações locais e o convencimento pelo diálogo. Seria fácil. Mas o capitalismo não deixa saída. A história da humanidade continua sendo a história da luta de classes.

O aprendizado no processo participativo da Favela Caranguejo teve um alcance importante para os moradores e arquiteto/pesquisador, na descoberta e conscientização das questões, na valorização dos pontos favoráveis do lugar, na idéia de pertencimento encorajado pelo diálogo e no debate enfatizando a colaboração de todos. A apresentação da diversidade de expressão de todos mostrou com clareza algum sucesso para o empreendimento. Será necessária, complementando o estudo pós-ocupação citado anteriormente, uma análise do entendimento do que é participação e quais os pontos relevantes que ficaram de todas as reuniões, abordados pela população. 


\subsection{Visão de mundo e desafios propostos}

Como faria se um novo projeto participativo fosse lançado?

Para o desafio de humanizar a cidade, o arquiteto procuraria democratizá-la, instalando o cidadão no centro de decisões. Inicialmente abrindo "espaços” para o exercício pleno da liberdade, da criatividade para a fruição de seus habitantes, criando condições que privilegiassem os que menos as têm, garantindo que se apropriassem delas, imaginassem-nas, vivessem-nas, desfrutassem delas e a transformassem. Em seguida, explorando as funções que o planejamento e a arquitetura da paisagem oferecem como instrumentos de gestão, consideraria não apenas os limites no processo de gestão encontrado na teoria, mas também nos empreendimentos experimentados.

Incorporaria os novos fatos que vêm ocorrendo e que modificam lentamente a forma de enxergar o mundo, definirem métodos de pesquisa, de trabalho individual e, principalmente, coletivo. Além disso, sua atualização exigiria o diálogo entre os diferentes campos e formas do saber, exercitando a atitude e a prática interdisciplinar.

Outro desafio seria a construção do saber popular, de forma mais organizada, incorporando o conhecimento das assessorias. A forma de como construir esse saber deve ser motivo para uma discussão com o próprio grupo em estudo, destacando que a promoção, a comunicação e a divulgação desse saber, investidos num processo de educação política, é ganho de consciência, e compreensão de todo o processo para o progresso de todos.

Por todos os motivos expostos anteriormente, é imprescindível eqüidistar o descompasso entre o trabalho físico no canteiro da obra e o trabalho social, contrapondo-se ao discurso de alguns autores em que afirmam a impossibilidade de trabalhar a cidadania junto com o processo de formação diretamente no nível da produção (SALVADOR, 1994).

Discutir as bases de conteúdos subjetivos é vital, - Plano Diretor, Agenda 21, Estatuto da Cidade, entre outros —, afim de ratificar-se uma consolidação no mundo real e concreto, na forma como a conjuntura nos permitir e nos apresentar. Como conseqüência fazer com que o arquiteto conceba uma prática da vida e história de seu tempo, produzindo um projeto social, instrumento capaz de fazer as mudanças necessárias para transformar o mundo social e ambiental.

É importante, advogar pelos que não têm voz e de poucos recursos, sem ter a visão ingênua e romântica sobre o fenômeno da favelização, estudando-o através de conceitos 
claros, derivando lições e exemplos aplicáveis a um design que esteja melhor adequado à realidade local.

É ainda nosso papel, reconhecer as desconformidades essenciais entre atuação, informação, teoria e legislação, admitindo que a atuação e a informação são específicas de um momento e lugar, e que a teoria e a legislação, ao contrário, são generalizações. É preciso atentar para as variações que se registram em distintos contextos, e que a diferença relativa entre ambas as instâncias sempre existirá, que o fracasso dos programas e projetos sociais do governo se deve às tensões originadas pelas imposições das mesmas especificações generalizadas a pessoas e situações completamente diferentes.

Precisamos observar que as leis, as normas, os manuais, os editais e outros documentos usualmente têm sido confundidos com os procedimentos operacionais, e, as questões e teorias têm sido mescladas com os problemas sociais da vida real. Nesse momento, verificamos que o fio condutor fundamental entre os campos de atividade local e geral são as análises que se faz de uma situação simulada e o design. Enquanto o analista comprova a teoria confrontando-a com a informação obtida, o designer traduz as normas em atuações específicas, as duas atividades se complementam e são dependentes mutuamente. É importante certificar-se de que o poder normativo fixa as regras e o poder operacional aplica as regras, e que os problemas práticos que desafiam qualquer política social tratam do estabelecimento de estratégias efetivas para o planejamento - os métodos —, a identificação dos instrumentos adequados para a prática - os meios —, e a definição dos objetivos próprios de uma prática realística — os fins.

Devemos discutir sobre o entendimento do termo "comunidade”. Genericamente se refere à existência de grupos de pessoas que interagem socialmente com algum vínculo ou compromisso comum, e têm o propósito do encontro de necessidades individuais e a obtenção de metas do grupo (BELL; NEWBY, 1971). Essa comunidade estaria limitada a uma área geográfica.

As características da interação social, das estruturas para a satisfação física, para as necessidades social e psicológica, e a limitação geográfica são a base da definição de comunidade. Indica também uma conformação de modo de viver, de como as pessoas fazem seu cotidiano, o que querem suas instituições e suas metas coletivas. 
As pessoas em uma comunidade devem não apenas estar habilitadas "para”, mas frequentemente atuarem juntas sobre as mesmas preocupações da vida (SUSSMAN ${ }^{22}$ in BELL, 1971). No modelo de interação de KAUFMAN existem três elementos da comunidade: a participação comunitária; as associações e grupos comunitários e, finalmente, a fase e o processo de ação comunitária, ou seja, “quem”, “com quem”, “fazer o que” e “quando”. Na atualidade, a comunidade é bastante dependente das variáveis, a exemplo das características das políticas locais. Quanto à localização territorial de pessoas, segundo PARSON $^{23}$, não significa uma determinação exclusiva ou predominante, mas como foco de atenção observável, e analisável. Um determinante parcial.

\subsection{O Cenário e a criação da comunidade futura}

A ênfase de muitos autores em envolver os usuários no processo de construção da habitação e/ou dos espaços coletivos é vista como único caminho para encontrar as necessidades dos usuários, especialmente nos assentamentos informais. ALEXANDER (1985) argumenta que o fundamental no processo de construção desses espaços está no princípio de que os habitantes dispõe deles em sua ordem própria, daí que envolvendo-os, ou seja, buscando interiormente essa ordem e trazendo-a para o projeto, torna-a uma peça fundamental na indicação de caminhos que possam reduzir muitos conflitos e problemas.

Outro autor, GIBSON (1990), ainda afirma que a experiência de clientes e o conhecimento profissional são importantes para ambos. Sem essa troca, as soluções ditadas apenas pelo profisional tendem a ficar fora do ambiente cultural e social do usuário. Para SANOFF (1990), com o envolvimento do usuário no processo de habitação, os técnicos têm que estar abertos a uma nova capacidade de abordagem, diferente da convencional. Além disso, essa aproximação permite ao profissional considerar características que facilmente passam despercebidas, mas que são muito importantes para o usuário. Pelos argumentos acima, um eficiente envolvimento do usuário se constitui uma necessidade para permitir previsibilidade de vantagem em uma efetiva responsabilidade social da profissão e dos praticantes da cidade (HINRICHS, C. apud ABDEL-AZEEM, 1996).

Enquanto a participação ideal vem sendo destacada em trabalhos e publicações, a maioria das experiências de participação no campo real não alcança esse ideal, sendo

\footnotetext{
${ }^{22}$ Marvin Sussman (ed), Community Structure na Analysis, New York, Crowell, 1957

${ }^{23}$ T. Parsons and E. Shils, Toward a General Theory of Action, London, Harper Torchbook, 1952.
} 
freqüentemente limitadas por algumas escolhas autoritárias. Contudo, essas restrições podem ser denunciadas através de coletâneas de opinião e podem subsidiar a experiência dos próximos projetos participativos, recordando a situação anterior de participação especialmente, sua racionalidade e resultado - como fonte crítica para o avanço do entendimento e prática de participação.

No processo de constituição da Associação dos Moradores da Favela Caranguejo, fundada em 1992, não se pôde dar continuidade a um processo de desenvolvimento de caráter educativo. Primeiro pela própria intenção quando levou seus moradores a constituírem a instituição oficial, a distribuição de cesta básica. Depois, pela experiência gerada no contato com fontes de exercício do poder; ou ainda em virtude da aprendizagem pela repetição de ações rotineiras impostas pela burocracia, o que não permitiu essa aprendizagem com as diferenças existentes na realidade social entre a comunidade e o resto da cidade, a partir da percepção das distinções nos tratamentos que os diferentes grupos sociais recebem em suas demandas.

Existe também a percepção, pela comunidade, do caráter do poder público, dos partidos ou das instituições, nas relações subordinadas de tutela ou de cooptação que esses estabelecem com aquela, mas ela se vê na inércia, portanto, sem o poder de conseguir alguma mudança. Não se realizou articulação com outras organizações, apesar de existirem fortes movimentos, a exemplo da CAMPI - Comissão de Articulação dos Moradores da Península de Itapagipe; Sociedade $1^{\circ}$. de Maio de Novos Alagados, além de que existe, na própria favela, uma disputa de fiéis entre diferentes cultos religiosos: candomblé, presbiterianos, Assembléia de Deus, entre outros.

O poder público acentuou mais a fragmentação da pouca iniciativa e desenvolvimento organizacional da comunidade, que arraigados ainda da época da distribuição da cesta básica, permaneceram na dependência do apoio de políticos, gerando apenas interesses individualizados, reforçados pelo Projeto Social do Programa VIVER MELHOR/PRÓ MORADIA aplicado pelas assistentes sociais da URBIS/CONDER. Quanto às assessorias, segundo declaração dos próprios moradores, na história dessa comunidade, apenas ocorreram no período em que o arquiteto/pesquisador desenvolveu o projeto participativo. Apesar do quadro de carências políticas e materiais, os resultados do processo de aprendizagem nas práticas urbanas, que precisariam ser mensurados em uma outra pesquisa, foram surpreendentes. 
A construtora e o poder público, quando entraram na área, foram bombardeados com inúmeras questões não apenas de interesse individual, como as de ordem técnica que havíamos definido no projeto. O diálogo foi limitado e não conseguiu reverter os resultados finais da obra.

As categorias e variáveis como a organização política, ou seja, uma organização do grupo com ajuda das assessorias de técnicos, políticos e religiosos teve oportunidades de ser realizada apenas no período conduzido pelo arquiteto/pesquisador. Com o início das obras, portanto, a entrada da construtora e do projeto social executado pelo governo, tal organização foi desfeita, os encontros passaram a acontecer no escritório instalado pela CONDER/URBIS não mais em ritmo coletivo e, sim na resolução de problema individual. A cultura política, fundada na participação através da construção de canais em que houvesse liberdade de expressão, pluralismo, a exemplo dos conselhos, do orçamento participativo, entre outros, apesar de existirem na cidade de Salvador, e por ser uma exigência para repasse de verbas para os governos estaduais e municiais, esteve longe de acontecer; na própria comunidade pouco se conhecia a respeito dessas práticas.

Quanto à historicização das lutas levadas ao reconhecimento coletivo do ambiente construído, do espaço gerado, essas vêm sendo apropriadas na luta cotidiana, em festas populares e encontros religiosos ou comemoração de alguma conquista no espaço, no local de comemoração comunitário, em que as representações fortes no imaginário popular acontecem. Nesse momento, a solidariedade se espalha e as diferenças são bem pouco visíveis.

Dessa comunidade tiveram poucas experiências de movimentos específicos pela moradia ou equipamentos urbanos, e mesmo na época em que a construtora interrompeu duas a três vezes a obra, a iniciativa da comunidade foi a de recorrer ao arquiteto/pesquisador para saber o que deveriam fazer. Os momentos de mobilização aconteceram através de abaixoassinados e a ida de alguns representantes à sede da CONDER/URBIS, em que os moradores pediram satisfação pela parada da obra. Isso ocorreu três a quatro vezes, o último apelo da comunidade, referiu-se à demora para o retorno da construtora após paralisação dos serviços. E, por final, a conclusão dos trabalhos que ao que tudo indica e aos olhos dos habitantes da Favela Caranguejo, não foram concluídos, deixando a área em desordem.

Ainda que a atitude do governo em reurbanizar as favelas venha dos anos 70, inicialmente simplificada através de fornecimento de água e luz, na atualidade ainda permanece dessa forma, reforçando a lógica de fazer pagar os custos de fornecimento e de 
implantação dos serviços, sem a preocupação de realizar avaliação e análise da complexidade das questões extrínsecas ao quadro estrutural do país.

As exigências, a eficácia e a valorização dos espaços de gestão participativa podem ser vistas também pelos novos desafios das lutas sociais pela questão ambiental. Entretanto, a tendência do pleito participativo na política neoliberal tem sido implementada no sentido de desobrigar-se o governo de encargos sociais, principalmente, os que não privilegiam o fortalecimento da cidadania, retornando aos favores e à caridade. Nesse processo está a privatização, a utilização dos conselhos ratificando políticas municipais supostamente progressistas, e possibilitando repasses de recursos submetidos ou supostamente submetidos a um controle social.

No estudo de caso apresentado, o cuidado especial na comunicação entre os participantes promoveu condições favoráveis para a participação no reconhecimento do processo histórico entre a ocupação humana e a mudança da paisagem. A tentativa de aplicação do método participativo teve flexibilidade, em razão da variedade de problemas que apareceram em diferentes camadas da população, das diferenças locais, tal como a maneira pela qual as pessoas se organizavam para ter sua visão de mundo e construir seu conhecimento, e de como reagiam às outras propostas apresentadas a elas; além da própria limitação de recursos da equipe coordenada pelo arquiteto/pesquisador, seja de ordem financeira, seja na questão material, por não fazerem parte do escopo acordado com a URBIS/CONDER.

Então, se o processo participativo pode ser facilitado dependendo da estrutura política vigente, no caso da Favela Caranguejo o poder instituído deflagrou uma pseudo-participação, significando que os governos central e local não permitiram ao público compartilhar de nenhuma forma da tomada de decisão. Essa afirmação não tem base apenas no estudo de caso Favela Caranguejo, mas em outras experiências de que o arquiteto/pesquisador participou com a administração pública em Salvador. Conclui-se, portanto, que se o técnico deseja incorporar em seus projetos as necessidades dos praticantes da cidade, precisa estar consciente dos políticos, das tomadas políticas e sua implementação no governo local.

Os governos comumente emperram em seus propósitos, sejam quais forem os fatos e argumentos apresentados contra eles, reforçados ainda mais pelo seu insucesso em atingir os objetivos estabelecidos no desenho dos programas, dos projetos e das políticas públicas. Insistem em defender que, com base em um diagnóstico prévio essencialmente correto e em um sistema adequado de informações na fase de formulação e definição de metas, recursos e 
horizonte temporal da atividade de planejamento, são capazes de aferir a eficiência dos programas ou políticas e seu grau de eficácia. Como isso não acontece, o caminho mais fácil é justificar o fracasso na política. Decorre daí a criação de novas propostas, sem haver a compreensão extensa dos fatos já ocorridos, sempre partindo de uma falsa idéia de que a informação está perfeita, a coordenação é perfeita, há total controle, hierarquia, clareza de objetivos, reforço de regras perfeitas e uniformes, linhas únicas de comando e autoridade, além de legitimidade política e consenso quanto ao programa ou política.

Se as peças não estão coesas e ajustadas, isso facilita sua operação de forma até contrária aos objetivos do programa. Ou seja, a diversidade de contextos de implementação pode fazer com que uma mesma regulamentação produza impactos inteiramente diversos em diferentes locais. Tal característica aparece na experiência na Favela Caranguejo.

Reconhecendo as distorções do estudo de caso, há ainda a consideração de que os projetos sociais adquirem uma conotação idealística e menos empreendedora, dando conformação em função do tipo de projeto, do tipo de cliente atendido, dos objetivos que são esperados e resultados que devem ser alcançados.

Além de o termo 'participação' passar por uma generalização de conceitos, não teve um alcance de outros sinônimos, como envolvimento cidadão, influência cidadã, grupo de ação cidadã, cooperação, codecisão, autodecisão, entre outros. Ter voz e ou ter o poder de decidir é a questão crucial que define a relação entre mundo profissional e o mundo das pessoas leigas e aonde se quer chegar.

O pluralismo, a descentralização e a autonomia local não convivem com o sistema, o tempo todo vêm criando uma intensidade de instituições locais para as pessoas, em que continuam excluídas do processo devido à burocratização exacerbada, mantendo a centralização e, especialmente, o controle e a manipulação de informações. E ainda deflagra uma enorme fragilidade, inicialmente interrompendo a iniciativa espontânea de qualquer movimento em direção a participação efetiva, e a seguir impondo uma mobilização em torno de interesses baseados em idéias da instituição, ao invés do interesse imediato da própria população.

Com todo este cenário aparentemente centralizador, o processo na Favela Caranguejo, não apresentou apenas situações desfavoráveis. Alcançaram-se estágios de nitidez “do que era” e, do que se queria de tal participação, conseguiu tirar de cada um dos envolvidos informações preciosa para melhorar a visão de coisas da coletividade, capacitando-os a lidar 
melhor com esse mundo difuso e desigual. Precisaríamos realizar uma avaliação do ponto de vista da comunidade em relação a todo o processo, destacando os ganhos e os desperdícios, inclusive o Projeto Social incrementado pelo governo no papel das assistentes sociais. Certamente, as obras que não foram bem concluídas irão influenciar o resultado da pesquisa.

No que se refere ao poder da comunidade, ela não se reconheceu com força ou poder de qualquer espécie. Com essa falta de auto-estima teve pouca iniciativa para eleger suas lideranças. Será que é possível consolidar e amadurecer alguma estrutura organizacional e retirar-se da comunidade? Na estratégia de ALINSKY, o organizador jamais deveria tomar parte no movimento, mas como não tomar parte no ínfimo movimento, se a força governamental esmagava a população moradora de favela?

Com isso, a constituição organizadora comunitária, em relação às suas questões, sejam a da moradia, de escolas, de serviços e de redes públicas da cidade, não apresentou qualquer poder para reverter a tendência em direção à desintegração do grupo ao conseguir seus objetivos mais imediatos. Ao que tudo indica, o controle da comunidade alcançou suas metas em algumas instâncias.

Generalizaram-se idéias; identificaram-se atitudes; disseminaram-se informações; resolveram-se alguns conflitos identificados; revisaram-se propósitos, mas na segunda fase do processo em que o arquiteto/pesquisador não estava mais na coordenação, o caminho tomou outra forma. Os objetivos, e porque as pessoas teriam que ser envolvidas, identificaram alguns pressupostos para o método participativo, além do momento em que os participantes deveriam ser envolvidos, ou no desenvolvimento, durante a implementação, ou na avaliação e até em algumas dessas combinações.

No estudo de caso, o arquiteto/pesquisador diminuiu sua influência através do contar histórias pelos moradores mais antigos, os fatos marcantes; as datas festejadas, a descrição e a imagem do bairro ao longo dos anos. O perfil da participação esteve muito em função do caráter do projeto e do período em que essa participação pôde ser requisitada no processo. Positivamente, iniciamos o envolvimento dos cidadãos da favela, antes do projeto de desenho urbano sequer está na cabeça do arquiteto/pesquisador, o design a várias mãos. Com a possibilidade de concretização das idéias discutidas com a realização da obra, gerou um processo de aprendizagem construtivo, em que a cada encontro mais pessoas queriam dar sua contribuição. 
Tanto a pesquisa realizada por SILVA (1999) como a experiência da Favela Caranguejo, no entendimento da administração pública, indicou que a prioridade foi apenas um processo de informação à população sobre o que iria ser feito na comunidade, sem possibilidade de mudança por ela mesma. Explica-se assim a razão pela qual o método aplicado pelo arquiteto/pesquisador foi alterado, quando o governo entrou com o Projeto Social. Nesse sentido, essa participação, em que o controle do projeto permanece na mão das instituições, é uma pseudo-participação. Evidenciou-se que nesse nível de envolvimento, as pessoas presentes apenas ouvem o que foi planejado para elas.

Os principais pontos destacados na constituição comunitária na Favela Caranguejo passaram pelo envolvimento dos presentes na definição do cenário, na priorização dos objetivos e na escolha das estratégias para alcançá-los. Durante o processo, foi importante destacar os ganhos e o que a comunidade deixou de ganhar. Embora o tamanho da comunidade pudesse facilmente gerenciar o trabalho, houve muitas dificuldades para manterse estável, coesa e consistente, entre esses motivos destacamos a assinatura do contrato entre a instituição e o arquiteto/pesquisador, a demora do poder público em analisar o projeto executivo. A seguir, o longo período de espera para a contratação da construtora e poder dar início às obras. Com isso aumentava em proporção geométrica a descrença de que realmente as obras iriam acontecer.

As parcerias criativas foram pontos encontrados na teoria que não aconteceram no estudo de caso, nem com as instituições existentes na cidade, nem com organizações filantrópicas, nem com outras associações de bairro do entorno.

No percurso, os interesses individuais e os do grupo apareceram ao mesmo tempo em que as pessoas expressavam suas opiniões e visões abertamente, mas comprometeram-se a apresentar soluções que pudessem ser aceitas por todos que estivessem preocupados em resolver questões do bairro.

No reconhecimento do interesse comum, veio a construção do consenso de maneira mais sutil. Os participantes entendiam e permutavam os interesses entre eles, sem necessariamente estarem de acordo com tais interesses. Havia uma limitação no processo de discussão pelo prazo de entrega do projeto executivo, da realização das obras, e muita insegurança quanto ao poder de decisão do arquiteto/pesquisador, por não ser representante do Estado. Por essa razão exigiam a presença do poder público, que apareceu em apenas duas reuniões. 
Os participantes tiveram mais ou menos oportunidades iguais, considerando o grau de desconfiança pela própria situação de irregularidade. As hierarquias foram abolidas, alguns participantes assumiram o poder de orientar sobre temas discutidos nos encontros, assim como interferiam quando a competição se instalava, resgatando o interesse comum do grupo.

No processo participativo da Favela Caranguejo, a decisão colaborativa encorajou a criatividade, abriu os canais de comunicação, ampliou o envolvimento de pessoas e, conseqüentemente, reduziu conflitos quanto à complexidade de problemas e diversidade de interesses. Algumas perguntas foram abordadas, a exemplo de: Por que o processo era necessário? Qual a maneira de resolução exigida? Como o grupo trabalharia para perseguir seus objetivos? Contudo, outras não foram tratadas: como as decisões seriam tomadas? Qual o calendário? Quem receberia e colocaria em prática o produto final?

A base comum de informações foi imprescindível para inicialmente criar um clima de menos desconfiança e, a seguir, apresentar soluções para determinado problema. As discussões trouxeram o aclaramento do problema para todos os participantes, refletindo dessa maneira uma preocupação de todos, adequando um gerenciamento dentro do prazo e dos recursos disponíveis.

Para definição do problema, os métodos, além da descrição verbal, utilizaram imagens antigas, fotos aéreas, documentos guardados por moradores mais antigos, reportagens em jornais, mapas cartográficos, painéis, relatórios, que ajudaram numa compreensão coletiva sobre o problema físico.

Alguns profissionais afirmavam que os participantes não teriam conhecimento suficiente para discussão, mas isso dependeu da capacidade de ouvir de cada participante, seja ele morador ou profissional. A complexidade técnica das questões do planejamento e do desenho urbano e seus problemas não desencorajaram ou inibiram a participação, em que a habilidade do arquiteto/pesquisador era sempre testada. Como a apropriação se deu de maneira simples, aproveitando a intervenção dos próprios moradores, aos poucos as informações técnicas eram inseridas indiretamente e depois enfatizadas, inclusive com termos do vocabulário específico de cada área profissional.

Certamente, o envolvimento dos usuários precisaria de mais tempo do que tivemos, e seu custo limitado não pôde contar com profissionais com experiência ampla e conhecimento especializado em mediação de conflitos. A falta de perícia dos profissionais, da administração pública e de gerenciadores dos trabalhos para aceitar a colaboração dos usuários limitou a 
efetividade da participação de todos. Um consultor externo certamente facilitaria o processo participativo e capacitar os profissionais e a administração local.

As pessoas envolvidas não representavam a maioria, mas elas eram mais que cidadãos que representavam algum interesse especial. A participação cidadã ao que tudo indica tem fraquejado porque a influência dos cidadãos envolvidos no processo tem sido pouco inteligível, e o processo é ineficiente em trazer o cidadão para tomar decisão de fato. A participação foi distribuída na comunidade Caranguejo igualmente, uma das razões foi o fato de que os temas em sua maioria eram propostos pelos participantes locais gerando qualidades que permitiram a muitos participar, a motivação, as habilidades e os recursos. Por outro lado, os fatores que inibiram a participação mais expressiva incluíram a necessidade individual que algumas vezes sobrepujava a coletiva, o baixo senso de eficácia das atividades públicas, a demora e o excesso de burocracia.

\subsection{Considerações}

Para responder a uma variedade maior de questões, procuramos desenvolver neste trabalho um conjunto de valores e princípios compreensíveis. Sinalizaram-se alguns caminhos, mostraram-se pequenas brechas e, sobretudo, indicou-se a necessidade de um gesto e atitude ousados pelos quais será possível aprender a estender do individual competitivo ao comunitário cooperativo. Nesse sentido, nossas reflexões, se bem fundamentadas, serão vitais e trarão pressupostos que a todo tempo precisam ser revisados para darmos pequenos e cautelosos passos.

Reiteramos o que afirma a maioria dos autores sobre uma crise dos paradigmas e, com ela, do próprio vocabulário necessário para estabelecer a comunicação. Em uma das faces, precisa-se analisar, avaliar e reconsiderar os nomes que damos às coisas: crise energética, crise urbana, crises ambientais, crises populacionais, reconhecendo que todas estão arraigadas numa crise maior que é a nossa percepção estreita e inadequada da realidade, devido à insuficiência e ao retalhamento de nosso conhecimento. Isso nos tem levado sempre, nas poucas tentativas de integrar todos os pontos de vista e todos os interesses, a diferentes caminhos, mostrando-se uma tarefa quase impossível. Esse é um empreendimento com o qual todos nós teremos que nos comprometer. Nesse processo individual estão implícitos questionamentos sobre a nossa herança de visão de mundo, ainda fundamentada no arcabouço cartesiano. 
Para ilustrar essa dificuldade, neste estudo verificou-se que muitas expressões vêm sendo usadas como mote da boa sociedade, simplificada, banalizada. Pensar os problemas globalmente exige conhecimento científico, discernimento das informações e de seus significados, além de uma dose de perspicácia política. O que vem acontecendo tradicionalmente é que em reuniões, inclusive internacionais, deparamo-nos com cientistas e tomadores de decisões, ainda sendo de mesmo país, que não conseguem chegar a bom tempo. No outro extremo, no caminho reverso, os políticos muitas vezes têm encomendado documentos científicos que expliquem e respaldem suas decisões.

Daí decorrem os jogos de trocas e persuasão de outras maneiras, que não necessariamente pelo uso da força para impor a vontade, acontecem os blocos por interesse, que aliados ao paradigma em que a ciência e a tecnologia têm criado, resolvem as questões de quem pode financiá-las. Até agora, essa tem sido a lógica, que precisa avançar na direção de discutir e estabelecer procedimentos éticos no trato com as questões complexas, e estender o diálogo aos seus benefícios e riscos, incluindo a sociedade na sua totalidade.

Em decorrência das falhas nesse pensamento, a visão de mundo ainda trata o espaço coletivo como utilitário, não como patrimônio da coletividade. A transição à democracia brasileira e emergência e recriação das lutas pela cidadania ainda não descarta a ótica sobre a dívida social acumulada nas décadas 60 e 70, carregada de uma relação intricada ambígua e contraditória. Isso dificulta muito a interação com a população de poucos recursos. Tal atitude traz no seu bojo uma idéia de participação democrática que tem invadido numerosas áreas na vida social através dos discursos, normas, legislação, procedimentos, com poucas exceções, tradicionalmente em sua prática no encorajamento de uma baixa qualidade na ação cidadã, transformando em fetiche apenas uma única forma política de participar que é votando, limitando a democracia como um procedimento apenas para eleger as lideranças governamentais.

Então nos vem a pergunta imprescindível que terá resposta atendendo ao alcance proporcional às soluções procuradas. Por todo esse cenário contraditório: de que participação se está falando? SATTO (2003) recorre ao poeta mexicano Otávio Paz, no seu livro Labirinto da Solidão, afirmando que quem já viu a esperança não quer buscar outra coisa nas lutas cotidianas. É um conforto, não apenas para que os argumentos científicos ganhem mais espaço, mas também para que a sociedade deseje que todos pratiquem uma democracia madura, forjada, defendida, responsável na sua diversidade ambiental e justa em suas diferenças. 
E, como sintoma do desafio que representam novas práticas no que diz respeito à questão ambiental, todas as problemáticas e reformulações esboçadas nesta reflexão, e tendo como norte o envolvimento da comunidade, contrapõem-se aos discursos habituais de que a cidade informal ou a parte da cidade que abriga os assentamentos informais vem sendo responsável pela redução dos recursos ambientais naturais, conseqüentemente, reduzindo a qualidade de vida global. Da mesma forma, devemos acatar com menos relevância, que a densidade demográfica e, portanto, os “pobres”, tem contribuído para crise ambiental, pois mais do que o crescimento populacional, têm sido os padrões de consumo e emissões insustentáveis dos países industrializados.

Ponderando sobre novas práticas, precisamos igualmente refletir sobre o papel para o arquiteto, diferenciado do que tradicionalmente vem ocorrendo, enfocando nesse novo papel a tarefa de facilitar, escutar e inventar, auxiliando nas descobertas de instrumentos capazes de desmistificar o efeito simbólico que tem sido exercido pelos especialistas. E na continuidade, favorecer o aparecimento das condições organizacionais para a produção coletiva da intenção de propor e/ou inventar um projeto político, assessorando todos a saber e a poder escolher, efetivando suas escolhas. Ou seja, facilitando e/ou promovendo o surgimento das condições organizacionais para o sucesso da invenção de um dado projeto político, e esse certamente será um projeto coletivo.

Nesse sentido, tal profissional, após escutar, deverá investigar, com o cuidado de não chegar com lições, nem ensinar a pensar, permanecendo o tempo todo a inventar maneiras de tornar menos frágil a estrutura social existente. Com a missão de auxiliar, valoriza e aproveita o saber que todos detêm, proporcionando instrumentos que questionem o efeito simbólico exercido pelos muitos especialistas em seu “discurso competente”, comprometido com uma política de globalização. Como empreendedor, deve procurar favorecer o aparecimento das condições técnico-organizacionais para uma produção coletiva com a intenção de engendrar um projeto político e, para não parar no meio do caminho, corroborar o surgimento das condições técnico-organizacionais para o sucesso da invenção desse projeto político, mitigando os tantos obstáculos ocorridos no caminho.

Esse empreendedor conforma-se então como um excessivo e curioso sujeito interessado em partilhar o entendimento da percepção de seus clientes, em como reagem e a usam em relação ao ambiente urbano. Além disso, como eles modificam, delineiam esse espaço físico e como esse espaço afeta a forma como constroem seu cotidiano. O valor de uso dos espaços coletivos não se deve medir em termos de melhor ou pior adaptação, e sim pela 
utilidade que reportará aos seus praticantes. E ainda, como grupo, deve procurar o desenvolvimento de uma consciência que derivem algumas lições para um determinado projeto, programa, política, planejamento, proporcionando todo o afiliado, melhorar as mudanças de sua comunidade, fundamentado em prioridades identificadas entre eles, engajando-os inclusive como pesquisadores. Desta maneira, as mudanças estarão habilitadas a criar e manter ambientes mais fortalecidos, que satisfaçam aspectos e necessidades em ambos, no individual e no comunitário, e que são desfrutados tanto para se divertir como para brincar.

As discussões tratadas nesta pesquisa sobre participação, em sua maioria foram embasadas na literatura americana, contudo, teve especial cautela com as adaptações de seus métodos e modelos para o estudo de caso.

Contribuiu para o exercício de aumentar o alcance e a abrangência nas diferenças que se estabelecem de interação entre pobreza, favelização e questões cruciais que se pretende mitigar, enfatizando vantagens, pontuado desperdícios e delineando outras questões que não levam muito longe.

Apresentou considerações, procedimentos e métodos para processos participativos, procurando ampliar a competência do arquiteto como cidadão e como profissional capaz de entender e atender às necessidades prementes, não apenas de sobrevivência dos de poucos recursos. Levou-se em conta a pouca informação do arquiteto como cidadão, e sua formação acadêmica deficiente, construída sem contemplar segmentos da cidade ou grupo de pessoas marginalizadas em uma sociedade sectária.

Identificaram-se as dimensões múltiplas existentes nas relações que se estabelecem num processo participativo e que ofereceram tantas interpretações. Aguçando o olhar em direção a uma valorização e colaboração de comunidades populares no reconhecimento das suas questões prioritárias, na definição de soluções, mediando o que é possível e o que é ideal, dando melhores condições à sociedade de desenvolver suas habilidades em atingir objetivos maiores.

Concordando com Demo, apesar dos avanços no espaço político, a teoria sem a devida prática significa que as políticas sociais públicas têm como conteúdo típico, ainda que não exclusivo, a produção sagaz do controle social e da desmobilização popular, e, a prática participativa serve facilmente como manobra e manipulação populista.

Os comentários alcançados nesta pesquisa foram superficiais, o tema mostrou que a diversidade nas demandas de práticas participativas é muito grande e que, portanto, exige 
continuidade em outros estudos. Enquanto arquiteta vislumbrando um alcance maior ao meu papel social; as experiências no campo têm revelado meus preconceitos mais que qualquer coisa. Com este estudo minha intenção foi abrir um debate justo e pragmático. Uma força está ocorrendo, em que de um olhar que antes se chocava quando algo não seguia uma ordem anteriormente aprendida, para uma mobilização de interesses comuns, prometendo outras direções e expandindo o campo de atuação. Agora, certamente muda a natureza de nossa perícia e toca a arquitetura como um todo.

O que pretendeu esta pesquisa foi o de procurar entender, se é possível entender, onde estavam os nós de um entendimento que falava da participação, que colocava e coloca a necessidade da sustentabilidade das ações empreendidas e depois se afasta das discussões com a comunidade, menosprezando o saber popular e seus anseios mais declarados comprometendo assim os investimentos aplicados.

Finalizando, concordamos com um dos filósofos da educação, Anísio Teixeira, quando afirma que o mundo em transformação requer um novo tipo de homem consciente e bem preparado para resolver suas próprias questões, acompanhando a tríplice revolução da vida atual: intelectual, pelo incremento das ciências ${ }^{24}$, industrial, pela tecnologia, e social, pela democracia. Essa concepção exige "uma educação em mudança permanente, em permanente reconstrução".

\footnotetext{
${ }^{24}$ Ciência: o sentido proposto por Morin, sem desvinculá-lo do espiritual.
} 


\section{Bibliografia}

A epopéia de Gilgamesh. São Paulo: Editora Martins Fontes.

ABDEL-AZEEM, Atef (1996). A User participation intervention in the housing process. Tese de Doutorado. Cairo Egito: Al-Azhar University, Faculty of Engineering, Department of Architecture.

ALEXANDER, C. (1976). Urbanismo e participacion: el caso de la Universidad de Oregón. Barcelona: Editorial Gustav Gili.

ALEXANDER, C. (1985). The production of houses. New York: Oxford University Press. ALINSKY, S. (1972). Rules for radicals. New York: Vantage Books.

ALVA, Eduardo N. (1997). Metrópeles (In) Sustentáveis. Rio de Janeiro: Relume Dumará. APPLEYARD, D. (1981) Livable streets. Berkley: University of Califórnia Press

ARANTES, Otília; VAINER, Carlos; MARICATO, Ermínia (2000) A cidade de pensamento único: desmanchando consensos. Rio de Janeiro: Ed. Vozes

ARNSTEIN, Sherry R. (1969). A ladder of citizen participation. American Institute of Planners Journal. 35:215-224.

ARTIGAS, João B. Vilanova (1989). Função social do arquiteto. São Paulo: Nobel Editora.

AZEVEDO, Thales (1955). Povoamento da cidade do Salvador. 2 ${ }^{\text {a }}$.Ed. São Paulo: Companhia Editora Nacional. Biblioteca Pedagógica Brasileira. Série V. Brasiliana. Volume 281.

BACELAR, Gastão (1993). A poética do espaço. São Paulo: Martins Fontes

BACELAR, Telma M. S. (1986). Estado, planejamento participativo e a urbanização de favelas, na região metropolitana do Recife. Dissertação de mestrado apresentada à Universidade Federal de Pernambuco.

BEHESTI, M. R. (1986). The function of the design coalition team. In Design Studies vol7; number 3; July

BELL, Colin; NEWBY, Howard (1972). Community studies. New Yor: Praeger Publishers.

BESSIS, S. (1995). From Social exclusion to social cohesion: towards a policy agenda. In The Roskilde Symposium. University of Roskilde, Denamark. UNESCO

BONDUKI, N. (1988). Criando territórios de utopia: a luta pela gestão popular em projetos habitacionais. Dissertação de mestrado da Faculdade de Arquitetura da Universidade de São Paulo. 
BONDUKI, N. (1998). Origens da habitação social no Brasil, lei do inquilinato e difusão da casa própria. São Paulo: Estação Liberdade.

BORDENAVE, J. D. 1994. O que é participação. São Paulo: Editora Brasiliense. Coleção Primeiros Passos.

BOS, Alexander (1986). Desafios para uma pedagogia social. São Paulo: Editora Antroposófica.

BRANDÃO, Carlos E, (1999). O trabalho do saber. Porto Alegre: Editora Sulina.

BRANDÃO, Maria A. (1978). Origens da expansão periférica de Salvador. (mimeo)

BRANDÃO, Maria A. (1996). Morrer de morar: os caminhos da natureza nas cidades brasileiras. Salvador (mimeo)

BUENO, Laura M. M. (2000). Projeto e Favela: Metodologia para projetos de urbanização. Tese de doutorado apresentada à Faculdade de Arquitetura da Universidade de São Paulo.

BRASIL. Lei n. 9795 - 27 de abril de 1999. Dispõe sobre a Educação Ambiental. Política Nacional de Educação Ambiental.

BRASIL (1994). Constituição da República Federativa do Brasil. Brasília: Ibama

BRYSON, J. M. (1988). Strategic planning for public and nonprofit organizations. San Francisco: Jossey-Bass.

BOURDIEU, Pierre (2002). Um saber comprometido. Jornal Le Monde Diplomatique, edição portuguesa n. 35 .

BURNS, J. (1979). Connections: ways to discover \& realize community potentials. New York: McGraw Hill.

CALVINO, Ítalo (1997). Cidades invisíveis. São Paulo: Companhia das Letras.

CAPRA, Fritjof (1988). Sabedoria incomum. São Paulo: Cultrix.

CAPRA, Fritjof (2002). As conexões ocultas. São Paulo: Cultrix Amana-Key.

CARNEIRO, Edson (1980). A cidade de Salvador 1549: uma reconstituição histórica. $2^{\mathrm{a}}$.ed. Rio de Janeiro: Editora Civilização Brasileira.

CARR, Stephen; FRANCIS, Mark; STONE, Andrew: RIVLIN, Leanne (1992). Public space. New York: Cambridge University Press 
CARDOSO, Ruth (1994). A trajetória dos movimentos sociais. In Anos 90: Política Sociedade no Brasil. DAGNINO, E. (org). São Paulo: Editora Brasiliense.

CARVALHO, Maria A. A. (1991). Participação social no Brasil hoje. Instituto Polis. www.polis.org.br

CASTELLS, M. (1983). The City and the Grassroots. Berkeley: University of California Press.

CASTEL, Robert (1998). As metamorfoses da Questão Social. São Paulo: EDUC

CLAVAL, P. (1979). Espaço e poder. Rio de Janeiro: Editora Cortez.

COIMBRA, Ávila (2002). O Outro Lado do Meio Ambiente. Campinas, SP: Millenium Editora.

COMERIO, M. (1984). Community design: Idealism and entrepreneurship. In Participatory design: Theroy and techniques. Raleigh: Bookmasters, Inc.

Conferência das Nações Unidas sobre Meio Ambiente e Desenvolvimento (1993). Rio de Janeiro. Agenda 21: resumo. Centro de Informações das Nações Unidas no Brasil - São Paulo: Secretaria do Meio Ambiente.

CONNOLLY, W.E. (1969). The Bias of Pluralism. New York: Atherton Press.

CONNOR, D. M. \& ORENTEIN, S.G. (1995). Combining conflict resolution and public participation for challenging cases: The bridges of Winnipeg case. Consensus. October.

CULLEN, Gordon (1961). Townscape. London: Architetural Press.

DAGNINO, Evelina orgs. (2002). Sociedade civil, Espaços públicos e a Construção democrática no Brasil: Limites e possibilidades. In Sociedade civil e espaços públicos. Rio de Janeiro: Paz e Terra.

DAVIDOFF, Paul. (1965). Advocacy \& pluralism in planning. In Journal of the American Institute of Planners 31:331-38.

DELLA TORRE, Maria B. (1976). O homem e a sociedade. São Paulo: Cia Editora Nacional.

DEMO, Pedro (1988) Participação é conquista São Paulo: Editora Cortez

DEMO, Pedro (1996). Pobreza política. Campinas, São Paulo: Editora Autores Associados.

DEMO, Pedro (1998). O charme da exclusão social. Campinas, São Paulo: Editores Associados.

DEMO, Pedro (2001) Cidadania Pequena. São Paulo: Editora Autores Associados. 
Os desafios da cidade informal (1995). Seminário internacional. Belo Horizonte: Documentos finais do evento preparatório da II Conferência Habitat II

DIEGUES, A. C. (1996) O mito da natureza intocada. São Paulo: Hucitec.

Direito do Meio Ambiente e Participação Popular (1996) Série Estudos Educação Ambiental. Ibama \& MMA Brasília

DOIMO, A. Maria (1995). A voz e a vez do popular. Movimentos Sociais e participação política no Brasil pós 70. Rio de Janeiro: Relume-Dumará.

DURAND, Gilbert (1994) O Imaginário. In Ensaios sobre as ciências e a filosofia da imagem. Paris: Hatier.

DURAND, Gilbert (1993) A imaginação simbólica. São Paulo: Editora Cultrix.

Educação Ambiental: As grandes Orientações da Conferência de Tbilisi (1998). Série Estudos Educação Ambiental. Coleção Meio Ambiente: Ibama MMA Brasília.

EL-DIN RASHED, Ahmed Yehia (1994). Public participation in the conservation of historical environment: a case study of Luxor City, Egypt. London: Dissertação de doutorado apresentada à University of York.

ELIAS, Norbert (1987) Sociedade dos Indivíduos. Rio de Janeiro: Jorge Zahar Editores.

EPUCS (1976). Uma experiência de planejamento urbano. Salvador: PLANDURB

FELLET, José Carlos; CASTRO, Tereza I. L. (2002). Uma ameaça chamada Canudos. www.nethist.com//hb//20/hb01.shtml

FERNANDES, Ana, ; GOMES, M. A. (1990). Idealizações urbanas e a construção de Salvador moderna: 1859-1920. In Cidade \& História: Modernizações das Cidades Brasileiras. Salvador, Bahia: Editora da UFBa

FRANCO, Maria S. (1969). Homens livres na ordem escravocrata. São Paulo: Publicação do Instituto de Estudos Brasileiros.

FREIRE, Paulo (1979). Educação e mudança. São Paulo: Editora Paz e Terra.

FREIRE, Paulo. (1990). Pedagogy of the Oppressed. New York: Continuum Publications.

FREIRE, Paulo \& HOURTON, Myles (1990). We make the road by walking: conversation on education and social change. Philadelphia: Temple University Press.

FREIRE, Paulo; NOGUEIRA, A.; MAZZA, D. (1995). Fazendo escola conhecendo a vida. São Paulo: Papirus Editora.

FREIRE, Paulo (1996).Pedagogia da autonomia. Rio da Janeiro: Editora Paz e Terra. 
FRIEDMANN, J. (1992). Empowerment: The Politics of Alternative Development. Cambridge, MA: Blackwell.

FROMM, D. (1991). Collaborative Communities. New York: Van Nostrand Reinhold.

GEE, Marie (1994). Public Space in Journal of Environmental Psychology 14, pp 113-124

GIBSON, T. (1988). Planning for Real: Users' Guide. Telford, UK: Neighborhood Initiatives Foundation.

GOHN, Maria da Glória (2001). Movimentos Sociais e Educação. São Paulo: Editora Cortez.

GOHN, Maria da Glória (2003). Movimentos Sociais no Início do Século XXI. Rio de Janeiro: Editora Vozes.

GOODMAN, R. (1971). After the Planners. New York: Simon \& Schuster.

GORDILHO, Walter (1960). Contribuição ao estudo da evolução urbana da cidade de Salvador, et al. In Coleção Estudos Baianos No. 01 - Cidade de Salvador. Aspectos Geográficos, históricos, sociais e antropológicos. Salvador: Imprensa Oficial da Bahia.

Habitat (2000). Global Trend Report on Human Settlements. http://www.uncs.org 16 de dezembro de 2001

HABITAT BRASIL/BID (1999). Manual de Procedimentos para Elaboração de projetos integrados de intervenção em área subnormal. Ministério de Planejamento do Governo Federal.

HABRAKEN, N. J. (1986). Towards a new professional role. In Design Studies 7, 3:102-8.

HALPRIN, L. \& BURNS, J. (1974).Taking part: a workshop approach to collective creativity. Cambridge: MIT Press.

HAMDI, N. (1991). Housing without houses: participation, flexibility, enablement. New York: Van Nostrand Reinhold.

HART, R. (1979). Children's Experience of Place. New York: Irvington Publishers.

HATCH, R. (1984). The Scope of Social Architecture. New York: Van Nostrand Reinhold.

HESTER, R. T. Jr. (1987). Making the grassroots whole. In Built Environment 13,1:45-60.

HESTER, R. T. Jr. (1990). Community design primer. Mendocino, CA: Ridge Times Press.

HOUGH, Michael (1995). Cities and Natural Process. Rutledge: New York

JONES, B. (1990). Neighborhood planning: a guide for citizens and planners. Chicago, Ilinois: American Planning Association. 
JONES, Stanton (1999). Participation and community at the landscape scale. In Landscape Journal Venda18 no.1 Spring.

KHALLIL, Husam, (1989). User participation in evaluating an urban open space. Tese de mestrado em arquitetura apresentada à Jordan University Housing Scheme.

KOWARICK, Lúcio (1994). As lutas sociais e a cidade. São Paulo: Paz e Terra.

KOWARCIK, Lúcio (1993). A Espoliação urbana. São Paulo: Paz e Terra.

KOWARCIK, Lúcio (2000). Escritos urbanos. São Paulo: Editora 34..

LACEY, Hugh (1998). Valores e atividade científica. São Paulo: Discurso Editorial

LEMOS, Carlos (1998). Os primeiros cortiços paulistanos. In Habitação e cidade. São Paulo: Editora da USP.

LYNCH, Kevin (1960). The image of the city. Cambridge: MIT Press.

LYNCH, Kevin (1978). The managing the sense of a region. Cambridge: The MIT Press.

LYNCH, Kevin (1991). City sense and city design. Cambirdge: The MIT Press.

MARSHALL, T.H. (1967). Cidadania, classe social e status. Rio de Janeiro: Zahar Editores

MAGNANI, José Guilherme e TORRES, L. (org) (1996). Na metrópole: textos de antropologia urbana. São Paulo: EdUSP.

MARICATO, Hermínia (1997). Habitação e cidade. São Paulo: Atual Editora.

MATHEY, Kosta (1992). Beyond self-help housing. London: Mamsell Publishing Limited.

MATTEDI, Maria (1978). As invasões em Salvador. Dissertação no Mestrado na Faculdade de Filosofia Ciências Humanas da Universidade Federal da Bahia.

MOORE, R. \& WONG, H. (1998). Natural learning: creating environments for rediscovering nature's way of teaching. Berkeley, CA: MIG Communications.

MORIN, Edgard (1977). O método I, a natureza da natureza. Lisboa: Publicações EuropaAmérica.

MORIN, Edgard (1986). O método: o conhecimento do conhecimento. Publicações EuropaAmérica.

MORAES, Antonio (1994). Meio ambiente e ciências humanas. Hucitec: São Paulo

MOUDON, Anne (1987). Public Streets for public use. New York: Van Nostrand Reinhold Company. 
MOURA, Maria L. S.; FERREIRA, Maria C.; PAINE, Patrícia (1998). Manual de elaboração de projetos de pesquisa. Rio de Janeiro: Editora UFRJ.

PATTON, C.V,(1988). Spontaneous shelter. Philadelphia: Temple University Press

PHLIPPI JUNIOR, Arlindo; ROMÉRO, Marcelo \& BRUNA, Gilda Collet (2004). Curso de Gestão Ambiental. São Paulo: Editora Manole.

POISTER, T.H. \& STREIB, G. (1989). Management tools in municipal government: trends over the past decade. Public Administration Review, 49:244.

Primeiro Seminário de Imagem de Salvador (1984). Prefeitura Municipal do Salvador. Salvador: Impresso na Gráfica Econômico.

PRO-MORADIA -Trabalho Social trechos Normativos que tratam especificamente da Participação da Comunidade. Resolução no. 181, de 05 de junho de 1995 e Instrução Normativa no. 02 de 23 de junho de 1995

PUTNAM, Robert (2002). Comunidade e democracia. São Paulo: Blumen.

RAMASUBRAMANIAM, L. (1994). Integrating theory, method, and knowledge: Strategies for improving research utilization. Unpublished paper: UWM, Milwaukee.

RAPOPORT, AMOS. (1982). The meaning of the built environment. Beverly Hills: Sage Publications.

RED Rockers. (1973). Shelter. Bolinas, CA: Shelter Publications.

REGINO, Tássia M. (coord) (2001). Projeto de trabalho de participação comunitária do projeto de recuperação ambiental e remanejamento de ocupações irregulares do Cerro Lago e Jardim Branca Flor - Itapecirica da Serra, São Paulo. HABITAR-BRASIL/BID

REICH, Y.; KONDA, S.; MONARCHI,I; LEVY,S. (1996) Varieties and issues of participation and design. In Design Studies Journal Vol17 no.2 abril1996. Grã-Bretanha.

RESCHER, N. (1993). Pluralism: against the demand for consensus. Oxford: Clarendon Press.

RIBEIRO, Wagner Costa (2001). A ordem ambiental internacional. São Paulo: Contexto Acadêmica.

RIGHETTO, Antonio Marozzi (1999). Hidrologia e recursos hídricos. São Carlos: EESC Universidade de São Paulo

ROCHA, João A. L. (org) (1992). Anísio em movimento: a vida e as lutas de Anísio Teixeira pela escola pública e pela cultura no Brasil. Salvador: Fundação Anísio Teixeira.

SANTOS, M. (1982). Ensaios sobre a urbanização Latino Americana. 1ª. Ed. São Paulo: Hucitec. 
SANTOS, M. (1987). Espaço do cidadão. São Paulo: Livraria Nobel.

SANTOS, M. (1997). Pensando o espaço do homem. São Paulo: Hucitec.

SANOFF, H. (1978). Designing with community participation. New York: McGraw Hill.

SANOFF, H. (1979). Design games. Los Altos, CA: William Kaufmann.

SANOFF, H. (1981). Human exchange techniques for citizen participation in town revitalization. In Design Studies 2,3: 157-164.

SANOFF, H. (1990). Participatory design: theory and techniques. Raleigh: School of Design, North Carolina State University.

SANOFF,H. (2000). Community participation methods in design and planning. New York: John Wiley \& Sons, Inc.

SANTOS, Carlos Nelson (1984). Formações metropolitanas no Brasil, mecanismos estruturantes. Tese de doutorado na Faculdade de Arquitetura e Urbanismo da Universidade de São Paulo.

SANTOS, Carlos Nelson (1988). Quando a Rua Vira Casa: a apropriação de espaços de uso coletivo em um centro de bairro. Rio de Janeiro Centro de Pesquisas Urbanas IBAM.

SCHAMA, Simon (1995). Paisagem e memória. São Paulo: Companhia das Letras.

SELTZ, R. (1975) Métodos de pesquisa nas relações sociais. Editora da Universidade de São Paulo: São Paulo

SILVA, Pedro L.B. (1999). Programa de Apoio a Gestão Social no Brasil.

Subcomponente: Desenho e Implantação de Estratégia de Avaliação Modelos de Avaliação de Programas Sociais. NEPP - Núcleo de Estudos de Políticas Públicas da UNICAMP: Campinas. Ministério do Planejamento.

SILVA, Alberto Gomes (1999). Parâmetros técnicos para urbanização de favelas. FUPAM/LABHAB/FAUUSP/-FINEP/CEF.

SOMMER, R. (1983). Social design. New Jersey: Prentice Hall, Inc.

SOUZA, Ângela M. G. (1990). Invasões e intervenções públicas: uma política de atribuição espacial em Salvador: 1946-1989. Tese de mestrado em arquitetura apresentada à Universidade Federal do Rio de Janeiro

SOUZA, Ângela M. G. (2000). Limites do habitar: segregação e exclusão na configuração urbana contemporânea de Salvador e perspectivas no final do século $\mathrm{XX}$. Salvador: Editora da UFBa. 
SOUZA, Boaventura (2003). O papel da produção de conhecimento na transformação social. In Conferência Internacional sobre o Papel da Sociedade Civil nas pautas políticas. São Paulo: Fundação Getúlio Vargas.

SOUZA, Jessé (2000). A modernização seletiva. Brasília: Editora UNB.

SOUZA, Jessé (2003). A construção social da subcidadania para uma sociologia política da modernidade periférica. Belo Horizonte, Minas Gerais: Editora UFMG.

SPIRN, Anne Whiston (1995). O jardim de granito. São Paulo: EDUSP.

SPOSATI, Aldaíza (1988). Vida urbana e gestão da pobreza. São Paulo: Cortez Editora.

TAVARES, Luís H. D. (1974). História da Bahia. Salvador: Editora da UFBa.

THOMAS, R.L.; MEANS, M.C. \& GRIEVE, M.A. (1988). Taking Charge: How Communities are Planning their Futures. Washington, DC: International City Management Association.

TEIXEIRA, Elenaldo (2000). O local e o global. Limites da participação cidadã. São Paulo: Cortez Editora.

TEIXEIRA, Elenaldo (2002). Sociedade civil e participação cidadã no poder local. Salvador, Bahia: Editora Universidade Federal da Bahia.

TEIXEIRA, Maria Cecília (2001). Conferência do Imaginário e das Representações Sociais da Educação Física, Esporte e Lazer. São Paulo: USP

THOMAS, Keith (1983). O homem e mundo natural. São Paulo: Cia das Letras.

TJOSVOLD, D. (1993). Learning to manage conflict: getting people to work together productively. New York: Lexington Books.

TORO, José Bernardo; WERNECK, Nísia M. (1997). Mobilização social um modo de construir a democracia e a participação. Brasília: Ministério do Meio Ambiente, Recursos Hídricos e Amazônia Legal.

TURNER, J. F. C. (1977). Housing by People. New York: Pantheon.

TURNER, J.F.C., FICHTER, Robert (1972). Freedom to build. New York: The Macmillan Company

United Nations for Human Settlements (Habitat-1984), Community Participation in the Execution of Low-Income Housing Projects, Nairobi, Kenya p.6.

VALENZUELA, Pep; TAFALLA, Joan (2001). Democracia participativa en Brasil. Espanha: Revista EI Viejo TOPO.

VAZ, Lílian F. (1998). Do cortiço a favela. In Habitação e Cidade. São Paulo: Editora da FAUUSP. 
VIRILO, Paulo (1993). O Espaço crítico e as perspectivas do tempo real. Rio de Janeiro: Editora 34.

WATES, N. (1997). Action planning. London: Prince of Wales’s Institute of Architecture.

WATES, N. \& KNEVITT, C. (1987). Community architecture: how people are creating their own environment. London: Penguin.

WILSON, Colin (1988). Rudolf Steiner: o homem e sua visão. São Paulo: Martins Fontes.

WHITE, S.A.; NAIR, K.S. \& ASCROFT, J. (1994). Participatory communication: working for change and development. Thousand Oaks, CA: Sage Publications.

WHYTE, W.F. (1991). Participatory action research. Newbury Park, CA: Sage Publications.

WULZ, F. (1986). The concept of participation. In Design Studies 7, 3:153-62.

ZALUAR, Alba (1994). A máquina e a revolta: as organizações populares e a pobreza. São Paulo: Editora Brasiliense.

ZUCKER, C. (1995). The importance of interdisciplinary teamwork. In Urban Design Symposium. Washington, DC: Library of Congress.

\section{LEITURA ADICIONAL}

ALESHIRE, R.A. (1970). Planning and citizen participation: costs, benefits and approaches. In Urban Affairs Quarterly 5. 6:369-93.

ALEXANDER, C. (1975). The Oregon experiment. New York: Oxford University Press.

ALEXANDER, C. (1979). The timeless way of building. New York: Oxford Press.

ALEXANDER, C. (1981). The Linz Cafe. New York: Oxford University Press.

ALTSCHULER, A.A. (1970). Community control. Indianapolis: Bobbs-Merrill.

ANTUNES, Maria C. A. (1994). Arquitetura participativa - o papel do arquiteto no processo participativo de organização do espaço urbano e de moradia. Dissertação de mestrado apresentado a Faculdade de Arquitetura da USP.

AMARAL, Ângela A. C. (2001). Habitação, participação popular e cidadania. Dissertação de mestrado apresentada à Faculdade de Arquitetura da USP.

AQUINO, Luiz C. A. (1996). Movimento pro-participação popular na constituição municipal de São José dos Campos. Dissertação de mestrado apresentada a Faculdade de Filosofia Letras e Ciências Humanas da USP. 
BARTOLO, Fernando A. (2003). Empresa de participação comunitária aspectos teóricos e práticos. Tese de mestrado apresentada à ESALQ.

BIENENSTEIN, Regina (2001). Redesenho urbanístico e participação social em processo de regularização fundiária. Tese de doutorado apresentada a Faculdade de Arquitetura da USP.

BIAGI, R. (1978). Working together: a manual for helping groups work effectively. University of Massachusetts Citizen Involvement Training Project.

BLUMBERG, P. (1969). Industrial democracy: the sociology of participation. New York: Schoken Books.

BRANDÃO, C. R. (1995). Em campo aberto: escritos sobre educação e a cultura popular. São Paulo: Editora Cortez.

BURKE, E.M. (1968). Citizens participation strategies. In Journal of the American Institute of Planners 34, 5:287-94.

BURKE, E.M. (1969). Citizen participation is necessity: How can we make it work. In Journal of Housing 26, 12:599-602.

BURNS, J. (1979). Citizens take part in the process of urban design. In Nations Citizen's Weekly 2, 43.

CALDERÓN, Adolfo (1999). Democracia local e participação popular. São Paulo: Editora Cortez.

CALIARI, Rogério O. (2002). Pedagogia alternativa e desenvolvimento local. Tese de mestrado apresentada à Universidade Federal de Lavras.

CANTAGALO, M. (2005). A experiência da participação popular no processo de urbanização de um bairro da cidade de Americana/SP. Um estudo a respeito da organização popular, gestão pública e emancipação social. Simpósio Internacional de Iniciação Científica da Universidade de São Paulo. http://www.usp.siicusp

COMERIO, M. C. (1987). Design and empowerment: Twenty years of community architecture. In Built Environment 13, 1:15-28.

CONNOR, D.M. (1988). A new ladder of citizen participation. In National Civic Review, 77,3:249-257.

DALE, D. (1978). How to make citizen involvement work. University of Massachusetts: citizen involvement training project. DAMER, S. \& HAGUE, C. (1971). Public participation in planning. In Town Planning Review 42, 3, 7:217-32.

DELORS, Jacques ( 1999). Educação: um tesouro a descobrir. São Paulo: 2a. ed, Editora Cortez. 
DEMO, Pedro (1999). Conhecimento moderno: sobre ética e intervenção do conhecimento. Rio de Janeiro: Editora Vozes.

DEVEREUX, E.C. Jr. (1960). Community participation and leadership. In Journal of Social Issues 16:29-45

DRAPER, T.A.( 1971). Citizen Participation. Toronto: New Press.

ERSKINE, R. (1976). Designing with user participation. In RIBA Journal 84:273

FANNING, O. (1975). Man and his environment: citizen action. New York: Harper and Row.75.

FRIEDMANN, J. (1973). The public interest and community interest. In Journal of American Institute of Planners 39, 1, 2:4-7.

GIBSON, T. (1986). Us plus them: how to use the experts to get what people really want. London: Town and Country Planning Association.

GITTEL, M. (1980). Limits to citizen participation. Beverly Hills: Sage Publications.

GODSCHALK, D. (1972). Participation, planning and exchange in old and new communities: a collaborative paradigm. Chapel Hill: University of North Carolina.

HABRAKEN, N. J. 1972. Supports: an alternative to mass housing. New York: Praeger Publishers.

HALPRIN, L. (1969). The RSVP cycles: processes in the human environment. New York: Braziller, Inc.

HAMDI, N. \& GREENSTREET, B.(1981). Participation in housing, Working Papers No. 57 and 58. Oxford Polytechnic: Department of Town Planning.

KOGA, Dirce (2003). Medidas de cidades. São Paulo: Editora Cortez.

KROLL, Lucien. (1986). The architecture of complexity. London: Batsford.

LAWRENCE R. (1987). Basic principles for public participation in house planning. In Design Studies 8, 2:139-143.

LEITE, Maria A. F. (1993). Natureza e participação social, uma nova estética. Artigo Periódico Revista do Instituto de Estudos.

LISK, F. (1985). Popular participation in planning for basic needs. Cambridge,UK: Cambridge University Press.

MacDONALD, D. (1997). Democratic architecture. New York: Whitney.

McLAGAN, Patrícia (2000). A nova era da participação: o desfio de emocionar e envolver pessoas. Rio de Janeiro: Editora Campus. 
MARCUS, C.C. \& SARKISSIAN, W. (1986). Housing as if people mattered: site guidelines for medium density family housing. Berkeley: University of California.

MIRANDA, Bianka A. (1997). Em busca da participação popular: a política habitacional da gestão Erunidina (1989-1992). Tese de mestrado apresentada à Faculdade de Filosofia Letras e Ciência Humanas da USP.

MORIN, Edgar (2002). Os sete sabers e outros ensaios. São Paulo: Editora Cortez.

NEGRELOS, Eulalia P. (1998).Remodelação de bairros populares em São Paulo e Madrid 1976-1992: projeto e participação popular. Dissertação de mestrado apresentada à Faculdade de Arquitetura e Urbanismo da USP.

PECHMAN, R. M. (1994). Olhares sobre a cidade. Rio de Janeiro: Editora UFRJ.

PEREIRA, Raul (1975). Habitação popular e participação social. Artigo na biblioteca da FAU.

SANTOS, M. (2002). O país distorcido. São Paulo: Publifolha

SORRENTINO, M. (1998). Participação $\mathrm{x}$ instrumentalização. In Informativo da Associação de Engenharia Sanitária e Ambiental. V.2 no. 18 Junho de 1998.

SUSSKIND, L.; McKEARMAN, S.; THOMAS-LARMER, J.(2000). Consensus building handbook: a comprehensive guide to reaching agreement. Consensus Building InstituteCBI.

WATES, N. \& WOLMAR, C. (1980). Squatting: the real story. London: Bay Leaf.

WOOLEY, T. (1988). Ten topics for participators. In Open House International 13,3.

ZEISEL, J. (1972). Fundamental values in planning with the non-paying client. In Architecture \& Human behavior, edited by C. Burnette. Philadelphia: American Institute of Architects. 


\section{Anexos}

\section{PRÓ-MORADIA - TRABALHO SOCIAL}

TRECHOS DOS NORMATIVOS QUE TRATAM ESPECIFICAMENTE DA PARTICIPAÇÃO DA COMUNIDADE

1) As Resoluções são aquelas aprovadas pelo Conselho Curador do FGTS

2) As Instruções Normativas são aquelas editadas pelo Gestor da Aplicação, que até 1999 era o Ministério do Planejamento e Orçamento

\section{RESOLUÇÃO Nº- 181, DE 05 DE JUNHO DE 1995 (REVOGADA)}

\section{4 \\ PRÉ-REQUISITOS PARA PARTICIPACÃO NO PROGRAMA}

Constituem-se em pré-requisitos básicos para a contratação de recursos através do PRÓ-MORADIA, sem prejuízo das demais regras estabelecidas nesta Resolução e nos instrumentos normativos em vigor, os abaixo discriminados:

a) a predefinição das famílias a serem atendidas;

b) a participação das famílias a serem atendidas, na definição e acompanhamento do projeto do qual serão beneficiárias;

c).........

\section{INSTRUÇÃO NORMATIVA Nº 02, DE 23 DE JUNHO DE 1995 (REVOGADA}

IV Para a finalidade de enquadramento das propostas nos pré-requisitos definidos no item 4 do Anexo I da Resolução $n^{\circ}$ 181, serão aplicados os seguintes critérios:

a) alínea "a”: a pré-definição das famílias a serem atendidas pelo empreendimento proposto, deverá embasar-se em cadastramento e seleção dos beneficiários, que leve em consideração a renda familiar, a idade do chefe da família e o número de dependentes, bem como outros parâmetros objetivos, previamente definidos, a critério do proponente;

a.1) no caso de intervenção em área ocupada, dispensa-se a seleção do universo dos beneficiários na forma acima disposta, prevalecendo o cadastro das famílias;

b) alínea "b": a comprovação da participação das famílias a serem atendidas, na definição e acompanhamento do projeto do qual serão beneficiárias, dar-se á através de apresentação de projeto de desenvolvimento de trabalho social, a ser desenvolvido diretamente pelo Mutuário ou por meio de equipe técnica especializada contratada, com as famílias beneficiárias, objetivando a mobilização da comunidade com vistas ao atendimento 
de suas necessidades e aspirações, através das seguintes atividades básicas, sem prejuízo de outras que venham a ser definidas pelo proponente:

b.1) colaborar na elaboração do projeto de forma a alcançar maior grau de atendimento às necessidades e aspirações da comunidade;

b.2) colaborar no acompanhamento da execução das obras, através da verificação de prazos, especificações, e outros itens componentes do projeto;

b.3) participação ativa da comunidade em alterações do projeto que, eventualmente, venham a se fazer necessárias;

b.4) desenvolvimento de atividades que visem a orientar a comunidade quanto ao uso da área objeto da intervenção, à adequada utilização das benfeitorias e serviços e à conscientização dos seus direitos e responsabilidades;

b.5) desenvolvimento de atividades específicas de educação sanitária, com vistas à correta apropriação e uso das benfeitorias implantadas;

b.6) estímulo à criação e atuação de bases organizacionais representativas da comunidade beneficiária, com vistas a sua própria promoção e desenvolvimento; 
RESOLUÇÃO Nº 215, DE 23 DE ABRIL DE 1996 (REVOGADA)

2 MODALIDADES

O PRÓ-MORADIA operará por intermédio das seguintes modalidades:

\section{HABITAÇÕES}

\subsection{URBANIZAÇÃO DE ÁREAS OCUPADAS POR SUB-}

Esta modalidade contempla intervenções necessárias à segurança, salubridade e habitabilidade de áreas ocupadas por favelas, mocambos, palafitas ou outros tipos de aglomerados habitacionais inadequados, abrangendo a mobilização da comunidade, a execução de obras e serviços de infra-estrutura, equipamentos comunitários, lotes urbanizados, a construção de habitações e melhorias habitacionais.

\subsubsection{A execução de lotes urbanizados e a construção de unidades} habitacionais está vinculada ao reassentamento de famílias residentes na área objeto da intervenção, decorrente da necessidade de alteração de seu desenho urbano.

\section{PRÉ-REQUISITOS PARA CONTRATAČ̃̃O NO PROGRAMA}

Constituem-se em pré-requisitos básicos para a contratação de recursos através do PRÓ-MORADIA, sem prejuízo das demais regras estabelecidas nesta Resolução e nos instrumentos normativos em vigor, os abaixo discriminados:

a) a identificação das famílias a serem atendidas;

b) a previsão da participação das famílias a serem atendidas, na elaboração do projeto e no acompanhamento de sua implantação;

\section{INSTRUÇÃO NORMATIVA Nº 12, DE 22 DE MAIO 1996 (REVOGADA)}

\section{DOS PRÉ-REQUISITOS PARA CONTRATAČ̃̃ NO}

PROGRAMA

Para fins de cumprimento dos pré-requisitos para contratação no Programa, previstos nas alíneas “a”, "b”, “c”, “d” e “e” do item 6 do Anexo I da Resolução no 215, será observado o disposto neste item.

1 Alínea “a” - A identificação das famílias a serem atendidas dar-se-á através da realização de cadastramento das mesmas, abordando sua situação sócio-econômica.

2 Alínea "b” - A previsão da participação das famílias a serem atendidas, na elaboração do projeto e no acompanhamento de sua implantação será comprovada através da apresentação de proposta de trabalho social, a ser desenvolvido pelo proponente, após a contratação, contendo as seguintes atividades básicas:

a) apresentação da proposta de intervenção às famílias envolvidas no sentido de obter sua participação em todas as etapas da mesma; 
b) desenvolvimento de atividades específicas de educação sanitária, bem como de atividades que objetivem, de maneira geral, orientar às famílias envolvidas quanto ao uso da área objeto da intervenção, à adequada utilização das benfeitorias e serviços e à conscientização dos seus direitos e responsabilidades;

c) estímulo à criação e atuação de bases organizacionais representativas das famílias beneficiárias, com vistas a sua própria promoção e desenvolvimento. 


\section{RESOLUÇÃO N 249, DE 10 DE DEZEMBRO DE 1996 (REVOGADA)}

\section{MODALIDADES}

O Programa operará por intermédio das seguintes modalidades:

\subsection{URBANIZAÇÃO DE ÁREAS}

Intervenções necessárias à segurança, salubridade e habitabilidade de população localizada em áreas inadequadas à moradia, visando a sua permanência ou realocação, através das seguintes ações: parcelamento de glebas, regularização fundiária, execução de obras e serviços de infra-estrutura e equipamentos comunitários, aquisição e/ou produção de lotes urbanizados, construção de habitações e melhorias habitacionais;

\section{INSTRUÇÃO NORMATIVA Nº 03, DE 9 DE JANEIRO DE 1997 (REVOGADA)}

\section{ENQUADRAMENTO DE PROPOSTAS}

O enquadramento de propostas, apresentadas no âmbito do Programa PRÓ-MORADIA, será realizado pelo Ministério do Planejamento e Orçamento, por intermédio da Secretaria de Política Urbana, ou, mediante convênio, pelas Instâncias Colegiadas Estaduais, de que trata a Portaria $\mathrm{n}^{\circ}$ 114, de 16 de junho de 1995, do Ministério do Planejamento e Orçamento, suas alterações e aditamentos, e observará os aspectos abaixo relacionados, sem prejuízo das normas gerais que regem as operações do Fundo de Garantia do Tempo de Serviço:

a) a proposta deverá conter informações sócio-econômicas, com ênfase ao perfil de renda, e das atuais condições habitacionais das famílias a serem atendidas, bem como caracterizar as obras e serviços a executar que deverão estar adequados às modalidades do programa;

b) a proposta deverá prever a realização de trabalho social, objetivando identificar as necessidades das famílias beneficiadas e orientá-las quanto ao correto uso e apropriação das benfeitorias realizadas, com ênfase à educação sanitária e ao exercício de seus direitos e obrigações; 


\section{RESOLUÇÃO No 290, DE 30 DE JUNHO DE 1998 (VIGENTE) \\ 1 OBJETIVO}

O PRÓ-MORADIA visa apoiar o poder público no desenvolvimento de ações integradas e articuladas com outras políticas setoriais, que resultem na melhoria da qualidade de vida da população de menor renda, através de alternativas habitacionais.

\section{INSTRUÇÃO NORMATIVA N 06, DE 03 DE JULHO DE 1998 (VIGENTE)}

\section{DIRETRIZES GERAIS}

As propostas apresentadas no âmbito do PRÓ-MORADIA observarão as seguintes diretrizes, além daquelas dispostas na Portaria ${ }^{\circ}$ 114, de 16 de junho de 1995, com a redação dada pelo item 1 do Anexo I da Portaria nº 35, de 16 de maio de 1996, do Ministério do Planejamento e Orçamento:

a) participação das famílias beneficiadas nos investimentos realizados;

\section{CRÉDITO}

\section{ENQUADRAMENTO DE PROPOSTAS DE OPERACÃ̃ DE}

âmbito do PRÓ-MORADIA, será realizado peso Ministerio do Planejamento e Orçament por intermédio da Secretaria de Política Urbana, ou, mediante convênio, pelas Instâncias Colegiadas Estaduais, de que trata a Portaria $\mathrm{n}^{\circ}$ 114, de 16 de junho de 1995, do Ministério do Planejamento e Orçamento, suas alterações e aditamentos, e observará os aspectos abaixo relacionados, sem prejuízo das normas gerais que regem as operações do Fundo de Garantia do Tempo de Serviço:

a) atendimento ao objetivo e modalidades do programa e observância das condições operacionais definidas no item 5 deste Anexo;

b) situação regular do proponente em relação ao FGTS;

c) verificação da existência de compatibilidade entre o valor de empréstimo solicitado e a capacidade de pagamento do proponente ao crédito.

3.1 Para fins de verificação do disposto na alínea “a” do caput deste item, a proposta deverá:

a) conter informações sócio-econômicas, com ênfase ao perfil de renda, e das atuais condições habitacionais das famílias a serem atendidas, bem como caracterizar as obras e serviços a executar que deverão estar adequados ao objetivo e modalidades do programa;

b) prever a realização de trabalho social, objetivando identificar as necessidades das famílias beneficiadas e orientá-las quanto ao correto uso e apropriação das benfeitorias realizadas, com ênfase à educação sanitária e ao exercício de seus direitos e obrigações. 
FIM! 


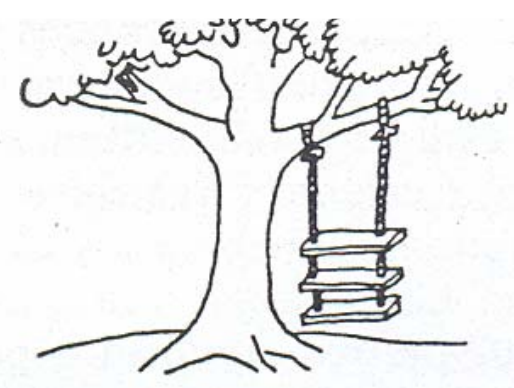

Tal como lo veía el promotor

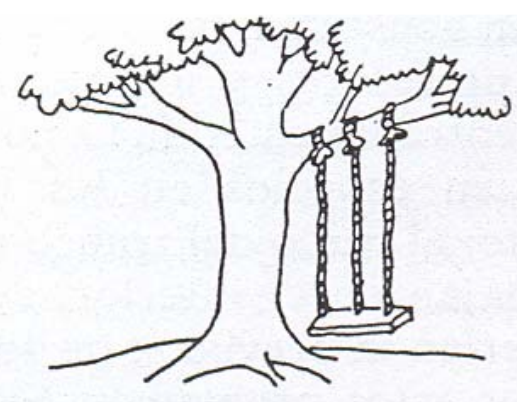

Cómo se especif, en la demanda del proyecto

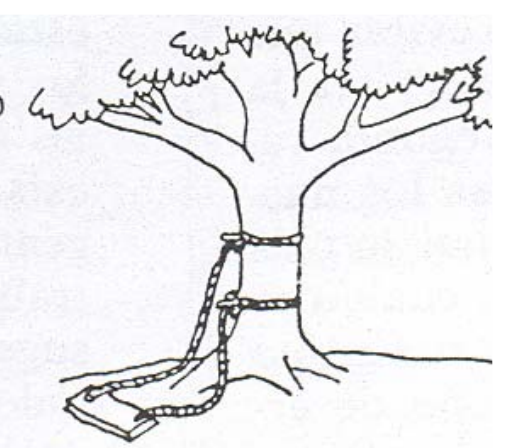

Tal como lo diseñó el analista

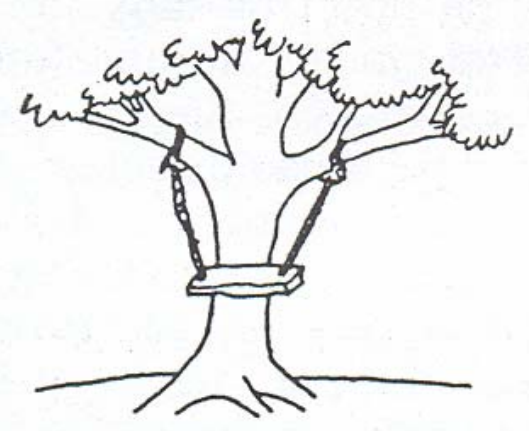

Tal como lo diseñaron los programadores

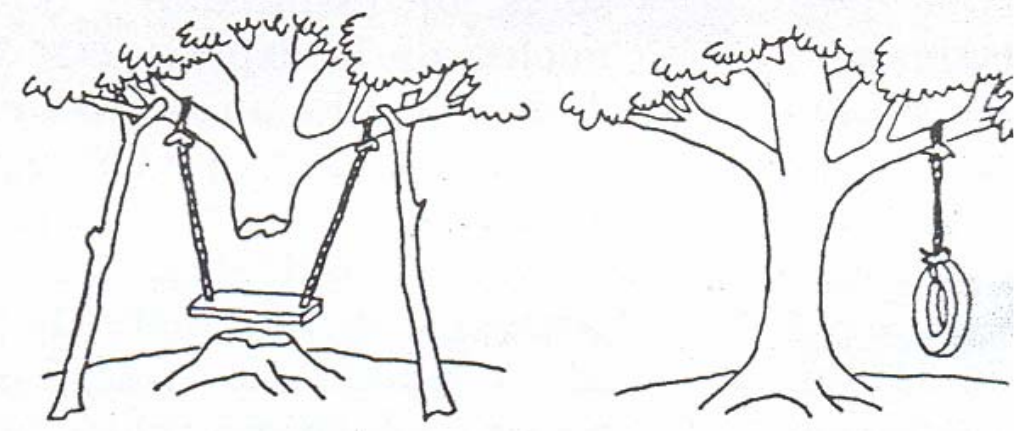

Tal como se instaló
Lo que el usuario quería 